
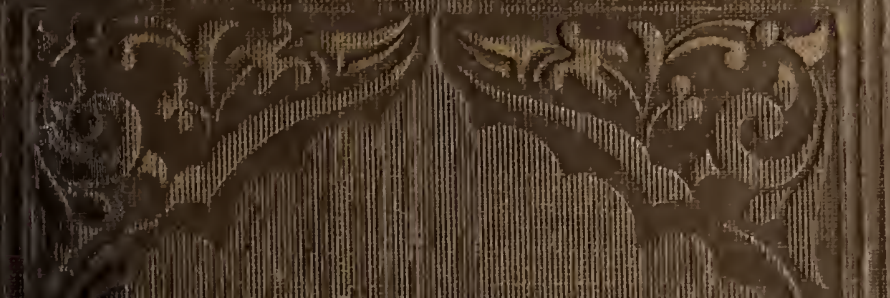

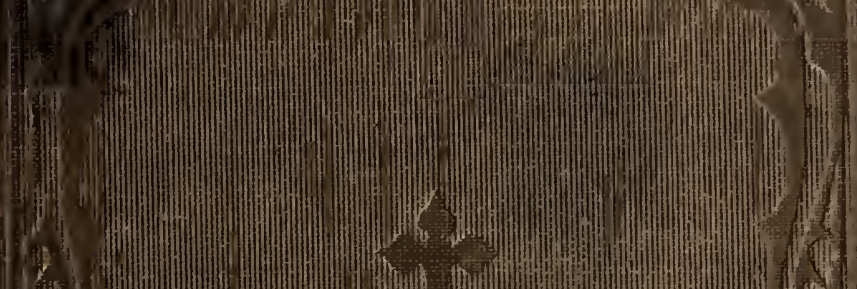
(1)

tho

MIil

II 
16 


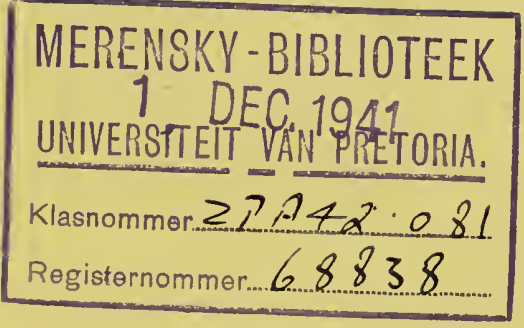





\title{
JOURNAL
}

OF

AN EXPEDITION

UP

\section{THE NIGER AND TSIIADDA RIVERS,}

\author{
UNDERTAKEN
}

Bx MaCgregor LaIrd, Esq.

x*

CONNECTION WITH THE BRITISH GOVERNMENT',

IN 1854 .

BY THE

REV. SAMUEL CROWTHER.

WITH MAP AND APPENDIX.

LONDON :

CHURCH MISSIONARY HOUSE, SALISBURY SQUARE; SEELEY, JACKSON, AND HALLIDAT, FLEET STREET.

MDCCCLV. 
T. C. JOHNS, PRINTER, Wine Office Court, Fleet Street. 


\title{
C ONTENTS.
}

\author{
CHAP. I.
}

DEPARTURE FROM ABBEOKUTA-EIBARKATION AT LAGOSARRIVAL AT FERNANDO PO-THE LATE MR. BEECROFTAIRIVAL AND DEPARTURE OF THE 'PIEIAD'-CROSSING THE BAR AT THE NUN-INDUSTRY IN THE DELTA-UNHEALTHINESS OF THE DELTA-PLOGRESS THROUGH THE DELTA-ABOH AND KING OBI-SIMON JONAS REMAINS AT ABOH-THE ATTA OF IDDA-AMA ABOKKO-DASABA-ARRIVAL AT THE CONFLUENCE . . . . . . P. 3

CHAP. II.

ENTRANCE OF THE TSHADIA-SINCERITY OF AMA-ABOKKOTHE FILATAS-DESTRUCTION OF PANDA-IYANPE-THE BASSA COUNTRY AND LANGUAGE-CONSULTATION ABOUT TURNING BACK - PASS DAGBO, THE TERMINATION OF FORMER EXPEDITIONS-DOMA-BLIND HEPORT OF TWO WHITE MEN IN THE NEIGHBOURHOOD-THE MITSHI TIIBE - ORIGIN OF THE CIARGE OF CANNIBALISM - IGARA TRADITION-DETENTION AT OJOGO-CHARACTER OF ZURI -KEANA AND ITS KING-ARRIVAL OFF ROGAN-KOTOSUSPICION OF THE NATIVES AT GANDIKO AND GANKERA REMOVED BY CONFIDENCE . . . . .

CHAP. III.

INTERTIEW WITH THE CIIEF OF ZHIBU-PROGRESS TO ZHIBU -DEGRADATION OF THE PEOPLE-DIFFICULTY IN PROCURINO FUEL-GUROWA-VISIT TO HAMARUWA-FAVOURABLE RLCEPTION BY THE KING-DESCIRTPION OF THE TOWN-ITS THADE-FAILURE OF WOOD FOR FUEL DETERHINATION TO PENETRATE THREE DAX' TOYAGE UIGHER IN THE BOAT-TUE STEAMER COMMENCES HER IEETURN-GROUNDS ON A MUD BANK-RETURN OF THE 7:OAT

CHAP. IV.

RETURN OF THE EXPEDITION-DEIOPULATED STATE OF THE COUNTRY - ITS TRADE, RELIGION, AND LANGUAGE-ZHIBU - ATTEMPT TO VISIT WUKARI-SIIUFFLING CONDUCT OF TIE KING-GOODWILL OF THE CIIETS AND TEOPLE- 
PROGRESS TO ANYISHI-FAFOURABLE INTERVIEW WITH AGBO AND THE NEIGHBOURING CHIEFS-VISIT TO ANUFO -OPPIESSION OF THE FILANIS-HUMLLATING POSITION OF THE CONQUERED CHIEFS - INTERVIEW WTTH THE CHIEF OF ROGAN-KOTO-REPORT OF THE MESSENGER FROM KEANA CONCERNING THE TWO WHITE TRAVELLERS - EKEREKU - RAPACIOUS CONDECT OF THE FILANIS ABATSHO-MOHAMMA, CHIEF OF PANDA-AMARAN MARKET - REPUBLIC OF YIMMAHA-KINDLY RECEPTION THEREDESTRUCTION OF PANDA BY THE FILANIS-WILLINGNESS OF THE PANDA PEOPLE TO TRADE AND RECEIVE MISSIONARIES - RETURN TO THE CONFLURNCE . . .

CHAP. V.

SICKNESS OF TWO OF THE PARTY LEFT AT THE CONFLUENCEEXCELLENT HEALTH OF THE EUROPEANS IN THE 'PLEIAD' -DISSATISFACTION OF AMA-ABOKKO-DESIGN OF AMA AND DASABA TO BUILD A TOWN ON THE LAND PURCHASED BX THE BRITISH GOVERNMENT IN 1841-ZURI'S MISCONDUCT RBPORTED TO AMA-FRIENDLINESS OF THE NATIVES AND THEIR DESIRE FOR THE RE-ESTABLISHMENT OF THE MODEL FARM, AND TO BE TAUGHT GOD'S WORD-SYMBOLIC LETTER TO A NUPE IN SIERRA LEONE-WISH FOR THE RETURN OF THE SIERRA LEONE PEOPLE TO THEIR COUNTRYGROWING POWER OF ABOKKO'S PARTY-IDDA-HISTORY OF THE RISE OF THE ATTAS-FRIENDLY RECEPTION AT ASABA-SUITABLENESS OF THAT PLACE AND OF ONITSHA FOR MISSIONARY STATIONS-FANCX CLOTHS, \&c. AT ONITSHA MARKET-OSSAMARE-ABOH-INTERVIEW WITH AJE - HOSPITABLE TREATMENT RFCEIVED BY SIMON JONASDESCRIPTION OF THE TOWN-CALL UPON THE CHURCH TO PREACH THE GOSPEL THERE-AGBEKUN'S VISIT TO THE TSHUKU-INTERVIEW WITH THE CHIEF OF AGIAMARECROSSING THE BAR-ARRIVAL AT FERNANDO PO . . 161 


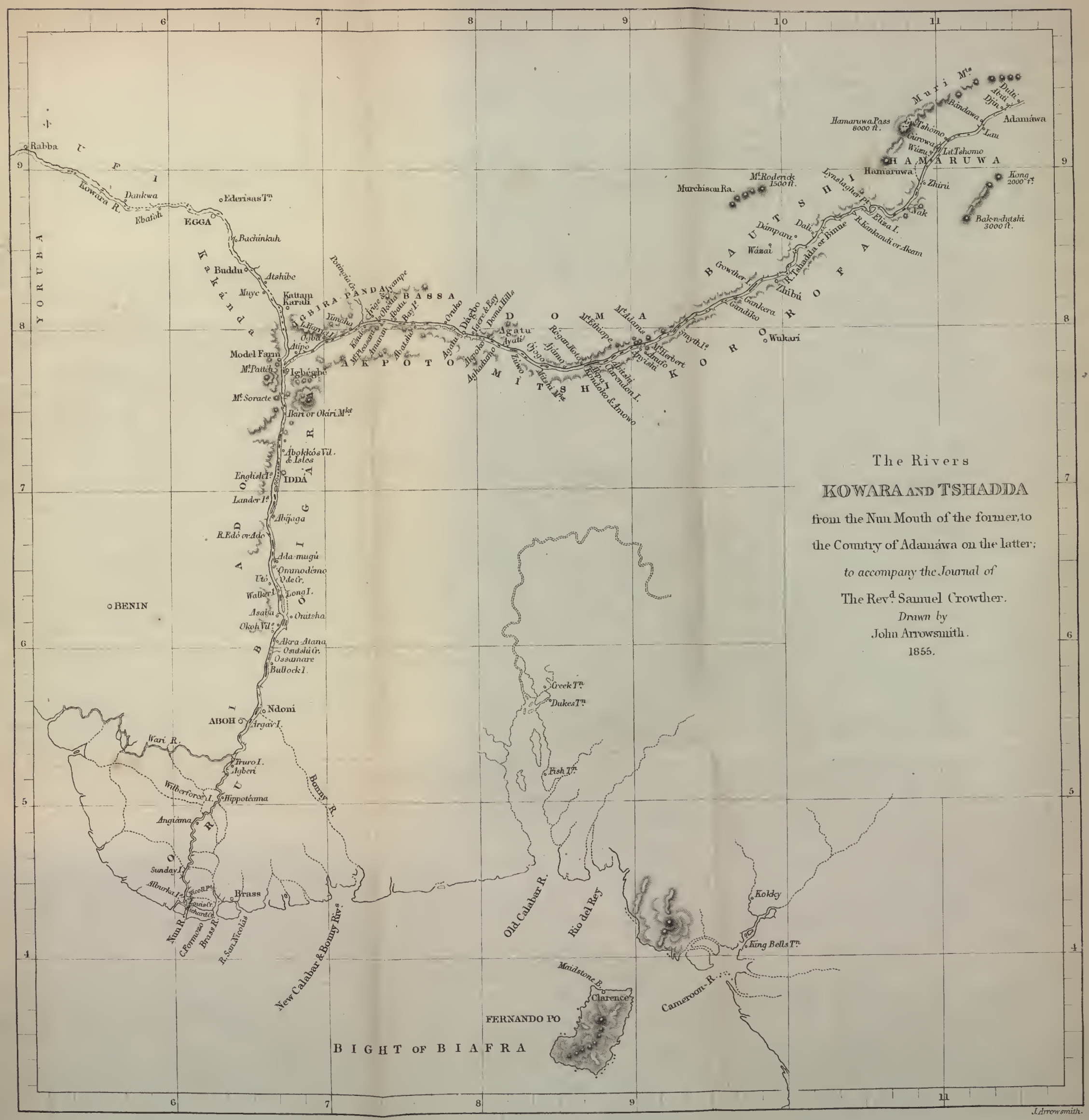





\section{PREF ACE.}

Is the summer of 1853, Macgregor Laird, Esq., a merchant of London, long and extensively engaged in the West African trade, entered into a contract with Her Majesty's Government to fit out and send a small steamer to the river Niger, to asccnd the stream to the confluence with the Tshadda, and then to explore that branch of the river. The object of the Expedition was to cstablish commercial rclations with the native tribes: it was also hoped that Dr. Barth, the celcbrated African travellcr, would be met with in that part of the country.* Hcr Majesty's Government was to appoint ccrtain officers to accompany the Expedition, and Mr. Laird was to provide for trade and barter witl the natives. The risk and main cxpense of the

* About the time when the earlier sheets of The Journal were passing through the press, rumours had reached this eountry that Dr. Barth had lost his life in Afriea; and henee tlee doubt respecting him expressed in a note, which will be found in p. 19. Dr. Barth, happily, has since returned to this country in safety. While the Expedition was up the Tshadda he was at a considerable distance in the interior. 
undertaking rested with Mr. Laird, who immediately made to the Committee of the Church Missionary Society, the generous offer of a free passage for the Rev. Samuel Crowther, if he might be allowed to accompany the Expedition. After communicating with Africa, and ascertaining Mr. Crowther's willingness to go, the Committee thankfully accepted $\mathrm{Mr}_{\mathrm{r}}$. Laird's offer. This act of liberality on the part of Mr. Laird, is only an additional proof of the lively interest which he has long taken in promoting the best interests of the natives of Africa.

Mr. Crowther had accompanied the former Niger Expedition in 1841, under Captain H. D. Trotter, R.N., of which an account was published by the Society, containing the jommals of the Rev. C. F. Schön and Mr. Crowther. Another member of the present Expedition, Mr. Simon Jonas, a native Cluristian, had also accompanied the former, as an Interpreter.

The general results of this Expedition, as contrasted with all former attempts, are ably stated in letters written after its return by Mr. Laird to the Earl of Clarendon, which are with his Lordship's permission, here inserted. 
Mr. Macgregor Laird to the Eari of Clarendon.

\section{3, Mincing-lane, 8th Feb, 1855.}

\section{MY LORD,}

I HAVE the honour and pleasure to inform you that the exploring steam-vessel 'Pleiad,' has safely returned from the Chadda, after ascending 250 miles beyond the point reached by former Expeditions.

The exploration occupied 118 days, and was unaccompanied by any loss of life; marking a new era in African discovery, and showing that by means of her navigable streams, the interior of that immense continent, may be safely and economically brought into relation with the civilized world.

I beg leave to congratulate your Lordship on the success which has attended an enterprise, promoted principally by yourself, and trust that that success will be followed up annually for some years to come, until the interior of that great continent is fully explored by the countrymen of Park and Clapperton, under their national flags.

These immense African rivers being now proved accessible to Europeans under proper management, and at the proper season with impunity, my object in offering to contract for the service is attained, and I must decline proceeding further, as the outlay of 
capital necessary is too great a strain upon my private means; and the loss already sustained is quite as much as $I$ am justified in sacrificing, even for such an object.

I have the honour to remain, My Lord, Your obedient servant, M. LAIRD.

The Right Hon. Lord Clarendon.

Mr. Macgregor Laird to the EarL of Cliarendon.

3, Mincing Lane, 5th NIarch, 1855.

\section{MY LoRD,}

THE result of the late ascent of the Chadda has been so successful in proving the practicability of exploring Central Africa by her magnificent rivers, which in all tropical countries, and in Africa especially, are the natural lines of communication, that I trust Ifer Majesty's Government will persevere in following up the geographical discoveries so ably commenced by Dr. Baikie; and though the expense and risk has proved too great for me, individually, to again offer my services on the same terms as contractor, the interest I take in the subject may excuse my now addressing your Lordship.

Standing out in broad relief from all former ascents of the Niger or land expeditions of discovery into Central Africa, the Chadda exploration is re- 
markable for the safe return to this country of all Europeans engaged in it.

In 1805, Mungo Park perished descending the Niger with three companions, the survivors of 38 men who left the Gambia with him.

In 1816 Captain Tuckey's Expedition to the Congo failed, and only one survivor of it reached England.

In 1821 to 1824, Denham and Clapperton's Expedition from the Mediterranean to Soudan, lost its leader, Dr. Oudney, and other Europeans.

In 1825, Clapperton himself, and his companions, Captain Pearce and Dr. Morrison, lost their lives penetrating the Continent from the Bight of Benin, his servant, Richard Lander, being the sole survivor.

In the same year, Major Laing perished after reaching Timbuctoo.

- In 1830, Richard and John Lander reached the Niger from Badagry, and floating down the stream, discovered its embouchure on the Bight of Biafra.

In 1832 and 1833, the Liverpool Expedition (the first ascent of the Niger from the sea) took place under my command. We lost 40 out of 49 Europeans.

In 1836, 1840, and 1845, the late Consul Beecroft made the ascents of the Niger with considerable loss of European life on each occasion.

In 1841, the Government Expedition under Captain Trotter, lost, in 62 days, 42 white men out of 150 .

The Chadda expedition may be therefore consi- 
dered to mark a new era in African liscovery; the deadly climate having been fairly met and conquered by improved medical treatment and mechanical organization. The plausible objection tn exploring Africa-the risk of life-is answered; and the question now is, whether, after the lives of so many gallant men have been sacrificed, during the last half century, in clearing the way, and that way being now proved to be safe and practicable, Her Majesty's Government will, at an expense of a few thousands annually, complete the work of discovery in Central Africa, or allow that honour, which ought to belong to the British race, to be reaped by others.

Whatever ultimately may be the commercial value of the trade of Central Africa, the results of all trading expeditions hitherto have proved its present amount to be not equal to the expense of getting at it. Speaking as a mercantile man, there is no inducement to follow up the trade. For years it must be a losing one; and if after seven or ten years it became profitable, others would reap its benefits equally with the first adventurers.

As to any appreciable effect the continuance of the exploration would have upon the foreign traffic in slaves, theat depends so much, if not altogether, upon the demand in the Western hemisphere, that annual expeditions for years to come could not possibly affect it.

The reasons I venture to urge upon your Lordship to continue the exploration of Central Africa are, the scientific and geographical results that it is 
proved may now be realized, at little risk of life, in the unknown countries which extend over 25 degrees of latitude, and 50 degrees of longitude, and which are virgin ground to the traveller. The great importance of keeping up the spirit of enterprize and research in our countrymen, and the advantage we possess in having in the educated African youth in the Colonies of the Gambia, Sierra Leone, and the Gold Coast, most efficient Native agents; by their means new energy and a higher standard of living may be introduced naturally, unobtrusively, and rapidly, into the remotest regions of the interior.

To succeed, this return of the civilized African to his native country, carrying the English habits and language with liim, must be spontaneous and self-supporting.

The next point is to make the communication annual and regular, so as to give the people confi-. dence in the periodical visit of a steamer.

I attach great importance to the annual visit of the steamer, as it would prevent the tribes in the Delta stopping the passage of the people above them to the sea-enabling them to open direct communication with the trading vessels at the mouths of the rivers.

From the observations of Dr. Baikie, it would appear the month of June is the best time to enter the Niger. This would require the steamer to leave this country in $\Lambda$ pril, so that if the expedition is to be renewed, an early decision must be come to. I am still of opinion that the best way to carry it on is by contract for a certain number of 
years. The expense is then fixed, and the contractor has every inducement to encourage the trade, and keep on good terms with the natives But if the Government wish to carry it on entirely with their own officers, after the experience acquired, and consider the 'Pleiad' a suitable vessel for the purpose, I will hand her over, at a valuation, on her arrival in the Thames, and give every assistance in my power to forward the enterprize; or if any private individual undertakes it, I will be glad to afford him all the information I possess as to the trade, and if he wishes it, deliver the 'Pleiad' to him on the same terms.

I take for granted that Her Majesty's Government have no intention of forming any settlement, or interfering with the native powers in Central Africa. I should very much regret if any such attempt was made. The only hope of improving the interior is by African influence, introducing a superior race of negro blood. This can be found to considerable extent in the youth of our own Colonies. They volunteer for the work, and all that is required is to open the way for them. When in the interior they will soon assert their superiority, and may be safely left to take charge of themselves.

I know, my Lord, that it will be said the time is not favourable for a renewal of African expeditions; that other and more vital affairs occupy and engross the attention and mind of the public; but I trust and know that this is not, and never was the true feeling of the great mass of my countrymen. Fifty years back, while engaged in a far 
severer struggle than the present one, they sent out Mungo Park to explore Central Africa for the pure love of science; and the present gencration will as readily support your Lordship in carrying out the work you have commenced.

I have the honour to remain, \&c., \&c.,

M. LAIRD.

The Right Hon. Lord Clarendon.

To these letters must be added one from the Rev. S. Crowther, in which he takes a brief review of the Expedition, and makes a forcible appeal on the importance of immediate measures to improve the existing facilities for introducing Civilization and Christianity amongst his countrymen, in the regions of the Niger.

The Rev. S. Crowther to the Rev. II. Venn.

REv. AND DEAR SIR,

'Bacchante,' at Sea, Dec. $2,1854$.

You will, no doubt, be glad to hear that we have returned from the Niger in good health and spirits, - a singular instance, without any death, either among the Europcans, twelve in number, or among the fifty-four $\Lambda$ fricans, cither from sickness or accident. The Expedition was in the river exactly 
sixteen weeks, the very day it returned to the mouth of the Nun. We commenced our ascent of the Tshadda on the 7th of August, and the last point we were able to reach was Gurowa, above Bomanda, a port of Hamaruwa, ${ }^{*}$ about 300 miles from the confluence of the Kowara and Tshadda, on the 22nd of September, when we were completely short of fuel, no wood being obtainable within three or four miles of the banks of the river. This was the only difficulty we met with, and which prevented our reaching the confluence of the Binue and Faro, where it was crossed by Dr. Barth, and, according to all the accounts we have received, could not have been more than 100 miles from Hamaruwa. It could be reached in five days' journey on foot, travelling by the course of the river, but dangerous on account of unsubdued natives, and ten days' journey by a circuitous route around the Fumbina mountains, which was said to be safer. The reception we met with all along from the kings and chiefs of the countries on the Binue was beyond expectation. We made two visits to Mohamma, the Sultan of Hamaruwa, fourteen miles from the river, in both which we were most respectfully received and entertained by the Sultan.

We returned to Aboh $\dagger$ on the 31st of October, and met Simon Jonas, whom we had left there, quite well and much respected by all, both chiefs and people. He moved about among them with perfect freedom, and made several visits up the river, to Os-

* Spelt Hamarrua in Mr. Koelle's map.

+ Ibo or Aboh, the chief town of the Ibo Tribe, situated on the upper border of the Delta of the Niger. 
samare, Onitsha, and Asaba markets, and to an interior town called Oko-Ala, on the back of Aboh, of about a day's journey; the chief of which place asked Simon Jonas, why we always stopped at Aboh, and never paid them a visit; to whom Jonas replied, that there will not be left a place unvisited in due time. He was about three days absent from Aboh, when he returned, for fear the steamer might arrive in his absence.

Simon Jonas spoke to them of the folly of their superstitious customs, and he said, the one of chewing stick to clean their teeth early in the morning, and spouting the spittle before their country fashion, invoking his blessing upon those who wish them good, and imprecating his anger upon those who desire their hurt, was given up by some of them at his speaking to them of the folly of so doing. He was the companion of Tshukuma and Aje, although he paid them due respect.

Having found this favourable state of things in Abol, I took the step to secure a parcel of ground for a contemplated Mission station, to prevent the spot being spoiled by the pcople, and gave $A$ je strict charge to keep the people away from it. My further proceedings in Aboh will be seen more fully in my journal to that place. I have furnished the Bishop of Sicrra Leone with a copy of my journals to Aboh for his fuller information; and I have suggested to Dr. Baikie the advantage of taking Simon Jonas to Sicrra Leone, to give his Lordslip verbal information of Aboh country from actual knowledge of three months stay among them. I have taken these steps 
from the instruction I had received from the Bishop, to ascertain what reception Native Teachers would meet with in Aboh should any be sent there.

I regret much that none of those who accompanied Mr. Jones* to the same place for the same object had been sent with the Expedition.

I believe the time is fully come when Christianity must be introduced on the banks of the Niger: the people are willing to receive any who may be sent among them. The English are still looked upon as their friends, with whom they themselves desire to have connexion as with the first nation in the world. Could the work have been begun since 1841, how imperfect soever it might have been, yet it would have kept up the thread of connexion with England and the countries on the banks of the Niger. God has provided instruments to begin the work, in the liberated Africans in the Colony of Sierra Leone, who are the natives of the banks of this river.

If this time is allowed to pass away, the generation of the liberated teachers who are immediately connected with the present generation of the natives of the interior will pass away with it also; many intelligent men who took deep interest in the introduction of trade and Cliristianity by the Niger, who had been known to the people, have died since; so have many of the chiefs and people in the country, who were no less interested to be brought in connexion with England by seeing their liberated coun-

* The Rev. E. Jones, with three natives of the Ibo Tribe in Sierra Lcone, attempted to reach the Ibo country in April, 1853, but found it unsafe to ascend the Niger without a steamer. Vide "Church Missionary Intelligencer," Novcmber 1853. 
trymen return. Had not Simon Jonas been with us, who was well known to Obi and his sons, we should have had some diffieulty in gaining the confidence of the people at Aboh at our aseent.

It would be of very great advantage if the colonyborn young men were introduced by their parents or eountrymen to their fatherland; it lias many advantages which have not been sufficiently notieed. It eanuot be expeeted that ehildren born in the Colony should beeome acquainted with the countries and characters of the people so soon as their parents and eountrymen. Though the parents are illiterate, yet if they are sineere followers of the Lord Jesus Christ, their service will be of mueh worth in introducing Christianity to their own people. They are brought back to their eountry as a renewed people, looked upon by their eountrymen as superior to themselves, as long as they eontiuue consistent in their Christian walk and conversation, and do not disgraee themselves by following lieatlienish praetiees. The language of the people of Abbeokuta will be that of the natives on the banks of the Niger: "Let those who come from the white man's country teacl us and condemn our heathenish praetices, we shall listen to them." It takes great effeet when returning liberated Christians sit down with their heathen countrymen, and speak with contempt of their own formor superstitious practices, of whom, perhaps, many now alive would bear testimony as to their former devotedness in their superstitious worship; all which he now can tell them he lias found to be foolishness, and the result of ignorance; when ho with all earnestness, 
invites them, as Moses did Hobab, Come with us, for the Lord has promised good to Israel : and all this in his own language, with refined Christian feelings and sympathy, not to be expressed in words, but evidenced by an exemplary Christian life. The services of such persons will prove most useful in the introduction of the Gospel of Jesus Christ among the heathens. Let such persons be employed as readers or Christian visitors, and thus they will gradually introduce their children into the country, who in course of time will be able to carry on the work more effectually; as pioneers, we must not look for instruments of the keenest edge, anything that will open the path for future improvement will answer as well at the onset.

I shall entrust my journals to the care of Dr. Baikie, made up into a parcel with some specimens of translation of Doma or Arago language, and that of the Mitshis, not found among Koelle's collection. I have also sent under his care a long red box, containing curiosities from the river, which I hope will safely reach you.

I remain,

Rev. and dear Sir, \&c.

Samuel Crowtimer. 
Dr. Baikie to the Rev. S. Crowther.

Clarenee, Fernando Po, Norember 28, 1854.

My dear Mr. Crowther,

After having been together for upwards of four months, closely engaged in exploring Central Africa, I cannot allow you to depart without expressing to you, in the warmest manner, the pleasure I derived from your company, and acknowledging the information I have reaped from your,

Your long and intimate acquaintance with native tribes, with your general knorvledge of thcir customs, peculiarly fit you for a journey such as we have now returned from, and I cannot but feel that your advice was always readily granted to me, nor had I ever the smallest reason to repent having followed it. It is nothing more than a simple fact, that no slight portion of the success we met with in our intercourse with the tribes is clne to you.

Our voyage lias providentially terminated so far favonrably, and without loss of life.

You are now abont to return to the scenc of your past labours, and to resume your share of the work for civilizing and regenerating a vast tcrritory. That your labours may continue to meet with success, and that yon may be spared to see your exertions bearing good fruit, is the earnest and sincere wish of

Yours very faithfully,

IV. B. BAIKIE. 
The prospects opened by this Expedition acquire an additional interest when viewed in connexion with the extension of the Yoruba Mission, which has already reached several large towns, connected by intercourse with the tribes on the banks of the Niger, at various points, extending many hundred miles from its Delta. In a journal, just received from Mr. Crowther, after his return to this Mission, he thus notices his visit to Ibadan, which is the most Easterly of the towns at present occupied by the Missionaries of this Society.

\section{Extract from the Journal of the Rev. Samuel Crowther.}

Jan, 1855.

"I told Bôlle, the chief of Ibadan, that I had lately returned from the Niger, and that I had heard of his soldiers being with Dasaba, in that neighbourhood. He replied-Yes, that there were about 1,000 Ibadan soldiers with him. I said, liad we made arrangements to that effect previous to our ascent up the Tshadda, I would have returned by way of Rabba or Lade, with his warriors, through Yoruba to Ibadan. He said, certainly, that I could have done so, and that it miglit be done now from here to Rabba and Lade, on the banks of the Niger. With prudent management and means to effect it, how easily the road could be opened across the Yoruba country to the Niger! The opportunity should be 
embraced when we can get the aid of the chiefs in accomplishing such an object: it is much better to act in co-operation with them, than withont themthey know their own interest in having Europeans for their friends, and with a little encouragement they can be made use of in effecting much in this country.

The disposition of the people at Ibadan though warlike, yet is not unfavourable to peace and trade; they are not worse than the Egbas of Abbeokuta, and I have seen even at Ibadan the effect of the establishment of lawful trade at Lagos. Palm oil, with whicl Ibadan abounds, is a chief article of trade at this time, large calabashes full are conveyed through the Ijebu country to the coast, and others find their way to Abbeokuta, where it is sold to the Egbas, who convey it to Lagos, in their numerous canoes, by the Ogun river.

Cotton is another staple article of trade, which will largely occupy the attention of the people in general in this country: the extent of farms now under cultivation in cotton and other produce, thongh merely for home consumption, was not known in Ibadan for many years back. How much will it be extended if they are a little encouraged, and a market is opened for their cotton.

In order to take full advantage of the present opportunity, it is evident, as Mr. Laird has pointed out, that Her Majesty's Govermment should assist in keeping open this great river-road into the interior of Africa, at lcast for a few years: 
until the natives themselves shall become sufficiently sensible of the advantages of lawful commerce and the benefits of Christian Teachers, so as to co-operate, as among the Yoruba tribes, in maintaining a friendly intercourse with their European benefactors. A meeting of a few of the influential friends of Africa has been already held in London, in July last, to confer with Dr. Baikie upon this subject--Sir T. D. Ackland, Bart., M.P., in the chair, at which the following Resolutions were adopted:-

That it appears to this Meeting that the opportunities of introducing civilization and Christianity into Africa, by the navigation of the rivers Niger and Tshadda, contemplated in the Expedition of 1841, are shown to be still most promising by the late Expedition of $185 \mathrm{t}$, and that they should be promptly. improved by this country before they are closed by any cliange of circumstances, or taken out of our hands by other nations.

That it is essential to the success of any plans for the attainment of this object by means of Native agency, that Her Majesty's Goverument should establish or promote the establishment of a regular steam communication between Fernando Po and the confluence of the Niger and Tshadda rivers, in order that Native Traders may be assured that the way will be kept open; and also that Her Majesty's Government should, at periodical intervals, extend such communication further up the two rivers, with a view to the 
extension of geographical discovery, of commercial enterprize, and of religious civilization in the interior of Africa.

That should Her Majesty's Government accede to this proposal, there is every prospect of the completion of the great and benevolent object in view, by the spontaneous commercial enterprise of liberated and other Africans in the various settlements upon the West Coast, and by the zeal of Missionary Societies.

The Board of Admiralty have kindly sanctioned the insertion of a Map of the course of the rivers, reduced by Mr. Arrowsmith from a larger Admiralty Chart, furnished by the Naval Officers attached to the Expedition.

May the good hand of the Lord, which is evidently beckoning us forward in our efforts to reach these long isolated members of the human family, and to bring them within the circle of Christian civilization, direct and prosper all the measures which may be adopted for this end, and may He shortly establish His kingdom in this long-benighted region.

Church Missionary IIouse,

Oetober, 1855. 



\section{J O U R N A L,}

\&c. \&c. 
June 17: The 'Bacchante' arrived this morning from Fernando Po, and brought the painful intelligence of Mr. Beecroft's death, which took place the night before she sailed. I felt this very much as the Expedition was just expected, and I knew no other person connected with it besides him; this caused a little anxiety, but I resigned everything to God's good and unerring providence.

June 18: Sunday. Attended morning service in Mr. Gollmer's church, and in the afternoon at Mr. White's house, where I heard Mr. Phillip address the congregation.

June 19: To-day was spent in making necessary preparations, and writing letters for England, against the arrival of the mail.

June 20: 'The 'Forerunner' arrived about one o'clock P.M., by which I learnt that some of the gentlemen of the Expedition were on board of her, and that the 'Pleiad' would not touch at Lagos, but proceed direct to Fernando Po, so I prepared myself for embarking to-morrow morning.

June 21: About nine A.M., I embarked, and was very glad to meet Dr. Baikie, Dr. Bleek, and Mr. Dalton, a young zoological assistant, on board; they kindly brought me letters from England and Sierra Leone, and parcels of books and many useful articles from Lady Buxton and Captain Trotter, for which I was very thankful. I was sorry to find Dr. Bleek rather out of health, but it was thought he might be hetter by the time we arrived at Fernando Po. There was also on board, the Rev. J. Diboll, with Mrs. Diboll and daughter, Baptist 
missionary to Fernando Po: they were all very glad to see me. About half-past eleven A.M. the "Forerunner' weighed anchor, and in a short time we lost sight of Lagos.

June 22; Arrived off the Bonny river, where a ship was lying at anchor; the mail was left in charge of one of the passengers, who left the 'Forerunner', and went on board of her: she was waiting for the pilot to take her across the bar next morning; we made for Old Calabar. After crossing the bar we anchored for the night.

June 23: Arrived at Old Calabar about eleven A.Ir; as the mail was only to stop here a few lours I could not go on shore to advantage. Mr. IV. C. Thompson, son of the late Mr. W. C. Thompson, linguist, in connection with the Church Missionary Society at Sierra Leone, took his passage in her for England, and the missionaries accompanied him on board; about four o'clock P.x. we started, and anchored outside the bar.

June 24: Arrived at Cameroon river about seven P.M. The mails were delivered, and received that night.

June 25: Sunday. Started as soon as it was light, and made for Fernando Po. It rained heavily; in consequence of which no service could be held. About four P.M. we anchored off Clarence, and found to our great disappointment that the 'Pleiad' had not yet arrived: various thoughts were expressed and conjectures made, as may be expected, as to the cause of her non-arrival. I landed, and took my lodging at Mr. J. Wilson's, the same house I occupied in 
1841 with Mr. Schön, in which we held divine service during our stay in the island. The people were very glad to see me, and expressed their regret for the loss of Mr. Beecroft; for he had made full preparation for the Expedition; and had engaged many intelligent natives who had been used to go up the Niger with him, and who were ready to go anywhere with him, they being mutually attached to each other, for he treated them as a father. It will be a long time before his place can be supplied by another, who will take the same interest in the country and her people as he did.

June 26: Took my boxes on shore to my lodging; every one was on the look out for the 'Pleiad'. After breakfast, visited Mr. Beecroft's grave, which is on the point of the cliff of Clarence, under a large cotton-tree, where he himself had directed that he should be buried. Thus ended the life of this useful person, after twenty-five years stay in Africa, during which period lie had won the affection of many who knew his worth in the countries he had visited; and could not but greatly regret to hear of his removal by death. The chiefs of Abbeokuta had sent salutations and messages to him by me, which he did not live to receive. As long as this generation lasts, the name of Mr. Beecroft will not be forgotten in this part of West Africa.

June 27: The 'Pleiad' had not arrived, and the 'Forerunner' would not have waited any longer, had not Captain Miller, senior officer of Her Majesty's squadron in the Bights, ordered her to stay till Tliursday. 


\section{ARRIVAL AND DEPARTURE OF THE 'PLEIAD.' 7}

June 28: The 'Pleiad' arrived this evening, to the great joy of all parties.

June 29: 'The 'Forerunner' had been detained two days beyond her time, or she would have towed the 'Pleiad' off the Nun, in order to save fuel; she sailed away this evening with our letters for England. Dr. Bleek's state of health being considered by the medical gentlemen to be very precarious, he was pronounced unfit to accompany the Expedition, and was consequently sent back to England by the 'Forerunner.'

July 2: Sunday. Held the morning service in Mr. Beccroft's new house, which Mr. Lynslager had kindly ordered to be cleared out yesterday for the purpose : the service was well attended, both by resident Europeans and many from the ships in the cove, besides many of the Native settlers in connection with the Baptist Church; Captain Miller, of the 'Crane' was also present. I preached from 2 Cor. v. 1.

July 3-7 : Captain Miller rendered every possible assistance to hasten the departure of the 'Plciad', and as his help was no more needed, he sailed away to-day.

July 8: This afternoon, I embarked on board the 'Pleiad', as she was to sail this evening. About nine P.x. we weighed for the Nun, with two large iron canoes laden with coals in tow; the friends who accompanied us a short distance from the harbour left us with hearty elieers. As the wind rose, and the swell became heavy, the canoes did not tow well, and there was some fear of their being 
upset: the night was, therefore, past with some anxiety.

July 9: Sunday. Heavy rains: we were not much more than twenty miles from Femando Po. The canoes continued to labour from the heavy swell and a strong current; the steamer could not go more than half her speed for fear of swamping the canoes. About noon, the spindle of the safetyvalve gave way, and steam could not be kept up, so we could not proceed until it was repaired, which took three hours, and we were drifted eastward by the westerly current, with heavy swell and rains. Nearly all hands were sea-sick, no service could be held.

July 10: Off the mouth of the Bonny river; our progress very slow; the safety-valve out of order, in consequence of which we were many times short of steam.

July 11: Off the mouth of the St. John or Brass river; anchored for the night between it and the mouth of the Nun.

July 12 : About two P.M. with the flood tide we crossed the bar; * the 'Pleiad' was piloted by Mr. Thomas Richards, a Yoruba man, who had made many voyages up the Niger with the late Mr. Beecroft, and has a good knowlerlge of the localities about the coast and the Niger. When we were in the midst of the bar, the hawser of one of the canoes, in which there were seven Krumen, broke, and as

* In the former Expedition this same bar was crossed one month later in the year, viz. August 13th : and a week was spent before the vessels began to ascend the river. ED. 
we could not stop to render her any assistance, she was left to make the best of her way through the surf, though not without great anxiety for the men; for the surf was tremendous, so much so that it broke once over our poop, though the tide was in our favour: every eye was fixed upon the drifted canoe, and it was no small joy to see her now and then buoyed up from the deep furrow upon the top of the surf, following our track, till she got across in safety :- the iron canoes seem to ride very lightly upon the surf. About three o'clock we anchored inside the bar very near to Alburka Island : when the engineer came to cxamine the engine, he found that the safety-valve was just gone, and it was providential that we had got across the bar before this liappened.

July 13, 14: These days were spent in repairing the engine; and on the 15th, about six A.M., we got under weigh for the Niger. Louis' Creek was found blocked up, so Mr. lichards took a boat to sound the next creek, the 'Pleiad' waiting at the entrance. He returned about half-past nine A.M., and reported that he had found the channel. We started, with the tide still in our favour; but about twelve o'clock we missed the right clianmel, and ran aground on the point of Sunday Island, the left passage having been taken instead of the right, which was the proper channel; we could not get the vessel off this evening.

July 16: Sunday. With the flood tide exertions were nude, and the vessel was hove off about halfpast eleven A.M. ; but before the ship could be put to 
rights, it was too late to make any progress. I had service in the afternoon about two o'clock, and preached from St. John i. 22, 23. All hands well and cheerful. When we were lying aground this morming, a canoe was seen paddled down the river with produce; another came alongside with four men in, unarmed, to see the ship, they asked whether she was a slave or oil ship:-they were answered 'palm-oil ship.'

July 17 : We got under weigh abont seven A.Mr. and made good progress in three to seven fathoms water. Soon after we had cleared Sunday Island, traces of cultivation began to appear, together with land about three feet above the water's edge. As the water has not yet risen to its full height, it gave an entirely new appearance to the river, from that it bore in August 18t1. At that time, only a few spots near the water's edge were under cultivation, and the whole was covered with water, as the river overflowed its banks. Not only old plantatious showed a continued industry of the people of the Delta, but many newly-cleared spots, in the midst of which numerous lofty palm trees stood, which were carefully preserved for their lich and valuable jroduce, showed further, the improved state of the banks. About three hours from Sunday Island, we came to inhabited villages; we induced two canoes to come off, from whom we learnt that the people between Brass and Aboh are called Oru. One of the people who came off, and who spoko the Ibo langrage, was so confident, that he offered to go with us to Aboh; and the people on shore, nercr 
showed the least sign of opposition, but folded their arms and gazed at the steamer as she glided on. Fewer traces of cultivation were observed during the day till we came to the village of Angiama. Brass people come up here to buy palm-oil with large casks in their canoes, some of which they land as they proceed upwards. There is another striking change in the habits of the people themselves; in 1841 , very few of them were to be found with any decent articles of clothing; I spied to-day, among a group of about forty people on shore, fifteen who I could distinctly see had English shirts on. This is an evident mark of the advantage of legal trade over that in men. The chief of Angiama, or Anya, came off, and expressed his regret, that we did not wait at his village, as Captain Trotter had done; and it was with some difficulty that we could satisfy him by our excuses; but we hoped to be able to stay on our return. Dr. Baikie gave him a red cap and a looking-glass; but I could read in his countenance, as well as by the temper one of his men manifested, that, if they had had it in their power, they would have detained us in Oru, to reap all the benefits of the trade to themselves, instead of allowing it to pass through their waters to the people of the interior beyond them. To-day's voyage occupied eleven and a half hours.

Since we entered the Nun, I have been thinking what could have made this river more unhealthy than any other, independent of the general unhealthiness of the climate. It occurred to me, that the evil might have partly originated in the Ex- 
perition itself, as nothing had been left undone, especially in 1841 , to ensure good health : that, probably, miasma may have been created by the raw and green wood for fuel kept in the bunkers for days together, and by the noxious exudation and vapour issuing therefrom, and by the mixture of chips and bark with the bilge water. $I$ hinted this idea to Captain Taylor, Dr. Baikie, and Dr. Hutchinson, that a trial might be made of keeping the wood in the canoes, and only calling for it as occasion required: they all at once agreed to take every precaution which might be likely to conduce to health.

July 18: Got under weigh at seven A.Mr., and steamed past many villages on both banks; several canoes came off. The banks were about six feet above the water's edge, at intervals, on both sides; one is not impressed with the idea of a swamp by the sight of these high banks. The wind was fresh and pleasant. About noon, we were opposite a group of villages on the left bank, where a creek with plenty of water entered the main river; we followed it up about half-an-hour, but as it grew narrow and covered with green stuff and weeds, we returned; the natives also told us that it was not the way to king Obi. As we were returning, we met two canoes which were following us, waving a white piece of cloth as a sign of peace. It appears this signal is well known all along the river, and a great way into the interior. They told us that the creek led into the bush, and into a very narrow passage, which they called a hole. They received some trifling presents. About three o'clock we were opposite the villages 
of Kalabal and Okoloba, where in 1841 the "Wilberforce' re-entered the main river, and a note was left for the 'Albert's' information. * Here we met a number of Brass people, traders in palm-oil; they came alongside to sell live stock and provisions.

July 19: Got under weigh about six A.M. Our progress was rather slow, owing to a strong current. About noon we touched the ground on a point below Truro Island, and were about an hour in getting the vessel off; at a short distance, the channel being missed above Truro Island, we ran aground again in the afternoon, where we stayed for the night. Several canoes came off : we asked them respecting Obi, whose death was confirmed, and it was stated that Aje, one of his sons, was now in his father's room, but not recognised as his successor, until white men should come up and decide who should be king. This unexpected intelligence appears favourable as regards the confidence they have in white men. It gave us time to think what it would be best to do, should the matter be brought before the commissioned officer for advice.

July 20: We remained aground until five P.M., and thus lost a day's voyage. Some of the neighbouring chiefs of Oru came off, with whom we had conversation about legal trade, and in order to get it well established, we pointed out to them the necessity of agreeing among themselves, never to molest English boats or canoes passing up and down the river, as that would prove detrinental to

* See Schün and Crowther's Journal, p. 279. 
trade, and turn to their own disadvantage. Mr. Richards, who went to take the soundings this morning, returned in the afternoon, and confirmed the statement of the peuple; he had been told higher up, that they were waiting the arrival of the white men who should decide who was to succeed king Obi.

July 21: We left at six A.M., and anchored off Aboh* at five P.M. The river has fallen considerably since June, as there has been no rain ; we had some showers and a few wet days, but not sufficient to effect a change in the rise of the river; but, however, there was always sufficient water if the channel were carefully traced out. The 'Pleiad' drew more than seven feet water. A great number stood at each village as we steamed past them, to gaze at the motion of the ship; they missed the paddles, the 'Pleiad' being a screw ship, (which seemed to answer remarkably well,) so that the astonished villagers could not account for the power which propelled her onward against the strong current.

The people of Aboh showed still some timidity, on account of the affair of the late Mr. Carr, concerning whom the 'Wilberforce' came to make some enquiries. $\dagger$ When Mr. Beecroft last visited this place,

* In the journals of the former expedition, this name is written "Ibo." Ibo, or Igbo, is the name of a large country; Aboh is a district and town situated in Ibo.

$+\mathrm{Mr}$. Carr accompanied the expedition in 1841, to superintend the model farm at the Confluence, and was zealously labouring there for a short time, when he was taken ill with fever. The medical men deemed it necessary to take him on board the 
I believe in 1815, he went on shore to invite people on board before any would come off; and as they had been informed by mistake that he died three years ago, they did not know who the captain was, hence their shyness to come to the ship. After some hesitation, a canoe with five men came off to us with two yams, which were bought for one empty bottle: other canoes kept close to the beach at a great distance. The men who sold the two yams appeared to be strangers from $\mathrm{Oru}$, and could not speak Ibo well. On their return, they brought an

"Albert," on her return to Fernando Po. There he was soon restored to health, and being anxious to return to his post, he proposed to leave Fernando Po for the river Bonny, and proceed to the Confluence, by hiring a native canoe and crew. And whon her Majesty's ship "Pluto "left for that river, he availed himself of the opportunity, and took a passage in her, together with his native servant. At Bonny he suceeoded in obtaining a boat manned by some men who were strangers at the place, and who promised to take him as far as Aboh. They left, but from that time nothing more was heard of Mr. Carr, nor of his servant, and there ean be no doubt, but they were murdered for the sake of plunder. Some artieles of elothing, seen either at Aboh or near it, supposed to have belonged to Mr. Carr, gave rise to the suspicion, that Obi had been implicated in the matter. The good feeling previously existing between him and the British offieers was interrupted, and some aets of hostility committed on both sides. From Mr. Crowther's remarks we may gather, that those unpleasant feelings had not quite subsided, and that but for the good services and explanations of Simon Jonas, the expedition might have met with some obstaeles at $\Lambda$ boh. The officers of the present expedition are convineed that Obi had no concern in Mr. Carr's death. I have always believed, that if Mr. Carr had reached $\Lambda$ boh, he would have been safe in Obi's hands; and that, if he met with a violent death, it took plaee, in all probability, soon after his departure from Bonny. The late Mr. Beecroft entertained the same opinion.-J.F. Scliön. 
Aboh man alongside, who was evidently sent to see who we were. He would not come on board. Simon Jonas was therefore sent in their canoe to inform the chief that we were come. Before he reached the creek, a Haussa man, who was an old servant of Mr. Lander, named after himself (Aliheli Lander), was sent to inquire who we were, and to say that the chief was disappointed that the captain did not fire to announce his arrival. Aliheli accompanied Mr. Lander to Fernando Po and back, speaks English, and was subsequently employed by Mr. Beecroft in his voyages up the river, and is well known to many people where the vessels touched. He was slave to king Obi, but got his liberty at his master's death, as it appears, for his good services to him.

From Aliheli, we learnt correctly that since Obi's death there has been some dispute as to his successor. There is anotler party besides the line of Obi, Osai's family, which lays claim to the throne; that is the line of Oshiodapara. Obi's eldest son, who has a right to the throne, is Tshukŭma, otherwise called Okorobi, but he appears to lack energy, so that $\Lambda j e$ his younger brother, an active man, took the lead, as it appears, with the approbation of Tshukŭma: but the line of Oshiodapara contended for the throne in favour of one Orise, ${ }^{*}$ and demanded that if Obi's family would not give place to that of Oshiodapara, whatever they had paid to Obi as their king should be returned: so it appears the matter rests at present. Aje heads one party of the town, called

* The final $e$ pronounced as a broad open rowel. 
the king's party, and Orisè the other party, called Oshiodapara's party. It appears both parties are at peace. Unfortunately Aje and Orisè were not at home on our arrival, but absent at Igara, to which place they had gone some ten days before, to settle some dispute which lad taken place between the Atta's subjects, on which occasion, a woman of Oshiodapara's family was accidently killed. We sent Simon Jonas* to tell Tshukŭma that we intended to pay lim a visit the next morning.

July 22: Took an early breakfast, and about eight A.M. we started for the town of Aboh, which lies about one mile in length along the western bank of the creek, very thickly populated. We landed close to Tshukŭma's house, which was very small and confined; his old house having been lately burnt. $\mathrm{He}$ had been worshipping his god that morning, which we saw in his piazza, in a calabash placed in the front of a wall, covered with a white sheet. We waited about ten minutes before Tshukŭma made his appearance, dressed in a pair of thin Turkish trousers, a white shirt, a white waistcoat, and a string of coral beads about his neck: he is smaller in size and stature than Obi, lis father, is very soft in lis manners, and seems not possessed of nuch energy. He shook us all heartily by the hand, and in a short time the little square was crowded to excess, so that there was no room to move; and the place became so thronged, that it was difficult to keep onc's seat on the mat spread for our accommodation. Tshukŭma

* Simon Jonas is a native of the country, and was employed in the Expedition of 1841 . 
used all his efforts to command silence, but to no purpose. Obi's daughter and the chiefs' wives took their turn to command silence, but it only increased the noise. At last, Tshukŭma requested us to frighten the people away, which of course we did not do. As it was impossible to obtain perfect silence, I suggested to Dr. Baikie to begin business, as we could manage to keep close enough to hear each other.

The substance of Dr. Baikie's interview with the chief was, that the Queen had desired him to visit them, and see how they did; that we were sorry to hear of Obi's death; we hoped his successor would be of the same mind as the late king, and that they still adhered to the treaty he had signed with Captain Trotter, who acted in the name of the Queen; and that trade was now come to the Aboh country, about which Dr. Hutchinson would speak fully with him. Tshukŭma replied, that he was very glad to see a large ship come to Aboh again, and that he and the other headmen were particularly charged by Obi, before his death, not to deviate from the path he had trod, respecting lis friendship with the white men, and that they would act accordingly; but as Aje was absent from home, in Igara, with a great number of the headmen, to settle some matter in that place, he expressed a wish that we would wait till they returned, as he expected them in three or four days' time, and he would send a canoe to hasten their return. To this we objected, because we were in a hurry to go up to fetch down some white men, who were waiting for us in the 
interior.* Tshukŭma said, the fault was not with them, but with the white men themselves; that many times promises of trade had been made to them, but never fulfilled. I told him that the English had it much in their mind to fulfil their word, but could not do so till now on account of sickness. Tshukŭma replied, Had they not gone further than Aboh, they would not have been taken ill, and been obliged to return to the sea so soon as they were.

I now thought it time to introduce the subject of a Missionary establishment among them. I told him that we had come to see what we could do to make a Missionary station at $\mathrm{Aboh}$, as we had done in my country at Badagry, Lagos, and Abbeokuta, and has been done also at Calabar and the Camaroons. One of Obi's daughters replied, that they could not conceive why white men should build houses in Bonny and Calabar, and not in Aboh? I told them that our superiors have been thinking of it a long time, but now they are in earnest, and are very desirous of sending some Ibo teachers to Aboh, to reside there, and teach them many things, if they are willing to learn. Tshukŭma said, my words were too good for them to hope that they will be realised, and that he would not believe any thing until he had seen us do what we proposed; that there was no difficulty on their part, nor need we fear any

* When the Expedition left England, it was hoped that Dr. Barth and Dr. Vogel, who have penetrated $\Lambda$ friea from the north, might bave been able to meet the 'Pleiad.' But subsequent aceounts have shown that neither of them could have been in that neighbourhood at the time, even if Dr. Barth still survives. 
unwillingness to receive those who may be sent to them or learn what they may be taught; but that the fault rests with us in not fulfilling what we promised to do.

To show that I was in earnest in what $I$ had said, I told him that I would leave Simon Jonas with him till our return, and that when Aje and the other chiefs came back, we would talk the matter over more fully. He was very glad to hear of my intention to leave Simon Jonas with them. After this, we asked his permission to walk about the town. He himself accompanied us to Aje's house, which was more capacious, drier, and better built than his own, in squares. We sat down there a while, on mats spread on the floor for us, and soon after left for the town. The river was greatly fallen, in consequence of which, the only street which runs parallel with the creek was free from water, but moist, and it gave us the advantage of walking to a considerable distance, crossing many gutters formed by the washing of the earth of the cross streets into the creek. In this long street, canoes are paddled to the very doors of the houses at high water. It is very much to be regretted that such a thickly-populated place as this is not better situated; however, this should not be an objection to answer the call, "Come over and help us;" their" willingness to receive teachers, and to be instructed, amounts to such a call. The chief said, I should see at my return the driest spot which would answer our purpose. Tshukǔma being invited on board, he returned home to make realy, and we returned to the ship about half-past ten A.M. A short time after, 
the elief came on board, aeeompanied by his head wife, Aje's head wife, and three of Obi's daughters. Captain Taylor had some talk with him about trade, and took him, and his male and female followers to the saloon, where they were invited to luneh, whieh they seemed to enjoy very mueh; after this, Dr. Baikie gave presents to himself and to his female attendants. He engaged to eut wood for us, which he promised we should receive in the afternoon, but he was unable to fulfil his promise, on aecount of the short notice, and his people not being near at hand. Tshukŭma never mentioned that there was any dispute among them relative to their polities; so we, of course, appeared ignorant of the matter, but the frequent mention of the king's party eonfirmed the report of the existence of differences among them.

July 23 : Sunday. Had serviee on board at halfpast ten, and preaehed from St. John i. 29. The boat was just ready for me after serviee, to go on shore to see and speak a few words with the chief on religious subjects, and also to ask his permission to address the people in the town, when his eanoe appeared from the creek, with numerous attendants, so I postponed my going till his return; but he remained so long on board, that there was no prospeet of his soon going away. When Captain Taylor had done with him, I took the opportunity to speak with him at length on the subjeet of the Christian religion, Simon Jonas interpreting for me. The quickness with which lie cauglit my explanation of the allsuffieient sacrifice of Jesus Christ, the Son of God, for the $\sin$ of the world, was gratifying. I en- 
deavoured to illustrate it to him in this simple way. "What would you think of any persons, who, in broad daylight like this, should light their lamps to assist the brilliant rays of the sun to enable them to see better?" He said, "It would be useless; they would be fools to do so." I replied, "Just so ;" that the sacrifice of Jesus Christ, the Son of God, was sufficient to take away our sins, just as one sun is sufficient to give light to the whole world: that the worship of country fashions, and numerous sacrifices, which shone like lamps, only on account of the darkness of their ignorance and superstition, though repeated again and again, yet cannot take away our sins: but that the sacrifice of Jesus Christ, once offered, alone can take away the sin of the world. He frequently repeated the names, "Oparra Tshuku! Oparra Tshuku!" Son of God! Son of God! As I did not wish to tire him out, I left my discourse fresh in his mind. The attention of his attendants, with the exception of a few, was too much engaged in begging and receiving presents, to listen to all I was talking about. I gave 'I'shukŭma a Yoruba primer, in which I wrote his name; and left some with Simon Jonas, to teach the children, or any who should feel disposed to learn, the Alphabet and words of two letters. Tshukumma and his attendants were perfectly at home in the steamer, and it was not till a gentle hint was given them, that the gentlemen wanted to take their dinner, that he ordered his people to make ready for their departure, at half-past four o'clock. He desired Simon Jonas to accompany him in his canoe, but I told him that I would 
send him afterwards. He gave Captain Taylor one bullock, seventy yams, and two hundred pieces of fire-rood. Simon Jonas was sent on shore in the evening with a supply of four thousand cowries and seven fathoms of cloth, for his subsistence till our return.

July 24: Could not start this morning till nine o'clock, in consequence of having lost a kedge with a hawser, the latter rather an indispensable article; after nearly three hours' fiuitless search, we moved onward on our voyage. Our progress was very slow to-day. In consequence of the strong current, we missed the channel and got into shoal water, touched twice, and were obliged to drop back, and anchored below Bullock Island. Mr. Richards went to find the channel. We passed a few villages on the right side of the river, and some large canoes from the market passed alongside of us. The country was open liere, and the wind was fresh and pleasant.

July 25: Got under weigh at about six A.r., and came opposite the group of villages of Ossamare or Awsimini, on the left bank. This place is said to be the resort of traders between Aboh and the Elugu and Isoama tribes of the Ibo country. If this be correct, taking also the open state of the country from this locality and upwards into consideration, it presents one of the best situations for a Missionary establishment among the Iboes. I shall make it a point to land and learn more of this place on our return. The great number of people along the bank to look at the steamer, tells the thickly populated state of this part of the country; and a great 
number of well-looking bullocks which were seen on the sand-beach, a little distance from those groups of spectators, speaks in favour of the industry of the people. I believe that from this the Bullock Island took its name. Steaming was slow and tedious, owing to a strong current and zigzag passage from point to point to avoid shallow water, and numerous sandbanks. A little after six we anchored off a district of Ibo villages, called Okoh, on the right bank; a lake of water was seen at a little distance before we came to anchor: the country is very open. We had passed two villages on the left bank before we came to anchor, for we steered on the right bank. The villages are Osutshi, and Akra Atani.

July 26: Started this morning about half-past seren o'clock, passed several groups of the people of Okoh, their villages being scarcely visible from the river, with the exception of a few fisling liuts. About ten A.M., some rocks were seen on the left bank, and the country began to present an undulating appearance. Shortly after, a group of about five hundred people burst into view in Onitsha market, on the left bank, trafficking by the water-side, with a great number of canoes; we steamed past them, as we were desirous, if possible, of getting to Adamugu before evening. Onitsha is the last market-town belonging to Aboh, on the left bank; a little while after we came to the Asaba market on the right side; they consider it the same as Onitsha, but no trade was going on, and about half-past two P.M. we unfortunately struck on a bank between Walker and Long Islands; we came suddenly upon it, having just sounded three fathoms, 
when the bow struck in four feet water: and with all the efforts we could make the vessel could not be got afloat that evening. Mr. Richards took the boat and went to sound about Walker Island, and returned late in the evening.

July 27: After breakfast, Mr. Richards went to take soundings again. At noon the slip was afloat, and at half-past one P.M. we got the steam up, weighed, and passed Ode creek on the left bank, where there were some canoes;-this place is said to belong to Abull. At seven P.M. we anchored opposite a place where the situation of the village Utò was pointed out, but it was not visible from the liver. 'The navigation of the river from Aboh to this place requires very great care in crossing from point to point, on account of many banks which stretch across the centre of the river, leaving the channel very close to the shore. It was on such a bank, sliglitly covered, that we struck after sounding three fathoms; many of them being visible to-day, we passed them more cautiously, by sending a boat a-head to find out the right cliannel: with this experience, we hope to be able to proceed more successfully during the remainder of our voyage. When the Expedition came out in $18+1$, eitlier these banks liad not accumulated, or they were completely under water as the river was much ligher then, so that the vessels went over all.

July 28: Weigled at six A.M., and in about an hour we came opposite the first village of conical liuts on the left bank, called Ommorlono, "Children's Cliildren;" it being the village of $\Lambda$ clamugu given 
by the Atta, or ehief of Idda, to his daughter as the inheritanee of her children. Mr. Riehards told me that Dasaba Nufi, king of Lade, brought his forces down to this plaee when he eontemplated attaeking the inhabitants of the Delta, to revenge the murder of Mr. Carr. I shall relate the partieulars respeeting Dasaba's expedition hereafter. We eommeneed speaking with the people here in Yoruba as well as in Haussa, because there are Yoruba and Haussa slaves in this neighbourhood. About nine A.x. we eame opposite the town of Adamugu, where one oblong and three round huts were seen near the water-side, on the left bank; the town itself being a little way inland. From Onitsha market to Adamugu, the banks presented at times the appearanee of mud walls, about six feet high from the water's edge. The interior of the eountry now and then assumed an open appearance. From Onitsha market to Adamugu the eountry is very thinly populated, and appears low and swampy in many plaees. We were steaming rapidly on, and every one was in hopes of getting near Igára this evening, when, unfortunately, we took a channel which had been bloeked up, and as we were returning to find another, the ship stuek fast in one fathom water. With all our efforts for the whole afternoon, she could not be floated off.

July 29: The labour of getting the ship afloat was resumed, but without sueeess till about four P.M., when she dropped down to the middle of the stream, and lay there at anchor. After dinner, a party of us landed on the beaeh of a sandy island, abreast of whieh we had grounded, to take a little exercise, 
while the ship was dropping down. We rejoined her about seven P.M. The country is open, and the weather cool and pleasant; the nearest village below us is Ami-Doko, a few miles above Adamugu.

Juily 30 : Sunday. As the men had laboured so very hard from Friday till late on Saturday, we remained quietly at anchor to-day, and had service at half-past ten. I preached from Matt. vii. 13. Several canoes came alongside, as on other days, to sell provision and cloths, but they were sent away, as it was the Lord's-day, in which we do no work. This they seem to understand as soon as they are told it, because $\mathrm{Mr}$. Beecroft in his many voyages up this river told them the same.

July 31: Got under weigh this morning at halfpast six. About nine we came abreast of Lander's Island, where the inhabitants of Oko Idoko and Abijaga, on the point of the first island, were seen on the bank, gazing at us as we passed. About five P.M. we anchored some little distance off Idda for convenience of wooding. Two messengers were immediately despatched to announce our arrival, and to tell thern that we would pay the Atta an early visit the next morning. This precautionary step was taken to remove every shadow of excuse from the Atta, that it was contrary to custom to see strangers on the day of their arrival in his country.

August 1: I had already told the gentlemen to prepare for a hard day's work, for it causes more trouble to see the Atta than any other chief we have yet met with: accordingly, we partook of an early breakfast, and taking some lunch with us, started for 
Idda about seven A.M. On landing we saw nothing of our messengers, but proceeded to the town, and there met one of the king's eunuehs, of whom we made enquiry eoneerning them. Without telling us directly where they were, he led us to the house of Ehemodiua, an elderly ehief, and a relative of the late Abokko, so favourably spoken of in Lander's and Oldfield's journals, and to whom the Landers were indebted for the preservation of their lives in their exploration of the Niger. Abokko's family has ever since been eonsidered, by righlit, the agent through whom all white men must be introdueed to the $\Lambda$ tta. In this plaee we met our messengers, who had been detained since last night, till messengers should arrive from English Island, where an army of about five luundred men were eneamped, to eneounter the party of one Agabidoko, their opponents. It was nearly noon before the expected messengers arrived, and from the severe rebuke one of them received from the chief, it appears that lie had delivered a wrong message. Ehemodina then told us, that we eould not see the king before to-morrow. We told him we eould not wait so long, as we were in a linury to ascend the river. He said he was in a diffieulty; for he did not like us to go to the king without the eonsent of Abokko's son, or else Abokko's name would be dishonoured. He then asked whether we should like to go to English Island and see Abokko's son there, that he might send some one to take us to the Atta, and promised himself to accompany us to the river side. To this we consented, as we liad 
determined to see the Atta to-day, and not be unnecessarily detained, and aeeordingly, Ehemodina ordered his old, but very poor white mare to be saddled. As we kept him briskly engaged in eonversation, he had no time to go in to dress himself for the ride, so he ealled for his dresses, and put them on where we were sitting, and started with us immediately. We had to retrace our steps nearly a mile to the river's edge, where we embarked for English Island, distant about two miles, to the point where Okeyin, Abokko's son, was eneamped with about five hundred men. We were led to his shed, and immediately eommeneed business. He wished us to stay till to-morrow before seeing the king; but we objeeted to this, and told him that we had taken the trouble to come to him, and to give him the honour due to him, that we mightit be able to aecomplish our objeet to-day. IIe thought it would be proper that the ship should eome near first, before we saw the $A$ tta. I told him that the ship was taking in wood, and we came to do business at the same time; besides this, it would make no differenee to the Atta whether the ship was near or far; for when Captain Trotter brought four ships here, thirteen years ago, and invited the Atta on board, he refused to come, because, he said, "the king never goes into a eanoe."* After a pause, he wished us to show him what we were going to give the king. I told lim it is not the white inan's fashion to show to others what he intends giving to his friend, and applied the ease to themselves,

* See Schün and Crowther's Joumal, p. 86. 
asking them, if $I$ were going to give a needle to any of them, whether it would be right to exhibit it to everybody. I added, that we did not know what we might be disposed to give to any person, until we lad proved him by the word of his mouth and his conduct; and that if he deserved it, I might be clisposed to give him the jacket off my back. Here they were put to silence. Otí, an intelligent-looking man, was immediately called to accompany us to the Atta, and Okeyin promised to get some eatables ready for us against our return; so we started again for the town, and took our lunch in the boat as we went along. Immediately on landing, we met a band of drummers and a fifer, who began to play; and Otí, the messenger, gave us a dance, flinging his sheathed sword in the air, which he caught with precision, and shook it towards us to signify what an expert man he was. This revived our party a little, for they seemed somewhat weary in walking up and down the hill of Idda from morning till the afternoon, while nothing apparently had as yet been effected. Otí led us again to the house of Ehemodina, from which place we started for the king's palace, nearly a mile further up the hill. After many zigzag turnings, and passing many low doorrways and porclies, which followed one another in a manner too irregular to be described, we were stopped at a small opening to await the Atta's invitation. It would be superfluous to state the inconvenience experienced from the closeness of the place, increased by the assembled crowd. Mats were at length produced, but the floor was so uneven 
that sitting was as uncomfortable as standing. A pot of bamboo wine was sent in for our refreshment, but it was so sour that none of us could drink it, and it was given to the spectators, who enjoyed it much. A calabash of good cold water was brought, which was refreshing. We waited about an hour and a half, I need not say with much impatience, but with this consolation, that the business once over to-day, it would not be repeated to-morrow. At last we received the welcome message that we were called in by the Atta. We found him sitting outside the verandah of the palace, on a mud-bank overspread with cloth, with an old carpet at his feet; on the carpet were placed his royal message sticks, with brass bells attached to them; and an old broken Souter-jolnnny jug stood before him. He had on a silk velvet tobe, and a crown of white beads, fringed with red parrot-tails in the front, with other fanciful decorations. Ilis neck was covered with a large quantity of strung cowries, and coral and other beads. It was the same Atta visited by Captain Trotter in 1841. After the usual custom of paying and receiving homage from his subjects, he asked the Europeans to shake liands with him, which they did; after which, I and Mr. Richards were asked to do the same; we then took our seats. He expressed his joy at seeing white men in his country again. We communicated with him through the medium of IIaussa and Igára interpreters; Aliheli interpreted for us in Haussa, and one of the Atta's men, who spoke Haussa, repeated the words to him in the Igára language. Dr. Baikie 
having instructed me what to say, because Aliheli could understand me better, I commenced by reminding the Atta of the visit paid to this place thirteen years ago by four ships, and told him that Captain Trotter was still living; that the Queen, who sent Captain Trotter at that time, has now sent Dr. Baikie, accompanied by Messrs. May and Dalton, to ask after his welfare, and to see whether the country is at peace, and the $\Lambda$ tta as well disposed now as at that time; that the Queen has not forgotten lim, nor the treaties she had made with him through Captain Trotter. He replied, that he remembered Captain Trotter's visit perfectly well, and that all things remained just as they were at that time. He was reminded that Captain Trotter had promised that traders would be sent to deal with him. Dr. Hutchinson was then introduced as a merchant who was come to trade with him; upon this he ordered his attendants to give shouts of approbation, and expressed lis great joy at the news. He said the place which Captain Trotter liad selected for a trading establishment at the Confluence was not a suitable one, being too much out of the way, and liable to be disturbed by the Filatis; and that lie would rather advise the merchants to establish themselves at Idda, or at Ikiri market, which is so near that when a stranger was living there, he would be able to send a messenger every morning to ask after his health, which he could not do if he lived at the Confluence. I admitted the truth of what he said, but told him to consider that white men are very sensible, and always take right steps to accomplish their objects. I asked if any per- 
son were to be troubled with boils on his foot, whether it would alleviate the pain, to apply salve to his head? He replied, No. I said,-Well, in order to prevent future disturbance by the Filatas, the Queen has sent some gentlemen to go by land from the north to the Sokoto, Bornu, and Haussa countries, to make treaties of peace and commerce with those nations, and to tell them, that not only they, but all the countries on the banks of the Niger and Tshadda, such as Ibo, Igára, and Nufi, are their friends, and that they should not be disturbed. To this they all gave shouts of approbation. $\mathrm{He}$ was told that two of those gentlemen were in the interior, and that the ship would start to-morrow to meet them and take them on board. When the Atta heard that the ship would start to-morrow he was displeased, and said it must not go till some trade was done here first. I then asked him how he thought a man should act when he hears that his companion is carrying a heavy load on his head, and is weary of his journey? Would he say, let me first go to the market and sell all my goods, before I go to meet and help him? He said, No. I told him the case of our friends in the interior was just so. He then urged for five days stay, alleging that the water has not yet covered all the rocks; and promised to send some one to accompany us. He was told that it was better for us to go higher up before the rocks were covered, and that if we stay later, the water will not wait five days for us when it begins to subside. He at last pressed for to-morrow, as he had something to trade with, and eventually six hours, 
that is till noon, was promised for this purpose. I next reminded him of another subject Captain Trotter had brought before him, namely, whether he would allow his people to learn the white man's book, and to embrace their religion, as they teach it in other countries; telling him that I was particularly sent to ascertain his disposition in this respect. He said, he remembered the proposal, and was as willing as before. The presents were then given, and about half-past five P.M., as it threatened to rain, the Atta withdrew, and we returned to the water-side just before dark, much satisfied at having accomplished this most disagreeable task. The political state of Idda at this time, like other places, is becoming confused by divisions and party quarrels. This proves that the power of the Atta is waning, and he may not be able long to retain his authority over a great part of his subjects, if these party quarrels are not soon put an end to. Since the death of Abokko, so frequently mentioned by the Landers and Oldfield in their journals, the town of Idda has greatly suffered; a great portion of the population, chiefly Abokko's party, have left Idda, and parts of the town they used to occupy are overgrown with luxuriant grass, which gives the town a very deserted appearance. Those who left the town are residing all along the left bank, from Adamugu, a great way towards the Confluence, hence the number of villages which go by the name of Abokko, or some one or other of his children. It is said when the present quarrel is settled, Okeyin and his party will quit the town of Idda. 
The present dispute, which caused Okeyin to encamp on English Island, is thus related:-Some quarrel originated at Asaba market near Onitsha, with one Agabidoko, whose father was an Igára by birth, but his mother an Ibo. Agabidoko's people, for some offence given, attacked Abokko's people in the market, when several of the latter were wounded and killed. By way of retaliation, Abokko's people seized a wife of Agabidoko, and kept her in custody at Idda. Aje undertook a journey of ninety-five miles from $\mathrm{Aboh}$ to settle the matter, but he could not obtain an interview with the Atta, though the path was cleared for him from the palace to the water-side. It would seem that as Abokko's people are the most powerful at Idda, the Atta was afraid to offend them, but whatever might be the reason, Aje had to return unsuccessful. A few days after Aje's return, Agabidoko's people made war against Abokko's people, but had a bloodless battle, the latter being on the island, and the former on the river, and on their departure they took five Idda canoes away with them from the water-side; -in this state the matter still remains. When we were waiting at Ehemodina's house, he expressed his wish that we should interfere in settling the matter between the two contending parties; and he was told that, if the $\Lambda$ tta should seek advice from the commissioned officer, or request him to act as a peace-maker between them, he would have no objection to do so. But the king never said a single word on the subject, and even when particularly asked whether the town and country were at peace, he answcred in the affirmative. 
August 2: As we could not call at English Island yesterday to report the result of our interview with the Atta, we sent the messenger to tell Okeyin that we would call on him when the ship came near in the morning. We anchored close to the town, at the point of the cliff, to land some coals and to trade with the people till noon. A great number of people soon cane alongside, and the 'Pleiad' was full of them. I accompanied Dr. Baikie to English Island with some presents for Okeyin, Ehemodina, and Otí the messenger. In return, Okeyin gave the Doctor two goats, and about forty yams, and we returned on board. Two of the Atta's danghters came to see the ship; they were shown into the saloon, and something was given them to eat, but they were too bashful to partake of it. Otí took care to wrap it up carefully for them to take away; and they received presents from Drs. Hutchinson and Baikie, and I alded two small glass plates, sent me by Lady Buxton, with which they were highly pleased. At half-past one P.M. we weighed, and steered very close to the cliff on which the town is situated, which presents a very romantic appearance, and is said to be about one hundred and fifty feet above the river. We proceeded about ten miles, and experienced some difficulty in finding the right channel; getting frequently into shoal water, from banks being a-head in various directions, in consequence of old channels being blocked up and new ones formed. Mr. Richards took the boat to sound, when the ship dropped anchor for the night. August 3: Got under weigh about six A.M.; 
and after some difficulties, we at last found the right channel, and made a good progress, the river becoming more contracted, and consequently deeper. We anchored abreast of Soracte mountain for the night. The people showed some timidity at first, but by persuasion they came on board with some ivory. The left bank of the river is now more thickly populated than in $18+1$. In consequence of the invasions of the Filatas, all the inhabitants of the right side have removed to the left, and built their houses upon the mountains as places of refuge. The right bank is more easily accessible to those marauders, but they would have difficulty in crossing the river before they could gain access to the mountains, as their chief strength lies in their many horses with which they chase this poor and defenceless people. No one who beholds it can conceive how this mountainous country can be unhealthy; the wind was fresh and pleasant, and every one seemed to enjoy it much. Many rocks which were covered when we were here in September 1841, are several feet above water, which shows that we must yet expect a greater rise of the river than at present.

August 4: Got under weigh as usual, but when not more than a mile from the Confluence, the 'Pleiad' struck on a bank immediately after sounding three fathoms, opposite the town of Igbégbe. While they were heaving her off, Dr. Baikie, Mr. May, Mr. Richards and myself, landed at the town, to see the chief and collect some information. WVe were led into the house of Ama-Abokko, the principal chief in this district. $\mathrm{He}$ is the eldest son of the late 
Abokko of Idda, and brother of Okeyin, who was encamped on English Island. Ama-Abokko received us very kindly, and admitted us to the back piazza of his private apartment, where he seated us; and we told him the object of our visit to the Niger at this time. Ama-Abokko was not at this place when the Expedition was here in 1841, and the town was very small then; but since Dasaba's invasion of the right bank, a great many of the inhabitants of that part of the river have fled to this place, and to other localities on the left side, for security. The inhabitants of Mount Patteh were obliged to give up their stronghold, because Dasaba disturbed them for two years. Ama has not received any intelligence about the white men who are travelling in the interior. From him we learnt, for the first time, that Panda (Fundah of Laird) was destroyed by the Filatas only three months ago, that the king was killed, and that the Filatas were about Toto, for whose safety he expressed much doubt. At our request he promised to send some messengers with us to tell us the names of the villages and places on the banks of the Tshadda as we ascend; and we invited him on board the next morning. Here also was confirmed information which we had received at Adamugu, that Dasaba was driven out of Lade by his brother near Rabba, because the Nufi people preferred him to Dasaba, the latter being too tyrannical for them, and putting many people to death unmercifully for trifling offences. Dasaba has fled to Ilorin for refuge.

Mr. Richards, who accompanied Mr. Beecroft to 
Rabba in his last visit to that place in $\mathbf{1 8 4 5}$, iuformed me, that Dasaba had told them when at Lade, that his expedition towards the Delta, was to revenge the death of Mr. Carr; that king Obi of Aboh had sent to inform the Atta of Igara of the conduct of the inhabitants of the Delta, who had killed the white man coming to establish trade with the upper country, and that something must be done to keep the road open for free communication between them and the white men: that the Atta not having sufficient power to do this, scnt to him as one concerned in the matter, and powerful enough to keep the road open; and that he promised to bring a large force of horse and foot, provided the Atta would furnish canoes to take them across the creeks and rivers. Accordingly Dasaba brought down a large force, and encamped for a considerable time at the model farm : the Kakandas joined his army, and they marched downwards as far as opposite Adamugu, when Dasaba commenced his attack seaward; at which time about one hundred towns and villages were destroyed, but being afraid of losing many of his men and horses in the swamps, he returned. But as they have no principle to restrain their cupidity in time of war, the remainder of the Kakandas who had not takcn timely warning to flee for safety to the left bank out of the way, fell a prey to Dasaba's soldiers on their way home. Thus nearly all the right bank of the Niger, from opposite Adamugu to the Confluence, has scarcely a village to be scen, while the left bank is full of new and extensive towns and villages, which were not there in 1841 . The very 
mention of Dasaba's name is odious in the ears of the natives about the Confluence.

August 5: Started early this morning with Drs. Baikie and Hutchinson, and Mr. May, to go to the top of Mount Patteh. Mr. May wished to sketch from that elevation, of about twelve-hundred feet, the juncture of the Kowara and Tshadda, but owing to the desolated state of the country, the valley was so overgrown with wood and high grass, as to be impenetrable, except where we came upon the track of elephants, now the undisturbed possessors of these once thickly populated districts. As we could not go on because of the thick grass and swamps, we returned to the boat and pulled further up, till we came to a landing-place, where a small canoe was seen under the trees, belonging to a small village of eight or ten huts, a scanty remnant of the once secure villages of Mount Patteh. This village is built on the first cone, about a third part of the way up Mount Patteh, where very old persons only were living. We asked them the way to the mount, but they told us there was no way thither at this time, as Dasaba had driven or carried all the inhabitants away. The sight of these villages was truly pitiable. They pointed to the site of the Model Farm below, which is now covered with trees and grass, and asked if we were coming to rebuild it. I told them it might be taken up again in due time. They entertained us, according to their means, with country beer and clean cool water, which they fetched from the side of Mount Patteh. We promised to give them some presents if any of them 
would come on board, and returned to the ship about ten A.M.

Ama-Abokko, the chief, had come early on board, and Captain Taylor had been talking with him about trading affairs till our return. Dr. Baikie called him into the saloon, and gave him some presents from Government, with which he was much pleased. We tried to get him to forward letters to the coast for us by way of Ilorin, Ijaye, Ibadan, and Abbeokuta, but he made so many excuses, that I evidently saw he was afraid to do it, though he did not like to say so, for fear of cornmitting himself, because people might accuse him of sending a bad book or charm through Ilorin, as Dasaba their common enemy has taken refuge there; and he did not sufficiently know us and our footing on that part of the coast. We reminded him of the person he promised to send with us, and told him also, that we would hire some of his canoe men, if he would let us have some, to which he consented, and raised our expectation as to his readincss. Ama-Aboklko styled himself the king of this part of the country, and I tried to ascertain whether he was indepondent of the Atta, but could receive no satisfactory reply to my question. I dare say he did not like to tell us. That we might see more of the town and collect information, we went after twclve to Igbégbe, each one in a different directicn, except that Mr. Richards and myself went together. Ivory was shown us as well as trona, (salt packed up in grass bags from the coast,) horses, and two slaves. I offered to purchase one of the owners herself, instead of the slaves, but she shuddered at the idea. I left 
her to infer from that the propriety of dealing in our fellow-men. Some slaves were in a canoe alongside the ship to-day. It is not to be wondered at, that many slaves are seen about just at this time, for many unfortunate persons who have suffered in the war between Dasaba and his brother, and such as have fallen a prey to the Filatas at the destruction of Panda, are now scattered about the country in all directions by their captors. Fortunately, they must remain in the country, as there is no place known in the Bight of Biafra for exportation of slaves, the only foreign slave-markets being Whydah and Porto Novo, in the Bight of Benin.

From the town of Igbégbe is visible that of Patta, about two miles distance. There are two places of this name, the first, near the left bank of the Tshadda, the other, between the first Patta and Tshewu. The first Patta and Tshewu are at war with Igbégbe, and soldiers come by stealth from them and shoot people, or catch them at Igbégbe and run away. I believe these two Pattas are inhabited by the people of Mount Patteh, who have taken refuge on the banks of the Tshadda. The chief, Ama-Abokko, never mentioned the circumstance of there being war between them, but always said there was peace. We returned on board about sunset.

August 6: Sunday. Had service on board at half-past ten: preached from 2 Tim. i. 7 , on the former part of the text: "God has not given us the spirit of fear," and applied it to individual members of Christ's Church, but I preached in much weakness ; may the Spirit of God carry His word home 
to the heart and consciences of those who heard it! The people here speak the Igbira language, and we had no one who could speak directly to them. Our communication was carried on, either through the medium of Yoruba or Nufi, or through the Haussa language, before it was interpreted to the chief in Igbira. As this mode of communicating is a very inconvenient one, I was afraid of making use of persons who have not the least idea of the spirit of what I intend to communicate; and to attempt to convey any notions of the Christian religion through such channels would, I feared, lead to misconception. There are but few traders and inhabitants who can speak Haussa, Yoruba, or Nufi: the people in general speak the Igbira language.

The people were told yesterday, that to-day would be Sunday, or our sacred day, in which we do no business. They did not, therefore, come for trade, but a few small canoes brought beer and some eatables, which were purchased by the Krumen. 


\section{CHAP. II.}

ENTRANCE OF THE TSHADDA-SINCERITY OF AMA-ABOKKO-THE FILATAS-DESTRUCTION OF PANDA-IYANPE-THE BASSA COUNTRY AND LANGUAGE- CONSULTATION ABOUT TURNING BACK-PASS DAGBO, THE TERMINATION OF FOHMER EXPEDITIONS-DOMA-BLIND REFORT OF TWO WHITE MEN IN THE NEIGHBOURHOOD-THE MITSHI TRIBE-ORIGIN OF THE CHARGE OF CANNIBALISI-IGARA TRADITION-DETENTION AT OJOGO-CHARACTER OF ZURI-KEANA AND ITS KINGARRIVAL OFF ROGAN KOTO-SUSPICION OF THE NATIVES AT GANDIKO AND GANKERA REMOYED BY CONFIDENCE.

August 7: Having laid in a sufficient stock of green wood, we got under weigh about eight A.M., under green wood steam. The channel was very intricate:-after a long zigzag passage at the mouth of the Tshadda we got into four and five fathoms water, with very slow progress, and hardly made eight miles direct from the Confluence, because the steam could scarcely be kept up for an hour together, and the anchor had then to be dropped while it was got up again.

August 8: About eight A.M. we weighed anchor, but in about a quarter of an hour the steam failed, and we were obliged to drop it again. It was impossible to accomplish our object at this rate, two days having been wasted merely for want of proper fuel to keep up the steam; and if the Krumen were sent on shore to cut wood again, it would be as green 
as before. Dr. Baikie, therefore, inyself, and Mr. Richards, landed at a small village called Atipo, a little way higher up, where we saw plenty of dry wood in the town; we told the natives to take it to the water-side, and returned to the ship to tell Captain Taylor of our discovery, and to know if he would purchase it. One of the iron canoes was soon paddled thither, and in about three hours she returned deeply laden with dry and substantial firewood, which we hoped would enable us to move onward in our voyage. Several enquiries were made to-day of Dr. Barth, but no news was heard of him. In the evening a canoe came alongside from Ama-Abokko with seven persons, two of them being headmen; one of the headmen, Zuri, sjoke several languages, and was a native of a town on the bank of the Tshadda, which pays tribute to Panda, and also to Wukari. This man will, we hope, be of great use to us as we ascend the Tshadda. We lrad thought that Ama-Abokko was not faithful to his promise, but we were wrong; and his sending his own canoe to overtake us after two days' sail from the Confluence, against a strong current, corrected our erroneous surmises as to his sincerity, because he was not able to fulfil his promise at the mounent we looked for it. The native chiefs always take more time to think and arrange their plans and settle their affairs than we are aware of. We are very thankful to have these men with us, speaking Igára, and Igbira, or Panda, they being natives of the banks of the Tshadda, and as Zuri can speak Ilaussa, we hope to be able to collect much information. 
August 9: Got under weigh about half-past eight A.Mr., and anchored abreast Little Harriet Island at six P.M., the steam having been kept up sharp and brisk under a mixture of dry and green wood. The Tshadda presents in appearance the same expansive sheet of water, as did the streams of the Kowara and Tshadda united, and contains a good depth of water, and has been of easy navigation hitherto. The cliff on the right bank of the river, on which the village Ogbá is situated, is covered with luxuriant jungle, called Frenchwood in Allen's chart of this river. The name of the inhabitants on both sides of the river is Igbira, to whom the land of Panda belongs. The Atta, many years back, sent one of his sons to reside at Panda, which was tributary to the king, and this son ultimately became its sovereign. The boundary of Panda, in other words, of the Igbira country, is between Oketta and Abatu, the latter being the first village belonging to the Bassa country near the river side. Here we began to meet recent traces of the $\mathrm{Fi}$ lata depredations; the inhabitants of Ogbá, on Frenchwood cliff, were obliged to take refuge on Harriet Island, on account of the Filatas, fearing lest, after the capture of Panda, they might attack them also.

August 10: Started about eight A.M., and arrived at Yimaha, on the right side, about noon, where we dropped anchor to get wood. Here again the inhabitants have been obliged to quit their town, and to take refuge on the opposite island, where they have built temporary sheds to escape the depredations of the Filatas; who, not content with the destruction of Panda, and molestation of Toto, 
covet the poor and defenceless inhabitants of Ogba and Yimaha in their avarice. We landed on the newly inhabited island, in which there must have been a thousand people. We were led to the quarter of Ozineku, their chief, a very aged man, seventy years old, if not more. We told him the object of our visit, and made enquiry after Dr. Barth, but no intelligence could be gained. Dr. Baikie told the chief to send inessengers on board, that he might give him some presents. Leaving the island, we landed on the right side at the town of Yimaha, which was deserted three months ago. Here we met a few men who were keeping a look out for the enemy, and at the same time were occupied in the process of dyeing their cloth blue; an art, which is professed by men in this part of the country instead of women, as in the Yoruba country. Upon landing we saw recent traces of the Filatas; only last night, a liorseman and six foot soldiers were sent to see if the inhabitants of Yimaha could be easily taken away. The spies finding the town deserted, went through it, even to the water's edge, where they stopped some time - quite recent traces of their horses being visible. One can better feel than express in words the distressed state of these poor people, who are continually harassed and hunted by the Filatas, the greatest pests of this part of the country. They will not work themselves, and those who will they disturb and seek to enslave, eating up at the same time the fruits of their industry. The hunters of elephants and collectors of ivory, are either killed in their attempt to defend their 
country and families, or are prevented through fear from going about their lawful occupation; and thus not only is the country disturbed, but the European markets are left unsupplied. The men led us to the house of the chief, and told us that the gentlemen of the former Expedition resided there. We presumed that Messrs. Lander, Laird, Oldfield, and Allen, were meant, who were here in $1 \succ 32-34$. While wood was being bought, some tusks were purchased also. We weighed about half-past four, and anchored above Potinkia (Potingia) creek for the night.

August 11: Got under weigh about half-past eight A.M. Before noon we were in shallow water, and grounded off a small village, called Kende, on the left side, but the vessel was got off again after a little exertion: a part of the engine, however, called the donkey, was damaged, so that we could make no further progress for the day. In the afternoon we landed at Kende, where some of the few who escaped seizure by the Filatas at Panda have taken refuge. Here again is a picture of the misery these poor people are doomed to go through; for they live destitute of every thing, having escaped with scarcely any thing but their liberty, and that with difficulty. The Filatas, whose aim is not so much to kill as to seize and enslave, took Panda by treachery. They professed friendship, and entered the town on that pretence, and the king presented them with bullocks and other necessaries; but when a sufficient number had got in, they commenced seizing the inhabitants, and scarcely gave them time to make resistance. Only the king, Oyigu, and a few persons about him 
made any effort to repel them; but the king could not long stand against his enemies, and was killed in the attempt. A great number were caught, and very few were so fortunate as to escape. The neighbouring towns and villages were immediately deserted by the inhabitants, who took refuge on the left side of the river. Here we met with a son of the clief of Potinkia (Potingia), who remembered having seen the white men on their visit to this river many years ago. We find the usefulness of having Abokko's men with us; the people would not come near us, until these men had told them who we were, and assured them that they would not be hurt. 'They then took confidence and came on board.

August 12: After breakfast I went to the beach with Dr. Baikie and Mr. May, to receive a lesson from the latter in taking observations. Captain Trotter was kind enough to send me a quadrant by the "Forerunner" for the purpose, and I hope it may be of use to me hereafter. In the afternoon we went to the village and distributed a few cowries among the poor inhabitants, who were very glad to receive them; a few yards of unbleached calico would have proved a great boon to them, if I had had any to distribute among them. Dr. Baikie amused the children by strewing some cowries, for which they scrambled.

August 13: Sunday. Preached from 2 Tim. i. 7., the latter part of last week's text. May the Spirit of God apply the word to each and all our hearts.

August 14: Got under weigh after breakfast 
There continues to be a good depth of water, though the channel is at times intricate. The villages which we passed to-day are called Iyanpe on the right side, and Irigi further inland, and others, not seen, are called Betikia and Lesebu. Three villages are known by the name of Oketta on the right side, but the inhabitants have taken refuge on an island opposite for fear of the Filatas. A little while afterwards we came opposite the neat village of Amaran, on the left side, situated on the east side of the foot of Mount Pleasant, very appropriately so named. The village of Amaran could not have been there when Mount Pleasant was named, or it would have been noticed. We anchored alureast of Bay Island for the night.

August 15: This morning we spied a few natives in a small opening in the bush on the right side. They were armed with bows and arrows, in readiness to repel aggression. Ama-Aboklzo's messenger called to them, as they were within hearing, to persuade them to come off, but they would not; he said they were Bassa people, whom he called Kaferi-wicked archers, who had hired the Filatas to destroy Panda, and are, therefore, held in great hatred by the Igbira and Panda people, to whose king they were tributary. This marauding tribe have destroyed towns and villages in Panda, and even to the westward of Panda, beyond the confines of their own district, which lies to the eastward of Panda.

The Bassa language is very much like the Nupe, with some little variation and peculiarity, as may be seen in Mr. Koelle's "Polyglotta Africana." " The

* "Polyglotta Africana; or, a comparative Vocabulary in 
village of these Bassas, abreast Bay Island, on the right side, is called $A b a t u$, but it is not visible from the river. Here is said to be the beginning of the Bassa country. Three or four miles from our anchorage brought us to the village of Abatsho, on the left side of the river; here we anchored, and invited the natives on board. Three ehiefs eame off, whom we found to be Irobo, Itshigbasa, and Allagaba-the two former were sons of the late old king of Panda, Abuha, who was visited by Mr. Laird;-Allagaba was the elief of Potinkia. They were all taking refuge here on aeconnt of the destruction of Panda. Abuha was suceecled by his brother, Adekke, who reigned thirteen years, when Oyigu, who was latcly killed by the Filatas, became king. Irobo has now taken the headship of the village of Abatsho. Enquiry was made of Dr. Barth, but nothing was heard of him; but they told us that in all probability we might hear of him in Akpoko, a village near the river, in the eountry of Doma, where Hanssa people eome to trade from the interior. Presents were given to these poor chiefs who were very glad to reeeive them. I eneouraged them to hope for better days, and said that though the Filatas, their near neighbours, prove to be their enemies, yet God will raise them kind friends and well wishers in white men from a far eountry. A Haussa woman, named Asatu, came on board, and was reeognised by Mr. Richards as one of the traders who used to be employed by Mr.

more than one hundred distinct African Languages," by the licv. S. W. Koelle, Missionary of the Church Missionary Society. London, 1854.

ग) 2 
Beecroft, and who used to receive goods in large quantities at the Confluence, to sell for shea butter and ivory, when Mr. Beecroft ascended the river. She was very glad to see a steamer up the river again. Dr. Baikie gave her a looking-glass. We weighed from Abatsho, and anchored a few miles higher up.

August 16: Got under weigh as soon as steam was up. The passage continued intricate; we had nearly reached Oruko, when we fell into shoal water and were obliged to drop astern to clear out of it, and anchored till the channel could be found. Afterwards, several attempts were made to proceed, but without success. The Bassa people, who had been driven from their towns by the Filatas, have taken refuge on the island, and on the left side of the river. They were exceedingly timid, and no wonder the sight of so large a body as the steamer on their waters was enough to frighten them, as they have alreary been placed in continual fear by the Filatas, the enemies of all.

August 17: After nine A.M., Captain Taylor, accompanied by Dr. Hutchinson, and Mr. Guthrie, the chief engineer, went to sound the river, and did not return till the evening. The captain declared it was impossible for the ressel to proceed further. On this Dr. Baikie, wishing to persevere in the attempt, took entire charge of the ship. It would have been a great pity not to have gone further, as we had come thus far, and were still eight or ten miles below Dagbo, the furthest point reached by Oldfield and Allen; so that the new 
ground to be explored by this Expedition would only commence from that place. The health of all in the Expedition having been so mercifully preserved hitherto, every one felt a desire to go onward as far as practicable.

A ugust 18: Dr. Baikie having now charge of the ship, ordered the steam to be got up, and about seven A.M., we were under weigh, having sent Mr. Richards previously to sound the channel. About ten A.M., we passed the most intricate part of the river, opposite the town Oruko, whose chief Adama, is said to be king of all the Bassa country. He sent one of his sons with a goat to Dr. Baikie for a present, and wished the ressel to stop and tracle with him; but said that he had only tell tusks of ivory to sell, the Filatas having wasted all his property at the destruction of the country. Dr. Baikie sent him a message to wait till our return, when we hoped to pay him a visit, and trade with him also. Some presents were sent to him by his son, with the message, that he should warn all his suljects never to molest any white man's boat or canoc that may be passing up end down at any time through his waters. This message was necessary, because the Bassa people are much clreaded by native traders, on account of their thicvish propensities. About noon, we anchored off Dagloo, the termination of Oldfield's and Allen's exploration in 1832 - 34, where we remained and wooded during the evening. The old town, Dagbo, appears to have been deserted, and the inhabitants have removed close to the river, to a piece of land nearly surrounded by a ereek, which affords them good 
security against the ravages of the Filatas. Dagbo appears to be the begiming of the Doma district and language. The seattered groups of huts which form the village present more the appearance of farmhouses than anything else. A great extent of land has been cleared, and planted with Indian and Guinea corn for the people's sustenance. They are very poor, and consequently had nothing to trade with.

August 19: Mr. Richards was sent early this morning to sound the channel, and as soon as steam was up, we got under weigh and followed. After much perseverance we cleared the intricate channels, and got into a fine sheet of deep water extending to a considerable distance, when we came again amongst groups of islands, which occasioned frequent shoals. We passed the villages of Egy and Igere, on the right side, Agatu on the left, and Joko, on an island. These people are called Kaferi, or "wicked archers," from their disturbance of the water passage. About four P.Y., we anchored off Akpoko, a very sinall village in the valley of the Doma hills. The ship touched the ground several times, but was always got off by backing the engine, or by the men going aft and dancing her off. As soon as the ship came to anchor, Drs. Baikie and Hutchinson, Mr. Dalton and myself went on shore. The town is accessible through a fine open creek at the foot of the hills, though invisible from the anchorage. The people at first showed some timidity, having never seen white men before; but when Zuri spoke the Igbira and IIaussa languages to them, they became confident. Many of 
the people understood Igbira as well as Haussa. On landing, we were led into the chief's house, where we stood outside for a few minutes, till he came and invited us in. He was an old man of small stature, but respectable appearance. He was dressed with a decent country cloth around his waist, and wore a country shirt of patchwork yattern, of blue and white, cut in triangles, of native manufacture and workmanship, except the fringe on the borders, which was cut out of red woollen cloth of European manufacture. He had a red Turkey cap on his head. Mats having been spread for us, after the usual salutation and customary compliments from Zuri and Mahamma, our interpreters, they delivered the message of Ama-Abokko and introduced us to the clief. Dr. Baikie told him the object of our visit, and made enquiry after Dr. Barth, of whom we expected to hear news in this place. But no intelligence of any European traveller has reached this country. Magaji, the chief, acknowledged that Doma is subject to Bello of Sokoto; but, as governor of the water-side, he would acknowledge no superior, and said that every chief rules his own district, of which there are many in Doma. He answered questions respecting the government of the country witl much reserve, especially respecting the Filatas; which shows, I think, that if it were possible, they would eagerly throw off the Filatas' yoke. We wanted to know the distance of Wukari, but received no satisfactory reply.

No sooner was the subject of trade introduced, than six tusks were immediately produced, and 
Magaji was very anxious for the ship to wait till to-morrow, when he promised that plenty more should be brought. But as Dr. Baikie had determined to start early to-morrow, so much time having been already lost, they were requested to send on board what they had in hand. Nine or ten tusks were brought and purchased that evening. The chief is saluted by kneeling on the ground, the forehead is inclined, and two fingers of botl hands are rubber in the dust, and dust rubbed on the forehead several times. The people salute one another by embracing, the right hand of the one being stretched parallel with the left of the other as far as the shoulders, or with both arms occasionally. The religion of the place is Paganism, for there were some fetishes under the trees, in front of the chief's house. The village comprises no more than forty conical huts, including the granary; and yet it is fortified with a ditch about twelve feet deep, and mud walls. The gate is entered by a drawbridge of three poles laid across, and is rather dangerous for passengers.

August 20: Sunday. Got under weigh at six A.M., the river much improved, there being fewer islands. Before ten, the vessel touched immediately after sounding the great deptl of seven fatloms; she was hove off by backing the engine, together with the exertions of the men walking aft and dancing. We anchored, and had service at lialf-past ten. From constant excitement in entering an unexplored country, and other canses, which occupied much of uny time, I could not complete my sermon: I therefore read the first and second parts of the nineteenth 
Homily on Prayer, the subject I had taken in hand for the week. The most disagreeable effect of sailing on Sunday is, that it keeps the Krumen continually at work, cutting and splitting wood for fuel from morning till evening, together with frequent touching in shoal water, when all hands must run aft to dance the ship afloat. This interferes much with the sacredness of the day. When I thonght how mercifully we had been preserved since our entering the river, now five weeks, no European having been laid up for a week, I could not free my mind from the apprehension of our incurring God's displeasure by distrusting His providence, in thus desecrating His holy day, in order to accomplish our objects, how noble soever they might be. In the afternoon, we got under weigh and passed the villages of Otia on the right side, and Aghadumo on the left, and Ayati and Zuwo on the right. At the approach of the steamer, the inhabitants of Zuwo quitted their village, and no trince of human beings could be seen, except the goats and fowls which they lad left behind them.

August 21: Got under weigh about six A.Mr. After touching several times in shoal water, about two P.M. the ship ran aground; but with much exertion she was got afloat and anchored for the night. The country appears very thinly populated hereabouts. If this appearance arose from the fear of building too near the banks, because the river overflows them every year, we should have seen, at least, landing places as we passed along, but there was a total absence of such. The villages actually seen were 
very few, compared with those on the lower parts of the Niger, or the Kowara branch. The country, for the most part, is open, though at times wooded, and occasionally clusters of fine lofty palm-trees occur, which show, by the old branches or leaves hanging down from the head of the trees, that the natives do not trouble themselves to gather the nuts for their use. Scarcely any trace of cultivation was seen along the banks, to relieve the eye. In the night we had a heavy shower of rain, accompanied with thunder and lightning, which cooled the atmosphere, for the sun had been oppressively hot of late, and the river had fallen considerably. We had had no rain, till last night, since we left Idda three weeks ago.

August 22: Got under weigh about six A.n., and after many slight touchings and hearing off by backing the engine, at 12 A.M. we ran into shoal water, and grounded about a mile or so below the village Ojogo, to which we liad been looking forward as a place to anchor at, and get wood for fuel. With great efforts the ship was got afloat by half-past six P.M., but could not clear the shoal that evening. It was with much persuasion from Zuri, our interpreter, that the natives were induced to come on board; two or three canoes afterwards brought some wood and fowls, which were purchased from them. Their canoes are very small, and are propelled by large long paddles, in a standing posture. We made enquiry of Dr. Barth, but obtained no intelligence.

August 23: Early this morning the chief of Ojogo sent messengers to enquire after our liealth 
and to show us the channel; but as they had no idea of the draft of our ship, their offer was not accepted. While the steam was being got up, Mr. Richards was sent to sound the channel; and on his return about eight A.x., he brought the welcome tidings, that on his making enquiry, he was told that two white men were not far from this neiglibourhood, in a town called Keana, about four days' journey to the northward. I need not mention that every one on board was much rejoiced by this intelligence. We got under weigh, and after much trouble, the ship cleared the shallow bank, where we had been actually locked in. In a short time afterwards we anchored off the village Ojogo, situated on the point of an island, on the right side, formed by a creek which separates it from the main land. We immediately sent messengers to inform the chicf of our arrival, and that we would pay him a visit soon. On the return of the messengers, we mide ready for the village, but a great many of the inlabitants, and especially the females and young persons, were terrified, and fled from the village into the bush anong the palm-trees. The men were armed with bows and poisoned arrows, and sone with long spears: the latter formed an eseort to lead us from the beach to the village where we inct the chief sitting almost alone, under a large tree, which afforded an agreeable shade, outside the group of huts which formed his residence. $\Lambda$ fter salutation by shaking of hands, Dr. Baikie introduced the subject of our visit, and expressed his wish to send immediately to the white inen, who, we heard, werc at Kcana. Our 
previous knowledge of the case gave no room to the chief to plead ignorance, and he promised at once to confer with his headmen, and let us know, when we had returned on board, about sending messengers. In the mean time we had the man on board who had informed Mr. Richards of the travellers being at Keana. He confirmed his statement, that they had arrived there one month before he left Keana, and that he had seen them eight days ago, and offered to go with the messengers if he were serit; he himself being a native of Keana, where his father is living, but his mother resides here at Ojogo. We gave him some presents, and held out hopes of his getting more if he would go with the messengers, and bring our friends down. The pictures of the four travellers were shown to him, from the frontispiece of Petermanu's Atlas of Central Africa. He looked for awhile, and pointed to that of Dr. Barth, which he said was like him in countenance, but he missed his beard and whiskers, like those of $\mathrm{Mr}$. Richardson; he pointed to the picture of Vogel as his companion. From these and other testimonies, we concluded that the information was likely to be true.*

As the chief's messenger was not forthcoming, we sent to him again in the evening, to express our disappointment. The messengers returned, and said, as he was the chief of the water side, he wanted to catch some fish first, to send to the chief of Keana, who was his superior, and who would be displeased

* It will be seen, howerer, from the sequel, that the informant wes misunderstood. 
if such a present were not sent to him. To-morrow morning, Dr. Baikie and myself intend to go on shore and to push the matter forward. In the night we lad a heavy tornado and rain :- the river may now be expected to rise.

August 24: Early this morning we went to visit Amishi, the chief, about sending the messengers to Keana without delay. We succeeded in putting aside the plan of catching and sending fish to the chief, by promising to supply the messengers with presents to him. Tliat arrangements might be made for their immediate departure, some one or other of us would have started at once with the messengers, had horses been obtainable, and if our appearance in the intermediate towns would not liave caused delay, instead of hastening the matter; for native messengers can go without much notice, and can inake a harder push than any of us can do. After breakfast, Amishi, otherwise called Ojogo, which is his public title, came on board, and was shown over the ship and into the saloon, at which he was struck with great wonder; about noon, he returned on shore to despatch the inessengers, who were waiting to go to Keana. After the bustle of sending the messengers away was over, I collected some words in the Doma language from Onuse, the chief's sister; and in return for her services she received one of the glass saucers, which were kindly sent me by Larly Buxton, with which she thought she was amply remunerated.

August 25: There is a tribe on the south bank called Mitshi. They have been represented all along 
as a wild people and wicked archers, and are called Kaferi, even by their heathen neighbours. They came once to Ojogo to sell provisions, but the chief would not allow them to visit him, because they are so much addicted to theft. Early this morning a messenger was sent to Ojogo, to inform him of our intention to visit the Mitshis, and to purchase from them yams and a bullock, as we have been told they have plenty ; - to-day being the marketday between them and the people here. The chief appointed Onuse, his sister, to go and transact the business for us; but when she came on board and found that we had made ready to go, she was afraid, and returned immediately on shore in her own canoe, paddled by females as well as males-for both are equally good sailors. Thinking she would follow us, we started for the Mitshi market, about one mile distant below Ojogo, several Ojogo canoes having already gone before us. On our approach, we heard a great noise and clamour in the market, which is held in canoes on the water-side, and when we came near, all the Ojogo canoes had dispersed in different directions, and everything was in great confusion: some of the women were crying, for the Mitshis had plundered their property, and a strong party had armed themselves with bows and poisoned arrows to oppose our landing. We were but a few yards from them, but could not speak directly with them; besides which, there was such uproar and excitement, that it was impossible to gain their attention. They at times beckoned to us in defiance to land, and armed people were stationed along the bank to oppose our doing so. 
There was not a single weapon in our boat. Dr. Baikie held out some handkerchiefs as an inducement, but the rery sight of them seemed to enrage them. At last, an old grey-bearded man, who seemed to be the chief, with great passion and significant motion of both hands wished us away. As there was no alternative, we returned to the ship, and then went to inform the Ojogo of the conduct of the Mitshis. He had just ordered a canoe, at the report of his sister, to call us back. He said, if the Mitshis, over whom he had no control, should do any mischief to our person or property, the blame would be laid to him. Then we wore told that the Mitshis were camnibals, and that they devour the bodies of their enemies killed in war. But I am inclined to believe that this act of savageness is only practised in time of war, to terrify their enemies, and is not an habitual thing. When the Ijebus invaded Ableokuta some years ago, and were defeated, some bodies of the Ijebu slain, were cut in pieces by the Egbas, and boiled in large pots, that the Ijebus might have the greater dread of the Egbas. Ikumi, the chief of Ijaye, performed a like barbarons act when one of his wives was put to death, either for revenge, or to terrify others from committing themselves in like manner. Before we leave the river, we may learn the certainty of the Mitslis being practically cannibals, or otherwise.

It appears from the information we could collect, that the Mitshis were originally slaves of the Filatas and other tribes in the IIaussa country, and that they made their escape from their masters, and settled 
on the south side of the river, where they have been subsequently joined by a great number of runaway slaves; and have thus become formidable to their neighbours. In this way they maintain their independence, and are always suspicious of strangers going among them. They look wild but timid; carrying always their poisoned arrows about them, which they are ready to discharge upon the least provocation. Their villages, which are independent of each other, spread over a great part of the south side of the Tshadda towards the Akpoto country. They have a language of their own, and seem to acknowledge no superior above the headman of each village. These villagers sometimes fall out among themselves, or village against village, and shoot one another with poisoned arrows. The fact of their possessing a large number of cattle seems to favour the report of their having been at one time connected with the Filatas, as slaves, whose cattle they probably used to tend; and since they have gained their liberty, they pursue the same occupation for their own advantage. Their being prohibited from visiting the ship may be the cause of provocation, which they retaliated this morning in the market upon the Ojogo traders.

From Idda to the Confluence, all the land on the left side of the river, and from the Confluence to this place, is called Akpoto land, and bears the same name at Igara. The Igbiras, Bassas, Agatus, (a tribe of Doma) and also the Mitshis, who are found in the immediate vicinity of the south side of the Tshadda have all come from the north 
side, either as refugees or settlers; and are not the original proprietors of that part of the country, as they themselves confess. Even the Atta of Igara himself appears to be a settler or colonist in Akpoto land, as may be collected from the following tradition among the Igaras:-

As I was comparing Igara words with Yoruba, I asked Mahamma, Ama-Abokko's messenger, whether he could not give me some account of the similarity between some Igara words and phrases and those of the Yoruba-for the affinity appeared to be greater than between any other languages hereabouts. Upon this he related the following tradition:-In old time, the king of Yoruba made a journey to Rabba, when he desired the Atta to look out for a suitable locality for his future settlement. The Atta accordingly took a canoe and dropped down the river till he came to Idda, which was the original name of the town. There he met the inhabitants who were called Akpoto, and their headman Igara, from whom he begged for a place to settle in, which was granted. Atta returned, and reported his success to the king of Yoruba, who asked the Atta, if he thought he would be secure and nobody could trouble him. The Atta answered, that he should be secure. Ilence, the Atta separated and formed a district for himself; and being more influential than the Akpotos, they gave him the precedence. In course of time the language of the settlers gradually disappeared before that of the Akpotos; or rather the settlers appear to have adopted the latter as a medium of communication between them, and 
incorporated it with their own. The true meaning of Atta, is father or patriarch, but his right title as king is Onu, which is the same as Olu of Yoruba, and means king, or governor of a province.

August 26. Nothing of importance, occurred during the day; the little wood the people had was purchased, and the Krumen were sent to cut more in the bush. The wants of this people are so few, that they are content to sit down the whole day smoking their pipes, instead of going to cut wood to sell, although they are very desirous of getting many things by begging.

August 27 : Sunday. Had service at half-past ten as usual, and read the third part of the nineteenth Homily on Prayer. Having been informed that the people were running away from the village of Ojogo, we went on shore after service to ascertain the cause and quiet their fears. During two previous nights, Dr. Baikie and Mr. May had been on shore to take lunar observations, and of course had lights with them. The bull's-eye lamp seems to lave made them afraid. The chief was previously apprchensive of something when he saw $\mathrm{Mr}^{\mathrm{r}}$, May measuring the beach, and thought that he did this because the white men had it in mind to take his coumtry from him. When we got on shore, we desired an interview with him. His heart was throbbing with fear; but I tried to explain to him, how from ignorance of the depth of the river, our ship was grounded very near his village, whicre we rcmained a part of two days; that Mr. May's measuring the beach was to ascertain the breadth of the 
river, and how much it has risen since we have been here: that their looking at the moon and stars in the night, was to ascertain how far we were from our country: that he himself must have taken notice that the moon does not remain stationary, but rises higher every day: so by looking at either the moon and stars, we also know how far we are from home: that God has commanded us to do good to all men, and never to do evil, for if we do them harm, God will not be pleased with us. With this explanation both he and his people appeared satisfied. I asked him, if there were any thing of which he wanted further explanation, as we were ready to give it; he replied, that he had nothing more to ask, but for some red velvet, a stool, and a bason; which we promised to consider when our friends should arrive from Keana. We asked permission to walk a little about the village, which he granted; but in every part of the village, we met bows bent and poisoned arrows ready for action. In one house, we met with Akpama, the Mitshi market-master, who wished us away on Friday; he tried to keep himself out of sight, but we shook hands with him, and asked the reason why he refused our visit to his town, seeing we were walking as friends in the town of Ojogo. He laid the blame upon his unruly young men. We then invited him to the ship on Monday, to be accompanied by Onuse, the chief's sister, and Osaba, our Keana informant. He promised to come, but wished to go home first and give his boys some beer, that they might restore the goods they had taken away from the people of 
Ojogo; -then, he said, we might send one person, with the king's sister, next market, but no white man was to come till the market after next. When we returned on board, two chiefs, higher up the river, Mahamina of Kondoko, and Jefulla of Akpa, sent messengers to enquire who we were, for they were afraid, and to see the ship, which they did, and returned to their chiefs with satisfactory answers.

August 29: Akpama, the Mitshi market-master, did not fulfil the promise he gave yesterday, to come on board according to our invitation; but Mr. May quietly landed, and went to the Mitshi village, where he met the Ojogo's sister and Akpama, who received him kindly, and he brought them both in his boat to the ship. Akpama was very reserved, and felt himself powerless on board the "Pleiad;" his weapons were left in the boat, with his dirty and ragged shirt, and he had but a piece of cloth around his waist. He was kindly spoken to through the Haussa and Doma languages, the latter of which he understood; and two pieces of waistcloth were soon passed around his loins, with which he was not a little pleased. Allusion to lis wishing us away was a painful subject to him. He said, it was a by-gone matter which he did not wish to be repeated; and promised to tell all his people of us, and to bring the chief of Wantele on board to-morrow. But he evidently did not feel at home in the ship, and in about a quarter of an hour, he left it with the chief"s sister, I hope in better spirits. If feelings of confidence and friendship are left to arise gradually in the minds of the people, we shall soon come to a 
mutual understanding, but when there appears to be an impatient desire to visit distrustful natives, such as the Mitshis, suspicion and distrust are awakened on their part, and are not afterwards easily removed. August 30-31: Nothing of importance occurred. The people continued to collect woorl, and we were all in expectation of the return of Zuri, our messenger, from Keana, or to hear from him; he had given us hopes of his return in six or eight days, and it was now the ninth since he left. The rising of the river is one cause for desiring his return with some anxiety, lest we should lose the most favourable season for going as high as possible before the river hegins to fall. Our expectation of the arrival of the travellers is also another matter of great importance, and one which cannot be easily laid aside.

September 1: Many enquiries have been made after Zuri. Sometimes it is reported that he has been seen at Keana, but lias not yet had an interview with the king; at other times, he is said to have seen the king, but received no answer from him; but not a word has reaclied us of his seeing any white men at Keana. Alilieli was sent to one of the men who were reported to lave seen Zuri, but he was told that the person had returned last night. All this led us to suspect there could be no truth in the information given us of the travellers. Zuri had left Orobo, one of lis slaves on board, who spoke the IIaussa and Doma languages, as well as Igbira, and his little son, Musa, continued under our care. When Orobo came on board, I questioned him closely respecting the intelligence about his 
master, and finding he eould not eontinue his lies any longer, he said, it was the oraeles whieh had reported all that we had been told about his master. That this was a mortifying business to us I need not say. We went to the Ojogo, to express our disappointment, and to request him to send anotler messenger, saying one of us would go with him to Keana, to enquire after our friends. I proposed to go on Monday, if Zuri did not arrive by Sunday; but Dr. Baikie not wishing to lose any more time offered to start on Saturday, and with this understanding we left the Ojogo. On our way back we saw Osaba, who we understood had seen the white men at Keana, only eight days before our arrival at Ojogo. I elosely eross-questioned him, when he affirmed that he had seen them five days before he left Keana, exehanging goods with the king to the amount of twenty slaves, but that it was two montlis sinee he had left Keana before our arrival. This statement threw quite a new light upon the subjeet. The mistake of eight days must have been made by the interpreter in the multitude of questions whieh succeeded one another; and we eoncluded they eould not have remained upwards of two months in Keana without the news of it being more extensively spread; moreover, had they been there still, immediately on Zuri's arrival at Keana, they would have written to acknowledge the reeeipt of Dr. Baikie's letter to Dr. Barth, by a special messenger, if they eould not have left immediately. The idea of going to Keana was, therefore, given up, but two days were allowed for the return 
of Zuri, and to eomplete our supply of wood; Monday being fixed for our departure.

September 2: During our stay here, I have managed to fill up the words selected for translation into the Doma or Arago language, with a few additional sentenees. My teachers were so unsteady, not being aeeustomed to sit an hour together at sueh an employment, that $\mathbf{I}$ could do but little at a time, so as not to wear out their patienee, and risk their giving me wrong words. The hopes held out to them of a little remuneration had eonsiderable influenee upon them. I was very anxious to get a few Mitshi words; but none of that people eould be prevailed on to eome near us. Akpama, the market headman, did not fulfil lis promise to bring the ehief of Wantele on board. Aliheli was sent with Ojogo's sister, with some eloth to buy provisions and a bulloek, of which we heard they possessed plenty, but he eould get nothing. When he was bartering for a few yams, some handkerehiefs he had to buy them with, were sto!en from lim, and it was only owing to the kindness Akpama had reecived from the ship that they were restored. Aliheli said they were about him with their lows and arrows, as if they were going to war; and, except $\Lambda$ kpama, not one of them ever eame near our ship. Several strangers from the interior, and from the villages up the river, visited the ship and sold their little goods. Among them was $\Lambda$ saba, a man from Rogan-Koto, one of whose legs was bitten off by a croeodile, but the wound has sinee been healed, and the poor man hobbled from plaee to place with the help of a staff, 
about four feet long. As soon as he was seen by Drs. Hutchinson and Baikie, they began to think whether something could not be done to assist the poor man; and Mr. Guthrie, the head engineer, contrived, and in a few hours completed a wooden leg. Asaba had returned to his tnwn, as Ojogo informed us, to get something for presents to the gentlemen who were making a foot for him; and on his return, the wooden leg was put on by Mr. Guthrie in the presence of many visitors, who were not a little amused at the contrivance of the white men. Our stay at Ojogo had its many advantages. It has become known, far higher up the river, who we are, and what are our objects, so that the minds of the people are more prepared for the arrival of the steamer.

September 3: Sunday. I held Divine Service at half-past ten, and preached from St. John xx. 29. In the afternoon we went on shore to take leave of the Ojogo, and to deliver him a letter for Dr. Barth, in case of his arrival in our absence. The chief was also presented with a red serge cloak, with which he was much pleased. Orobo, Zuri's man, who understood the Djuku, or Korrofa language as well as his master, hesitated to go with us, but after a little persuasion he consented to do so; but said he would not corne on board till to-morrow morning. Further light was thrown upon the character of Zuri by Ojogo, who informed us that Zuri would not be safe if he werc to go to Rogan-Koto, in Doma, which was his mother's town, his father belonging to Abitsh, ligher up in Kororofa. Both these towns 
belong to Panda, their present inhabitants being permitted to occupy them for the convenience of trade. Zuri appeared to have committed himself at Rogan-Koto, and he was declared an outlaw, whom any one who met him might kill, so that he fled for safety down the river. We told the chief that we knew nothing of Zuri's matter with his people, but he was employed by us, and under our protection, and as long as he continued in our service nobody should touch him. It is very difficult to know with what characters one has to do. I had many times suspected that Zuri, while on board the steamer, was assuming an authority to which he lad no right, over those who came to trade at Akpoko; all those who sold ivory had to pay him some cowries, as if on commission. On one occasion, a canoe paddled after us a considerable way, and passed us at night, not seeing us till the next morning, as we anchored in the open river and they went close to the bush. The hard bargain they made for their ivory, constantly going away, and coming back to see what they could get more, and their going away at last without selling it, led me very much to suspect that Zuri had a hand in the affair; but I may be wrong.

The chief town of this part of Doma is Keana, whose ruling king is $\Lambda$ daso, said to be an Haussa by birth, who pays an annual tribute of one hundred slaves to the sultan of Sokoto, through Bautshi. All the small towns dependent on Keana have to pay their share of tribute to Adaso. It appears from the statement of the people, that the inhabitants at 


\section{A CANOE DETACHED TO THE CONFLUENCE.}

Keana sally out from time to time, and catch the villagers as slaves, either in default of paying their share of tribute, or for some other alleged offence. The people of Ojogo had to quit their old town, Ajamo, and take refuge on the island in which they are now scattered in detached villages, which all go by the name of Ojogo, their chief. Such tyranny may account for the hesitation, as to sending a messenger to Ojogo without some fish to conciliate the king's favour.

September 4: Got under weigh about seven A.M., on our exploration of the Tshadda and enquiry after Dr. Barth. The first village we came to, after leaving Ojogo, was Ajamo, where a canoe paddled towards us, to say they had received a message from Zuri last night, who said he would be back in three days' time, and requested us to wait for him, but not a word was said respecting the white men. I, therefore, considered the message to be a mere fabrication, especially as Orobo had refused to go up with us, and had enticed Musa, Zuri's son, to remain on shore with him. After breakfast we parted company with one of the canoes which Mr. Crawford and the second engineer were taking down to the Confluence of the Tshadda and Kowara, with cowries and goods for the convenience of trade: we parted with three hearty cheers. After passing several small villages, the first and second of which are named Kondoko and Amowo, on the right side of the river, we came to Rogan-Koto, situated on the slope of a rising ground facing the river, and walled on the back part. The 
Haussa call it Rogan-Koto, but the people themselves call it Ajewon Igbira. We anchored here for an hour, and went on shore on a visit to Sada, the chief. The inhabitants of this place are Igbira, and belong to Panda (Funda). They were permitted to settle here in Doma for the convenience of trade. Thus, they pay tribute to Panda, their lawful king, and a kind of land-tax to the king of Keana, for permission to settle in his territory. Here we met Asaba, the one-legged man, who was very glad of the leg Mr. Guthrie had made for him, and appears to be quite another man since he put away his long staff. He moved about the deck with much facility, and could not express enough in words his gratitude to his benefactor. One of his wives brought a calabash full of clean rice as a present. The town of Rogan-Koto has not been left unmolested. Last year it was attacked by the Berebere, of Lafia, and a great many of the people were carried away as slaves. They liave just returned to rebuild their ruined houses, very few of which remain. 'T'o those who laad felt the distresses of war, the sound of peace fell upon their ears, as refreshing rain upon a thirsty land. They were kind, and wished us many blessings from God upon the undertaking of the white men to restore peace to mankind. They lad not heard any news respecting any white travellers. After leaving this place, we passed the villages of Kondo and Akpa on the left side; and about four P.M., the town "of Abitshi (Zuri's town), but we did not anchor. It is a small but thickly populated place, and walled around. Like Rogan-Koto, it belongs to 
Panda, and pays tribute to him and Wukari, in whose territory the town is situated. The Wukari territory seems to commence about Kondoko and Akpa; but in consequence of the destruction of Panda, it is likely these places will fall into other lands. From Ojogo to Abitshi, the land rises and is hilly at times on the right bank. The river is very easy of navigation, owing to the rise of the water and absence of numerous islands. Indeed, we have not made such an easy progress since we left Aboh. The Mitshi country extends on to Wukari, at which place we expect to hear more of this singular people.

September 5: Started early this morning from our anchorage, which was nearly abreast Mount Ethiope. The scenery is very picturesque, fresh mountains continually burst into view. There is plenty of water, and the navigation is easy. We passed several small farms and fishing villages, but as it was thought of more importance to push forward to Wukari, we did not stay to ask the names of the villages, though we had several of them given to us at Rogan-Koto. About two P.M., we came very close to a group of huts on the left bank, where it appeared they were making pottery, and dropping our anchor for a short time, we called a canoe alongside. The men told us that the name of the town to which they belonged, is Anyishi, a little way a-head of us on the left side of the river; and that they had sent to inform the chief that a ship was coming. The canoe-men hastened back, shouting, "Sariki n Wukari, Sariki n Wukari! (King of Wukari, 
King of Wukari!) I judged from this exclamation, either that the king of Wukari was there, or that this place must be of some importance belonging to him. We weighed, and in a short time came in sight of the town of Anyishi, situated on a hill on the west side of Mount Herbert; but we did not stop, reserving our visit to thesc places till our return. The face of the country we passed to-day, was nearly like that of the group of mountains between Idda and the Confluence of the Tshadda and Kowara, but the hills are more scattered, and present a beautiful appearance. At times, the river flows at the foot of mountains rising immediately from the water's-edge; for instance, Mount Herbert on the left, and Mount Adams a little before on the right. The banks thus present a very plcasing contrast to the low lands we have passed through. From Ojogo to Anyishi we met more frequently witl villages near the river, and the people were less timid. This, no doubt, is owing to their having heard of the white men's ship anchoring off Ojogo for some days. They always showed a disposition to come off, if the ship would but wait for them. The "Pleiad" was well adapted for the navigation of the river, and even when she went but half-speed, neither her own boat, nor the canocs of the natives, though well manned, could keep up with her in stemming the current, which runs from one and a-half to three knots per hour. We anchored for the night, but remote froin any human habitation.

September 6: Started very early this morning. 
The state of the river continued very favourable, the breadth not much diminished and good depth of water. The face of the country is very flat two or three miles inland on both sides, and there was no appearance of town or village, nor even of a fishing hut till about half-past one, P.M., when a fishing hut was seen on the left bank, but nobody was in it. At four o'clock we spied a group of houses at a great distance before us. This was something delightful, and about five P.M., we anchored off the villages of Gandiko, whose chief was Ama, and Gankera, whose chief was Garike. Before the ship came to an anchor, intelligence had reached the chiefs of the villages, and all hands were up in arms. Their weapons were bows and poisoned arrows, and long spears, and some men carried three or four of the latter poisoned also. Our boat was ready for us, and we pulled towards shore in search of the landing-place. There were some plantations of maize and guinea corn along the water's edge, and some of the farmers were near; three women stood very close to the bank with seeming confidenee. We addressed them in Haussa, to which they replied, and asked them for the landing-place, but they gave us no satisfactory reply. A little way higher up, we saw a man on the bank, who drove the women away. We addressed him in Haussa, and he replied: we told him we were from the white man's country, and wanted to see the chief. As soon as he saw the Europeans, he cried out lustily in Haussa: "Bature Anasara maidukia na gode Alla," - "White men, the Nazarenes, men of 
property, I thank God!" many times over. He took the lead through old cultivated grounds, but overgrown with grass and bushes, through which we had to beat our way to the footpath leading to the town. Our leader, either from excitement or intoxication, became louder and louder in his cry, "Bature Anasara maidukia na gode Alla!" We soon came to a iuncture of two paths, where the Galadima, a war chief of the first rank, and next to the chief, with a small party of about twenty-four men, armed with bows and arrows and spears, were stationed, and our leader with his boisterous cry introduced us to them as men of peace and trade; in the meantime, we were lost in the midst of the soldiers, Dr. Baikie was in one direction, Dr. Hutchinson in another, and Mr. May in the midst of the soldiers. We had not a single weapon about us, offensive or defensive; but the confidence with which we went among such an armed party was enough to prevent their doing any mischief. During our whole progress the few instances in which hostility was shown or opposition made to our landing arose out of nothing else but want of mutual understanding. On the present occasion, as soon as we came together, we shook liands with the Galadima, and he led us to the town. The path was full of soldiers coming out to join the Galadima; but seeing him return with us, they all fell back on both sides of the path which brought us to the entrance of the town. The place was fortified with a wooden fence and a ditch around it; and in the midst of the town and under a kind of fig or banian tree planted 
for the sake of its shade, we met the chief, Ama, also armed with a bow and arrows as were about two hundred men with him. We were introduced to him by the Galadima, and after shaking hands, conversed briefly with him respecting our visit to the country. He appeared quite satisfied, and requested us to return to the ship, and wait till to-morrow before entering into particulars of the object of our journey. We returned accordingly with the hope that we might be able to visit Wukari from this place.

What is generally related of the natives of Africa as to their hostility to Europeans is not strictly correct. The truth is, they take alarm, and consequently get ready for the defence of their country, which is divided by wars, marauding and robbery into many independent states, and every district must watch against surprize by its neighbours. It is but natural for such a people, shut out from communication with the civilized world, when they see for the first time such a huge and self-moving body as a steamer, to take alarm, not knowing the object of those who inhabit it, for to their ideas it is a town of itself. There is one thing which enterprising European explorers overlook, I mean the continual fear and insecurity the Natives are in, from the constant treachery of their enemies. This causes them to go. about always armed with their bows and arrows, and at the least alarm they are ready to discharge their deadly weapons. Though travellers fear nothing themselves, yet, they should endeavour to take due precautions to 
allay the fears of those whom they intend to visit, by previous communication, which will soon be circulated in the neighbourhood, and then all will be right. A prudent man will not consider an hour or two wasted to effect this purpose, rather than risk the painful result of misunderstandings which may never be remedied. As far as I know, there is no place in Africa uncontaminated with European slave dealers, which Europeans have visited with the intention of doing good, where such an event has not been hailed as the most auspicious in the annals of the country. Every chief considers himself highly honoured to have white men for his friends. - In the evening, thc chief sent a vessel of beer and some eggs to Dr. Baikie for a present.

September 7 : About ten, A.M., we went on shore to have an intcrview with the chief. After standing about ten minutes in the front hall, which forms the entrance into his inner yard, he came out and seated us on a coarse mat platted of straw or small grass. After the usual salutation, we commeneed stating the object of our visit. But Ama the chief was interrupted; Garike the clief of Gankera was outside, and he ought to have bcen invited in, which Ama did not feel inclined to do. A long discussion ensued betwcen him and his pcoplc, and after a little cessation, Ama wished us to say what we wanted to say, and to give what we had for him, and then, he said, we might go and salute the other chicf outside under the tree. He was answered, that we must leave it to him whether the matter was to be talkcd 
over here in his hall or under the tree, for we were strangers, and he was to give us directions. As we would not proceed, he went out and invited Sariki Garike in. This man looks older than Ama, and neither of them appeared to understand, or at least they would not speak Haussa, the Filani language being their medium of communication, as well as the Djuku, which is the language of Kororofa. Everything said in English was interpreted into Haussa, and the Haussa was again into Filani or Djuka to the chiefs. They had not heard of the Anasara traveller, (Dr. Barth) and were very glad to hear that trade would be established with them. They said, if there was no trade with foreigners, the country would never prosper; that they were weary of making war, to which they were always sent by their masters, that they came to this place to settle and cultivate the land, and that if they had anything else to do, they would not go to war, unless for the defence of their country, or at the command of their superiors. They had heard previously from their men, that we were not slave dealers, hence the turn given to their intercourse with us. As regards our journey to Wukari, after Ama and Garike had conferred together, Ama replied, that they were at war with Wukari, so that we could not go there from this place. He asked whether we did not see the town Anyishi on the hill as we passed up the river, and on our replying in the affirmative, he said, that was the place to ask the way to Wukari. After Dr. Baikie had made them presents from Government, we obtained permission to walk about the 
town; and visited Gankera, the next village, muclı larger than Gandiko, where we saw some Arabian horses in very good eondition, kept purposely for catehing slaves. I saw two females in the town whose only clothing consisted of a few leaves, and who seemed quite unconcerned about their condition. I hope to be able to learn partieulars about this people hereafter. We returned to the ship about two P.M. While the Krumen were wooding, some ivory was brought on board which was purchased. A mallam, a native of Kano, who had come to this place on a visit, told me that Ama had deeeived us as to the road to Wukari; and that had we landed about three miles below, we might have gone there, assuring us that he had lately come from that place on a visit to the king, who gave him the tobe he had on. There was another Haussa man in Gankera, who was very anxious that we should visit Wukari, and offered to place his horses at our service, and to accompany us himself, but as Ama had put difficulties in our way, he could do nothing. The pretended war, which Ama said they had with Wukari, was of ancient date. It appears, at one time, the king of Kororofa being annoyed by the Mitshis, or some restless tribes about him, hired the Filanis to assist him to conquer them. When this was done, the Filanis, according to their usual práctice, settled permanently in that part of the country they hac cncamped in, and annoyed Kororofa itself instead of returning to their own country; hence their war with Wukari, and as they were too powerful to be dislodged by 
the Djuku, and could not conquer Wukari, they became masters of that part of the country, which goes by the name of Zhibù, comprising six towns and villages on the left side of the river, viz. Hunue, Wazhiri, Gandiko, Gankera, Ibi, and Zhibù, the capital, higher up. Three other towns, Mitshi, Fagarike, and Baibai, are mentioned, but they seem to belong to Wukari. They appear, at present, to be at peace with Wukari, though the latter owes them a grudge for encroaching upon his territory. These marauders make yearly incursions into the Mitshi country, and the outskirts of Kororofa, and carry away captives, to sell towards Keana, in Doma, Bautshi, and Kano. The slaves are, undoubtedly, marched across the desert to supply the markets there, and this circumstance will explain the depopulated state of the country from Anyishi to the district of Zhibù-thus a distance of about forty miles, with beautiful ridges of highland rising beyond the magnificent Binue, presents a continued wilderness without inhabitants. In the afternoon the chief, Ama, came on board, and was shown round the ship, which surprised him not a little. The people possess a few miserable canoes made from parts of trees sewn together by ropes. 


\section{CHAP. III.}

INTERVIEW WTTH THE CHIEF OF ZHIBU-PROGRESS TO ZHIRUDEGRADATION OF THE PEOPLE-DIFFICULTX IN PROCURING FUEL-GUROWA-VISIT TO HAMARUWA-FAVOURABLE RECEPTION BX THE KING-DESCRIPTION OF THE TOWN-ITS TRADE-FAILURE OF WOOD FOR FUEL-DETERMINATION TO PENRTRATE THREE DAYS' VOYAge HIGHER IN THE BOATTHE STBAMER COMMENCES HER RETURN-GROUNDS ON A MUD BANK-RETURN OF THE BOAT.

September 8: Started this morning, and about one P.M., anchored off the town of Zhibù. The arrival of the ship at Gandiko had been heard of, so that there was no cause of alarm, and we immediately sent a message to inform the sariki that we would shortly pay him a visit.

The town is about a mile from the river, situated on a rising ground, commanding a fine view of the Binue and the country around, and appears to be of greater extent than Idda in Igara, compact and thickly populated. After about a quarter of an hour's detention in the street, we were invited in by the sariki's messenger, and passing three entrances of conical roofs, at some distance one from the other, we came to a fourth, where the king was sitting, ready to receive us. He told us that his name is Bohari, but he is generally known by the name of Zumbade, and is the head, or king of the Zhibu district. He is by birth 
a Djuku, or Kororofa, as are also Ama, of Gandiko, and Garike, of Gankera; he seems to be about forty years of age, and is rather of a surly countenance. After the usual salutation, Dr. Baikie told him the objects of his visit; namely, to enquire after Dr. Barth, and to propose opening trade with them. No intelligence of Dr. Barth had reached them; of trade they were highly delighted to hear, and requested at once that the ship should proceed no further; but they were told that we must proceed onward to make enquiry after the white man, if possible, at least as far as Hamaruwa. The chief said it would take us eight months to go there, and the river would rise during this month only, and begin to fall the next, and in a little time it would not be deeper than a man's waist, so that our ship being large, would not have water enough for the voyage downwards; besides which, there are many rocks in the river, and he was afraid, if any thing should happen to the ship, it would be attributed to him, for not having given us proper information; that the people ligher up were Kaferis, and would run away when they saw the ship. We soon perceived his motives in all this, but thanked him for the information. Dr. Baikie gave him presents from government, for which he gave in return, a slieep and a calabash of fresh butter, and an Haussa tobe to Dr. Hutchinson. But there was another question, which the most hardened conscience must feel to be disgraceful to humanity. The king called Aliheli, our interpreter, into the inner yard, and showed him a little boy whom he 
had to sell, and asked him whether he would not purchase him. Aliheli told him, that Englishmen were altogether opposed to the slave-trade, and when they came out, he requested that the ship might stay to-morrow, that his people might have the chance of selling ivory-a request which was at once complied with. We then returned to the ship. When the chief was asked if a bullock could be purchased, he said they had plenty, but they were with their masters. He was asked who these masters were, but gave an evasive answer; but we had learnt from the people that they were slaves of the Filanis, and came from Yola and Hamaruwa, which the chief did not wish to confess.

September 9: While the Krumen were engaged cutting wood, the people came on board to trade. Bohari, the clief, rode close to the bank to see the ship, and to observe how his people behaved. With some persuasion he was got on board, but not before he had ordered all the traders to be removed from the ship. $\mathrm{He}$, as all the others had been, was surprised at the size of the ship, and no wonder, for they themselves have but very few canoes, small and old, hollowed in parts out of two different trees, and sewn together with ropes, as one would join an old broken bowl. The slip's boats had to convey the traders to the ship, and land them the whole day. The kinds of grain grown here are maize, or Indian corn, guinea corn, and the straight-headed grain, called gero, and dawuro; rice is grown, but in very small quantity, though thousands of bushels of it might be 
produced yearly on the irrigated banks of this river, which would supply millions of people with wholesome food. In consequence of the men being chiefly occupied in marauding expeditions, the infirm male and female slaves are generally employed in the cultivation of the soil. No yams, plantains, bananas, coco's, oranges, cocoa-nuts, or pine-apples, are to be obtained-these plants not being cultivated. No eatables are hawked about the streets by girls and women, nor are there any places of refreshment, or eating houses under sheds; in short, there is no market in this country like those met with on the west bank of the Niger. They barter one thing for another, corn for beer, and beer for corn, ground-nuts for rice, \&c., but some people took cowries for ivory, to be carried to the Haussa country, where they are current. There is a total absence of palm-trees here, and consequently no palm-oil, and soap is a very scarce article. The people, with very few exceptions, are scantily clothed, ragged and dirty. Clothes are consequently in great request, so that in exchange for fowls, goats, sheep, ducks (of which they possess many), and for mats and corn, they ask cloth. The chief offered to send some persons with us to show us where the rocks were, and his offer was accepted, but they were not ready to come on board till the morning, and were told to be ready at cock-crowing.

September 10: Sunday. Got under weigh at six A.M. The guides were not forthcoming, so that we went without them. About ten A.M., we anchored, and had divine service about a quarter to 
eleven. I preached from Heb. vi. 19. At one o'clock we got under weigh again, and anchored about six P.Mr., having made about sixteen miles above Zhibù. This morning, as the Krumen were set to cut wood for the furnace, I could not but feel for them, as they went very reluctantly to work. It is a reproach to us, who profess to observe the Lord's-day, and teach others to sanctify it, thus to violate it ourselves. Six days hard labour is sufficient for any man or beast, and all ought to rest on the seventh. What good could I do among the Krumen on the Lord's-day, when speaking to them of the Christian Sabbath? No human habitation was visible from the water, and the country continues low and flat; but rising ground, at times, appeared at some distance from the river. A singular-looking isolated sugar-loaf hill was seen on the left side of the river, in the direction of the back, or south side of Zhibù. We anchored among a herd of hippopotami, which were heard grunting about the ship; Dr. Baikie and Mr. May landed in the evening to take observations, but, from the proximity of these animals, were obliged to conclude their operations as speedily as possible.

September 11: Got under weigh about six A.M. The country continued very flat for about three miles on an average, on both sides of the river. About eight A.M., a large forest of cabbage-palm, or palmyra trees was seen on the right side of the river, extending a considerable distance. The river here spreads very much, and shows considerable banks in the bed of the stream. In some parts 
they are partially covered, and when the water falls must form extensive plains of sand. We anchored about six P.M., having made about twenty-five miles. Flocks of wild ducks were sitting on the sand-banks, but as it was getting late none could be killed. A range of high mountains was seen at a distance on the lcft side, named Albemarle Range. No vestige of a habitation appeared all the way.

September 12: Got under weigh as usual. The country began to present an undulating appearance at a little distance on both sides of the river. About noon we passed a feeding stream on the left, the first we have met since leaving the Confluence, and immediately after, the Tshadda became extremely narrow, being hemmed in by rising ground, espccially on the right side, for about a quarter of a mile. The depth was not less than five fathoms, and the whole volume of the Binue having to pass this narrow gorge, the current became so rapid, that it was difficult for the "Pleiad," with the aid of two small sails to stem it. We began to apprehend some difficulty of navigation; but to our no small joy, after rounding Lynslager Point, we found the Tshadda spread its noble stream over as extensive a bod as before. However, being short of fuel, we dropped anchor about two P.M., to cut wood, but unfortunately, the trees liercabouts are not of good quality, and only a little was cut to eke out tho scanty stock of dry wood on board. A party who went slooting on shore, reported that they had seen traces of human footsteps on the beach. 
September 13: We remained still at anchor. All hands employed in splitting the dry wood for use. A canoe with three men was seen this morning at some distance from us, but they immediately disappeared in the bush, and would not come near. We wished much to receive sone information from them as to the distance we were from any habitable village, and from the port of Bomanda, which appears to lead to the town of Hamaruwa.

September 14: Weighed about 6 A.M., and about half-past eight we had heavy rains with a high wind, and were obliged to anchor until the storm was over. We weighed, and finding a large dry tree on the left bank, anchored near to it, about two, P.M. The men werc immediately set to work, and some quantity was cut before dark. There is still no appearance of town or village, nor of fishing luts or traps, nor even of cultivation of any kind.

September 15: Continued wooding. About nine, A.r., three canoes were observed pulling downwards on the right side of the river. They saw us, and stopped to land their property on the opposite side, leaving one canoe there to take care of it while the others paddled across towards us. Every precaution was used to prevent their being frightened away. The interpreters accosted them in Haussa, to which they replied, and being invited on board, five of them came on deck. 'They were Filani traders in slaves from Bomanda, near the town of Hamaruwa. They left Bomanda on Tuesday, and made short journeys, first to Tshomo, 
whence they went to Zhiru on Wednesday, and then to Nak, where they slept last night, and started this morning from Nak. They informed us that we were in the Hamaruwa territory, and that one day would bring us to Tshomo, the port of Bomanda. They gave us the names of some villages we should meet with on our way, viz., Nak and Zhiru on the left side, and Tshomo on the right; and said, that the feeding stream we passed on Tuesday is Akam river, with a village called Wunubo on the bank of it; that there are scattered farm villages in the interior, where the slaves cultivate corn for their masters; that the inhabitants of the Zhibù district are Hamaruwa's slaves, and that all this country is inhabited by Djuku or Kororofa, the same with Akpa or Apa, which is the language of Wukari, the capital of Kororofa, now subject to the Filanis. They asked whether we wanted to purchase slaves, to which we answered in the negative. One of them said he had ivory at home, and he would be back in two days, when he hoped to meet us and sell it. They defined as well as they could the boundaries of Kororofa, Hamaruwa, Adamawa and Bautshi; and said that the mountains visible before us, were Fumbina mountains, and that we should be eight days going to the Confluence of the Binue and Faro, pointing to the direction of the rise of the latter on the left side of the former. They added, however, that the people of Adamawa were Kaferis, and that they were apprehensive they would fight us. All this information was very 
satisfactory, and we still entertained the hope of being able to reach the Confluence of the Binue and Faro. We gave them a few presents, and showed them over the ship, which pleased and surprised them much. They could give us no intelligenee of Dr. Barth, nor did it appear that they had heard of his visit to Yola. By six P.M., all the wood was got on board, but the ship and eanoe were kept alongside the bank to enable Mr. May to take a star's altitude. There were some goats and sheep in the eanoe where they were always kept. It would seem that the scent of these ereatures attraeted some wild beast of prey, supposed to be a leopard, whieh approaehed very elose to the ship. A little before seven, as Mr. May and Dr. Baikie were on shore taking the observation, a growling was heard among the long grass elose by, and some of the sheep and goats would have been earried away had not the danger been known in time; or, what is worse, the gentlemen miglit have been attacked when engaged with their instruments. Several loaded fowling pieces were fired off, which no doubt frightened the beast away; but the period for the observation was unfortunately missed.

September 16: Got under weigh about 6 А.M. The river keeps it breadth, but there is plenty of water, from three to four fathoms. We missed the ehannel, and the slip grounded three times, but she was got off by backing the engine with little effort on the part of the men. $\Lambda$ new range of lills showed itself at a great distance on the left 
side of the river, eonsisting of many lofty conical mountains. It lay behind a long ridge of high lands, rumning to a considerable distance, almost parallel with the river, which presented a very picturesque appearance. The tops of some of these mountains are eovered with luxuriant woods and jungles, and others are quite bare and rocky. Though all these are pleasant to the eye, yet there exists no trace of any part of them being inhabited.

About eleven A.M., we passed a small group of huts on an island on the left side, which we supposed to be the village Nak, of which we were told by our informants yesterday. Our progress was very slow to-day, botll from touching so rnany times when we missed the channel, and for want of proper fuel to keep up regular steam; in consequence of which we were obliged to anchor many times to get it up. We eame to anchor about six, P.M., liaving made about twelve or eighteen miles against a very strong current with a short supply of steam.

September 17: Sunday. Dr. Baikie proposed to have service earlier, about nime A.M., instead of half-past ten, and to make half a day's sail, and meanwliile the Krumen were set to split wood for fucl. Aceordingly, I performed serviee at nine A.M., and preached from Dan. iv. 39. There not being a sufficient supply of wood, we could not start, but the Krumen were kept at work splitting till the evening.

September 18: Weighed about six A.M. At nine we saw the luge carcase of an hippopotamus floating 
down the river, and about four P.M., we anchored off Zhiru. The natives, who stood on the bank, within hearing, and armed with spears, were at first timid; but a little conversation with them in Haussa, and a request to be supplied with provisions soon inspired confidence. We landed on the bank, and shook hands with them, had a little conversation, and made some hasty enquiries. They were sent to inform their chief that we were coming to visit him shortly; and a little while after, the messengers returned to invite us to the town. On our way to the chief, under the guidance of one of the men, another motioned us back, and introduced us to a Filani mallam, whose name was Imoru, stationed here by Mohamma, the king of ITamaruwa, as a kind of deputy or consul to watch the interest of his king, because the inhabitants rob and plunder travellers on their way to and from Sokot), Kano, Katshina, and Bautshi, as they carry on trade through Hamaruwa to Adamawa. Dr. Baikie being, for the first time, too ill to go on shore to communicate with the chief, deputed $\mathrm{Mr}$. May to act for him. Made our usual enquiry after Dr. Barth, but no intelligence of him was received. Inoru confirmed the statement that the people of Zhibù were their slaves. He was ready to send a messenger to inform the king of Hamaruwa of our arrival. The messenger, we were told, would arrive that evening and return to-morrow morning. Imoru could not give us any information of places beyond Hanaruwa, other than the name of a town he called Batshama, whose inhabitants he termed 
Kaferis, and said they were a bad people. He asserted that it would take us twenty days canoevoyage to reach the Confluence of the Binue and Faro, and that it is ten day's journey to Adamawa. From this I understood Adamawa to be the name given by them to a principal town in that extensive country. Hamaruwa and Yola are entirely independent of one another, each holding direct communication with the Sultan of Sokoto. The present we brought for the chief was given to Imoru; but I suspected there was another, but oppressed chief, in the town, to whom I imagined we were being led when called back; so I asked Imoru to direct us to whom we should pay our respect next to himself. He then told his servant to accompany us in the boat to the other end of the village, where we landed, and were conducted to Fadon, the original chief of the place, and the true patriarch of his people, but whom we met greatly dejected, evidently oppressed by the followers of the false prophet. We asked after his welfare, and spoke kindly with him, but as he did not understand Haussa, the servant of Imoru interpreted for him in Djuku, which is the language of the inhabitants. A promise was made to him that he should receive presents similar to those given to Imoru, as we were not aware there were two ruling chiefs in the town, and he was instructed to send some trustworthy person with us to the ship to receive them.

Since leaving Fernando Po, I have not met with any people so much degraded as these. It is true, 
that we have all along found the natives, except the children, more or less clothed, but here I was surprised to find elderly women with only a few leaves suspended from a string round their waists, with pipes in their mouths, and exhibiting the greatest unconcern. This is the same race of people I saw at Gandiko, and at first, I suspected they were Filani slaves, but upon enquiry, I was told they were free persons. It appears that these aged people would not change even the most uncivilized of their habits, though after their country had fallen into the hands of the Filanis, the men and other women adopted a better mode of clothing.

September 19: There was nothing to be procured here, neither sheep, goats, fowls, nor even wood; we, therefore, returned to the ship. Dr. Baikie requested the mallam to inform Mohamma, the king of Hamaruwa, that we would call on him on our way back in a few days. The mallam came to see the ship, and we managed to get some more information from him, and then got under weigh, in hopes of being able to find some trees suitable for fuel at Tshomo, the next village, where we were told we should get plenty. The steam could hardly be kcpt up, and we were, consequently, obliged to drop anchor several times, the current running upwards of three knots against us; but about four o'clock we were pushed forward by a tornado from the eastward. The river takes $a$ northerly direction about this place, and we saw two villages at the back of the swamp, and the 
town of Hamaruwa was visible from the masthead, on a hill at the foot of the chain of Muri mountains. At six, we came to an anchor, in hopes of getting some fuel, the quantity on board being scarcely sufficient to get up steam. We had made about eleven miles from Zhiru.

September 20: The boat was early sent on shore to see what wood could be obtained, but nothing was found suitable to our purpose, the trees being all green and sappy, and standing in swamps, where the men could not have maintained their footing, had the trees been such as we wanted. Another boat was sent higher up, to see if there was a village near, but it returned without finding one. As there was no alternative, a look out was kept to capture the trees floating down the stream; and two were secured before breakfast, the chase affording us no little amusement. About ten another was chased and captured, so large that it pulled the boat a considerable way down the river, but it was sccured, and greatly added to our little stock to enable us to get to Tshomo. In the meantime, Imoru, the mallam of Zhiru, came on board with the leg of a buffalo, killed last night for a present to Dr. Baikie. The doctor would have bought the head, but the superstition of the people was so strong against selling it, that they begged him not to be vexed at their denying him that request, nor conld they be persuaded to sell the skulls of hippopotami, which were piled up before the fetish, in the town of Zhiru. I asked the mallam whether the people are willing to embrace Mohamedan- 
ism? he said they were not. Imoru very earnestly told Aliheli to ask me if I would pray for his wives, as they had no children. I at once called for my Bible, and read Psalm cxxvii., which I tried to explain to him, and showed him my arms and neck, to prove that we never used charms for ally purpose; telling him that we resign all our affairs to the hand of God, who knows better what is good for us. He was quite satisfied with my explanation, though he felt disappointed of his hopes. Imoru told us, that we should meet the king's messenger near 'Tshomo.

September 21: Having succeeded in securing enough floating trees and drift wood to get up steam, we started this morning, and about noon several villages were seen at some distance on both sides of the river, which were Bomanda. on the right, and Little Tshomo on the left side of the river: all situated on the plain, but sufficiently elcvated to insure their not being flooded at the rising of the Binue, which is very considerable. Opposite Little Tshomo, we saw five men on a tree in the swamp, who had been stationed there to invite us to anchor; the canoe which brought them there had returned to inform the chief of our approach. $A$ little further on we saw a large number of people on the roofs of their houses to look at the steamer, while others waited at the landing-place to invite us to anchor, but as there was no wood to be obtained there, and we were told that at Great Tshomo we should get abundance, we did not wait. In a sliort time se- 
veral canoes began making towards us, and as we had to anchor every now and then to get up the steam, they soon came up to us, and after a little persuasion came alongside. The principal persons were the brother of the late king of $\mathrm{Ha}$ maruwa, a son of the late king, and Ibrahim, entitled, Sariki n Haussa, an intelligent Filani of Kano, who was master of the Haussa language, and the king's messenger. He appears to be the chief trader of the king of Hamaruwa. In a little time they were at home in the ship, and became familiar friends. But a laughable scene of fear and confusion soon took place; the steam was up, and the vessel weighed; no sooner had the fan began to play, than the canoe-men, one after the other leaped overboard, and swam to their canoes in great consternation; it was with much persuasion that I kept the king's brother from following their example. The engine was stopped, and those who wished it, left the ship. Those who felt more confidence remained with Ibrahim and the king's brother till the afternoon, when we were short of fuel again, and were obliged to anchor about two miles below Tshomo. The report of the ship had reached the king the evening we anchored off Zhiru, and Ibrahim was despatched by him the next morning to wait our arrival off Tshomo, and to ascertain who we were, and what our objects, as well as to express his wish to see two messengers from the king of the ship to substantiate the report which had reached him, respecting the Anasara's ship on his waters, Ibralim said, moreover, 
that the king would accompany the messengers to see the ship himself. But as we had not got to Tshomo, and there was no appearance of wood on either side of the river, Dr. Baikie could give no positive answer, but sent the messenger on shore to wait till to-morrow.

September 22: The heavy pieces of wood which remained on board were split, and some empty casks, not much wanted, were broken up to get up steam. About breakfast, Ibrahim and the king's eldest son were again on board, and repeated their request for two messengers to accompany him to Ilamaruwa, according to the wishes of the king. As I am not yct master of the Haussa language, the only thing we could do, was to take Aliheli as interpreter, and Mr. Richards and myself offered to go with him to the king. This met the Doctor's wishes, and about ten A.M., we left the ship in the gig, with Ibrahim, with instructions to send the boat back as soon as we landed, which we supposed would be immediately at the village of Tshomo. A mile and a half from thic ship brought us to Gurowa, called the king's farm, on the riglit bank, built on a small elevation beyond the rising of the water. Ibrahim landed here, and brought something with him into the boat; the Filani chief also, Shiroma Bukari, came on board to salute us, and returned on shore. This village is inhabited by the king's slaves to cultivate corn, and kill hippopotami, buffaloes, \&c., for the use of thcir master. Two miles morc brought us to Tshomo, situated on the same side of the river, on two small 
eminences separated by a small creek, but inhabited chiefly by the original natives, many of the females being as destitute of clothing as those of Zhiru. The mothers were seen carrying children in their arms, or on their backs, with the hands of the infants beneath their arms, by which they were held fast. Here again I was struck with woncler, at the low and degraded state of the human race, when removed from all civilization. I asked Ibrahim, why they had no clothes, and he said, it was their fashion. I asked for the chief, and he pointed out an elderly grey-bearded man, standing under a tree near the water-side, with only a small piece of dirty cloth round his waist-this was the Sariki of Tshomo. Before Ibrahim left the town, he managed to squeeze a large calabash full of Indian corm, and some quantity of stinking hippopotanus flesh from them, because they did not provide for him when he passed the night in that village. I had always considered the natives of Fernando Po to be the most uncivilized I have seen, but this people is more degraded than even the Bubis of that Island.

The crcek which divides Tshomo had not enough water for our boat, so we had to pull through the flooded corn fields to get into the main creek, but as the whole was overgrown with grass and corn stocks, Ibrahim was obliged to get one of the canoe-men to take the lead. Our Krumen did not like either the appearance of our guide, or the passage he was learling us through. As a fisher and hunter of hippopotami, he had with him five $01^{\circ}$ 
six harpoons or spears, and pulled through the grass with his narrow canoe like a snake, while the grass was so thick that we could not see him ahead of us, nor perceive the track of his canoe. However, we followed in his direction, till we met him under a tree where he waited for us. We had here to stoop beneath the low branches, but a short distance brought us to the main creek. The bank being only partially covered witlı water, the men jumped out and dragged the boat across, and our pilot then left us to ourselves. I called the attention of Friday, tlie head Kruman, to mark the direction of the tree, that they might not miss the way on their return, but captain Friday and his crew did not seem to relish tle idea of returning alone among this rude and apparently ferocious people. $\mathrm{We}$ followed the creek, thinking we should soon come to the landing-place, but contrary to our expectation, we did not land till one o'clock P.M., four hours after leaving the ship, our progress having been down with the stream since we came into the creek, which runs parallel with the river. From all the enquiries we had made, Hanaruwa did not appear to be more than six or seven miles from the river; and considering the distance we had made down the creek, I thouglit we must have been at least three or four miles nearer than if we had landed immediately on the bank of the main river. It seemed to me that if the Krumen had to return with the boat against the strean, in the circuitous creek, they would not get to the ship before dark; and under 
the impression that an hour or an hour and a lialf at least would bring us to Hamaruwa, and that we might be back by five, and return to the ship together, especially as there was no other conveyance for us except two miserable patched canoes, used to fetch corn from the plantations; I ordered the boat to be pulled up, and leaving it and all belonging to it to the care of the headman of the village of Wuzu, we started for Hamaruwa. An hour's walk brought us in sight of the first farm village, which $I$ at first took to be the capital or its suburbs, but I was mistaken, and was told the town was yet before ns. Another hour brought us to a second farm village, and our way led almost direct west towards the furtliest mountains we had left westward. By the time we had travelled three hours, the Krumen who were as much deceived as ourselves, became very much dissatisfied, and they expressed regret that they had not returned to the ship, instead of going such an unpleasant journey in which they had no interest. Truly it was unpleasant, inasmuch as we were deceived as regards the distance, and the road was by no means enviable to walk in. We had not left Wuzu half an hour before I was obliged to take off my shoes, and roll up the legs of my trousers to my knees, as did Mr. Richards, to wade through the continued splash of water and mud we met with more than one-third the way. I kept pace with Ibrahim in hopes of sighting the town so as to convey the intelligence to my weary companions for their encouragement, but we saw 
nothing up to about four o'eloek, when we eame under a trce whieh was a resting place. I stopped Ibrahim, to wait for the Krumen and Mr. Richards, who werc yet a great way behind, when Ibrahim to cncourage me, said, we had made a little more than half way. While we were waiting, he performed his devotion. I told my servant to climb up the tree, and hail the interpreter, whieh he did for a long while, when Mr. Riehards answered at a distanec, that they were eoming. He was obliged to beg water for the Krumen at one of the villages, for they were lungry, having missed their midday mcal; and they felt it much, as well as the fatigue of a journey for whieh they were unprepared, to an unknown placc among a strange people, who were only known to tliem as slave hunters through the country. Mr. Richards told me tliat he liad liard work to persuade them onward. I eneouragerl them by reminding them that we werc all similarly situated, but felt sorry for them as they might have got baek, and thus avoided all this troublc. It was sunset before we cntered the town of IIamaruwa, and caleulating from the halts we madc, and the grcat diffieulty of walking in water and mud one-third of the way, that we did not travel more than two miles and a half per lour from Wuzu; we imust liave gone twelve miles and a half in a westerly dircetion before reacling the place. When we got half way into the town, Ibrahim slowed us the king's house, into whicl he went, giving his companion directions to lead us to his own, at the 
other end of the town, where we were lodged. It took us about twenty minutes to walk to it; and all our party were glad to rest themselves, humgry and fatigued with so long a journey. About ejght o'clock P.M., the king sent eight bowls of provision for us, enough for thirty persons, we being but eleven in all; but the Krumen, though hungry, did not like the Filani food, called tuo, made from Indian or guinea corn, in substance like hard dumpling, over which sauce was joured, and which is eaten with the fingers.* One of the men would not eat at all, so I gave him some biscuits we had brought for lunch, but had not touched on the way. Ibrahim sent two more bowls of tuo in addition to the king's supply, besides some nice nixture of fura, prepared from Indian or guinea corn, to , be mixed in water for a nice cooling drink, with sometimes a little pepper and honey added to make it more pleasant. The king sent five sheep and lambs, with a kid, six in all, and a large pot of plum honey for our entertainment;

* The following description of the Yoruba method of eating their food is taken from Miss Tucker's Abbeokuta, p. 26, and will illustrate this passage:-The repast "consists of balls of Indian corn, called 'dengè,' served up in a kind of strong sauce made of beef, mutton, fish, or fowl, with various vegetables, and seasoned with salt procured from the Popos, and with Cayenne pepper, which grows in the country. *** When about to partake of the food, a large earthen bowl is placed on the ground, containing the denge and the sauce; and the party sit down round it. The balls of Indian corn are taken out of the bowl, broken and distributed to the different persons, each of whom dips his portion into the sauce as he eats it. There is a good deal of animal food consumed in this way, but it is ncver caten solid." From p. 117 it appcars that the sauce of IIamaruwa is made with cow butter. 
but unfortunately, before the honey was delivered, the pot broke, and the whole was spilled in the yard, to the great grief of all present. Ibrahim came with much sorrow to tell me of this great misfortune, and I must say, I felt the loss myself, because it would have been a very acceptable present to all the ship's company, considering that since the fourth instant we had been out of sugar. Butter and milk had been all consumed long before, and a pot of honey would have been an invaluable substitute. But travellers must take things? as they come, and be content with such things as I they have. The Filanis use no lamps in their houses in the evening, we had therefore to remain outside the house where we were lodged, seated in the dark, as they themselves did, till bed time, when a few sticks were kindled which gave out much smoke and little light, to enable us to ascertain the position of our bed, which was rough enough. Before we turned in, Ibrahim requested me to take care of my sheep and goat in our room, for fear of the wolves with which the country abounds. I told him it was impossible to admit five sheep and a goat into a room alrealy filled with eleven occupants, and he promised to take care of them for us till the morning. Ibrahim's yard was full of visitors going and coming, to whom he was relating the wonderful news of the Anasara's ship made of iron, and moved by fire. Being tired with our journey, we left them to enjoy the story, and rested ourselves after we lad offered a prayer of thanksyiving to God for his protection. 
September 23: I intended to pay an early visit to the king, and deliver my message, but he determined upon our drinking water first, that is taking breakfast before we commenced business; in the mean time he would summon all his head chiefs to hear the message from the king of the ship. About eight A.M., breakfast was brought in as last niglit, but the Krumen could not eat it. However, Aliheli succeeded in begging some cassada for them, which they greedily devoured. I was sorry that we were so situated as regards provision on account of the Krumen, and there was no rice to be harl, which is their proper food; I therefore opened a small tin of sardines we took with us yesterday for our lunch, and gave it to them with the remaining biscuits to make the best of it they could. At ten A.M., a message came from the king that he was ready to see me. Without loss of time, we soon marched with a large party of Filanis to the king's palace; and after having waited a short time under a tree in the street, while our arrival was announced, we were invited in. Large curtains of country cloth were suspended without and within before the throne; all the courtiers put off their sandals outside the entrance into the liall, and stuck their long spears, which they carry about with them as walking sticks, into the ground close by them. Besides Mr. Richards and Aliheli, I took Friday our lead Kruman and another into the king's palace, that they might see another court besides their own; as all the courtiers sat on the ground, we did the 
same close before the king. He was richly dressed in tohes made of broad yellow and green silk ribbands, and a rich yellow cashmere cloak, all of European manufacture, thrown over the tobes, and a rich carpet was spread at his feet. He had on a native cap, wrapped round with a white turban, and was seated on a mud bank richly adorned, which served for a throne. He was about forty year's of age, thin in person, and rather darkish in complexion, but of an intelligent countenance. As soon as we were seated before him, he saluted us many times over, in the Filani language, which Ibrahin interpreted in Haussa, and Aliheli into English.-He was very glad to see us. It was true he expressed his wishes to see some one from the white men's ship. His father lad been ling and his brother succeeded him, but they never heard of a white man's ship coming to their country, nor had they seen any one from the white man's country, as he had seen us. He thanked God for this peculiar favour; and now he was ready to hear what message we brought from the king of the ship. -I then told him that our Queen liad heard of his kingdon a long time, and of the large river which runs through it, as well of the Kowara which runs through Yauri and Rabba; that ships have visited the latter several times for the purpose of trade, and that it was the Queen's wish also, to see whether this river was as navigable as the Kowara, and for that purpose had sent the Sariki of the ship to see what sort of water it was, and the countries through which it runs, as well to make 
enquiry after a white man who had visited Yola sometime ago, and returner to Sokoto, but promised to return to some part of the bank of the Binue to wait for the ship: that the king of the ship hearing of his wisl to visit the ship, had sent me to invite him on board, and would be very glad to see him. I particularly urged him to get his subjects to cut wood for us to buy, and said that we would purchase about three hundred loads, in hopes of getting at least half that quantity if possible. There was plenty of dry wood in the way to Hamaruwa, but at the distance of five or six miles from the river, which made it difficult of carriage. He had not heard of Dr. Barth's visit to Yola, but knew that a white man was at Sokoto about two years ago: as to the river, there is he said, always plenty of water till next moon, when it would begin to fall and become very shallow. He wanted to know whether the ship intended to stop here and trade, or to pass higher up, that he might know what directions to give; but if any thing should happen to her, he should be blamed by Sariki Mussulmins (the king of the Mussulmins,) the Sultun of Sokoto, for neglecting to give proper information. I told him when he saw the Sarikı of the ship, they might enter into those particulars. As to trade, he promised if the ship would stay, to get as much ivory as she could carry in a short time. He excused himself from visiting the ship at this time, saying, that as he has seen us, it was as good as if lie had seen the king of the ship himself, and he was very thankful for my 
coming at his request. I urged that it was worth his while to visit the ship, which indeed was like a large house, as Ibrahim could tell him from actual knowledge; but he declined, and said he would think of it by the time the ship returned from Adamawa, if she was going up, and that he would communicate with the king of the ship by writing, respecting the water and the country between this and Yola, which was hostile to the Filanis. I then called the king's attention to the Heathen population in his territory, who I perceived still continued in their idolatrous practices. I told him he was aware we were Anasaras, and they Mussulmins, and asked whether he would have any objection, if trade should 'be established between us and them, to our making an attempt to teach and civilize the Heathens in his territory, according to our way? With a smile he replied, that it was all the same, he was willing: the smile, in which his courtiers joined, seemed to imply,-you may try if you can succeed. I then presented him with the red cloak which Dr. Baikie gave nne for him, and told him that I would report every thing he had said to the king of the ship. But he had been told by some one of the wonder I was performing in writing without ink, and yet, an impression was made on the paper; lie therefore requested me to write that he might see: I stepped close to him, and wrote Sarili Hamaruwa, the King of Hamaruwa,) and lie was not a little amused to see the words drop on the paper as the pencil moved on. Having elosed my interview with Mo- 
hamma by this wonderful performance, I left the court with heartfelt gratitude to God, for the success we had met with. Ibrahim remained with the king, and requested me to wait for him at home. I had told the king that I must return to the ship immediately, because I had not had an idea of the distance, and was expected on board last night, and that if we did not return soon, the anxiety of the gentlemen would be increased as regards our safety. We waited till noon, but no letter from the king had yet arrived. Ibrahim returned, and told me to wait a little more; and about one P.M., thinking it would facilitate our progress, I sent the Krumen away with two men from Ibrahim, to lead the goat and sheep onward till we should overtake them. I began to fear we should not get on board to-day, even if we succeeded in getting to Wuzu on the bank of the creek: in short it was not till three o'clock that the letter was got ready, and brought to my lodging, where it was rearl by the mallam who wrote it, and interpreted to me by Ibrahim in Ilaussa. The king wished me to come to the Palace before I left the town, which I did in my way; and I waited outside, while he ordered Ibrahim to present ine with a blue tobe of country manufacture, which was put on me, and a large blue country cloth for Dr. Baikie. They had been trying to catch a bullock for us to take to the Doctor, but the animals were so wild, that they could not succeed, but he promised to send one in a day or two. He replaced the lost honey by another 
pot; and a calabash full of fresh milk, and about two pounds weight of fresh butter were added to our presents; thus I took leave of Hamaruwa. On the way, I was told that the king was very glad indeed to see us, otherwise, we should not have had so early an interview; that many times, messengers from the interior had to wait thirty days before they could see him; that after we had left the palace, he sent one slave out to barter for three tobes to present to us, but the maker of the tobes was unwilling to give more than two tobes for one slave; and that the king was obliged to borrow the one he presented to me, hoping to be able to get the other two for Mr. Richards and Aliheli, when we returned again to Hamaruwa. I was glad at last to get on our way; but I doubted very much whether we should be able to reach the ship that night. It was not till eight o'clock P.M., that we reached $W u z u$, and I was glad to meet the Krumen all there in safety. I told Ibrahim to make ready for our embarkation for the ship, but he was afraid of being attacked by hippopotami in the night in the bush, through which we made our way to the creek yesterday morning. As there was no alternative, we consented to pass the night at Wuzu, though we had nothing to eat, but a little dry Indian corn which the Krumen parched for their supper. Wuzu being infested with musquitoes, not one of us had a wink of sleep till day-light, every one being occupied all night in brushing away the swarms of these insects from their persons. In and out of the louse the 
pest was the same; so that I sat with the Krumen near the fire which was kept up by three sticks, and constantly fed with grass till break of day. Although we had no change of clothes, and no covering, except what we had on when we left the ship, with which we waded through the water in our way to and from the town; we were better off than the Krumen who had nothing to protect their naked persons, and so they were more annoyed than we were. Towards cock-crewing, the cry of a wolf was heard a short distance from us. No doubt it was attracted by the scent of the sheep and goat tied in the yard where we lodged; the men had told us that the creatures were not safe where they were, but as we had no where else to put them, I left them to the chance of escaping during the night, or being carried away by prowling wild beasts. I sat down close by, actually watching whcther the wolf would come after the sheep, not to defend them, but merely to witness the attack in the habitation of man;-the fire lept blazing by the Krumen seems to have kept it off. When going to Hamaruwa on Friday, the carcase of a horse shot by mistake in the night by the farmers, was lying close to the road, but on our return next day, it was gone, carried away by the hungry wolves; so numerous are they, that the people go about always armed, ready to defend themselves against their attack.

September 2f: Sunday. As soon as it was daylight we liastened into the boat. The river has risen very much since Firiday, so that the creek 
has become an expansive sheet of water, and we were enabled to make a short cut into the main river, and about half-past seven o'clock, A.M., reached the ship to the great joy of all on board. Many and various thoughts had arisen about us, and every additional day and night of delay increased the anxiety. The joy was more than could be expressed in words, when they saw us arrive in safety, and with a good report of our reception. As the king had refused to come on board, Dr. Baikie at once determined to set out on a visit to his majesty. Having given him every information that he might prepare himself for the journey with less disadvantages than we, he, accompanied by Dr. Hutchinson and Mr. Guthrie, the chief engineer, left the ship about noon for Hamaruwa. At two P.M., I kept the afternoon service, and read the first part of the second Homily upon the Fall and Misery of Man, \&c.

The town of Hamaruwa is beautifully situated on a hill, rising on the south side of the range of the Muri mountains on the west side of the Binue. It commands a fine and extensive view. The river is seen stretching along like a narrow strip of white cloth, between the shades of light green grass, which fringes the water's edge, and a little further back is the darker green of trees, and then the blue ranges of Fumbina, with the lofty Mauranu mountain in Adamawa, on the left, and the Muri mountain in Hamaruwa, with their many fanciful peaks, on the right side, each at a distance of twelve miles from the river. In the valleys be- 
low the town, from one to two hundred beautiful cattle were feeding, and this gave life to the scenery. The houses are round, with conical roofs, built mostly of mud, about twenty or twenty-four feet in diameter. Many of these round louses are built in the premises of each master or head of a family, and enclosed with platted grass or fences which screen the whole group from the gaze of passers by. A narrow public street runs from one end of the town to the other, fenced in on both sides with grass, with now and then a lane or cross street. Except where the fences liad been neglected, the inner yard of a group of huts was not visible from the street. Now and then the front of some premises is open to the street, and the people pass their time there in the heat of the day, under the shade of trees. If the town of Hamaruwa were regularly laid out, according to the plan of a civilized country, it would present a very delightful appearance; but at the time of our visit, many houses had fallen in, and the sites were overgrown with grass; others were planted with guinea corn, while a large portion were only partially fenced in and cultivated. The town, though situated on a hill, with a rocky substratum, is yet sandy, and thus drics immediately after the fall of the rain; and though situated at the foot of the Muri range, yet is not so near as to suffer any inconvenience from it. $\Lambda$ t night there was perfect silenco in the town, no singing or drumming was heard, and the absence of light in the houses added to the dead stillness of the night. The inhabitauts lave 
no paln-oil, shea butter, nor nut oil for lights, and their sauce is made with cow butter. Cowries are not used, nor any other medium of circulation, but all is done by exchange, as in Zhibu. I had not time enough to inspect their market, but I think it must be very poor, and nothing like those held on the banks of the Kowara, and westward to the sea-coast. They procure water at the foot of the mountains, at a distance of nearly half-an-hour, and it is brought by the women in earthern pitchers, borne on the shoulder, because the mode of dressing their hair, plaited like a ridge, does not allow them to carry luads on their heads; many, however, who are not so circumstanced as to keep their hair always dressed in that manner, bear burdens on their head. Very few goats and sheep were seen in the town, and no fowls; perhaps, all these creatures are kept at their farms under the care of their slaves, but from the diffculty of purchasing any for the use of the ship, I think they can possess very few. The difficulty in getting horses to carry us from Hamaruwa to the river side, may, in like manner, be taken as a proof that they do not possess many, or else they did not wish to hire out their war horses for such a journey. Their slaves are chiefly employed in their plantations of Indian and guinea corn; but there is very little rice, although thousands of bushels of the latter might be cultivated to feed millions of people, the banks of the Binue being particularly adapted for the cultivation of this plant, after the fall of its mighty waters. The 
Filani themselves being military men, do not make agriculture their chief employment. They are very dirty in their apparel. It would seem that from the time tobes, shirts, trousers, and other garments are put on new, they are never wetted, except it be by rain, till they are worn to rags. With the majority, the tobes and shirts constitute their apparel by day, and their covering by night, and the trousers are often used as bags, in which corn or other things are carried. The reader may imagine what an amount of filth and vermin is thus accumulated. The females are cleaner in their apparel, and bestow more pains in plaiting their hair, and ornamenting it with flat pieces of brass, and learl, and copper rings, which are fastened on them in a fanciful manner. Large brass, lead, or iron ear-rings are suspended in their ears, and larger and ponderous rings of the same metals are worn round their arms, wrists, and legs, according to the means of the wearers; these metals, and some silver come across from the desert to the Bornu and Haussa countries, whence they are purchased from Noorish merchants, and brought to this part of the country, the traders receiving in return slaves and ivory. Many of the rings are manufactured in Kano and Katshina, in the Haussa country, and there are some Kano brass-workers even at Hamaruwa, who are carrying on their trade with much success; some specimens were bought from them. Dr. Baikie bought a pair of brass leglets, weighing five pounds, for which the man asked 45,000 cowries, the price of a slave, but he tonk much less. 
Traders from Kano and Katshina visit Hamaruwa in large caravans, and sometimes pass onward with other parties to Adamawa, where they purchase slaves and ivory, the former carrying the latter, and both are sold to the Moors in Kano or Bornu. There is a Katshina man here, who is trading for an Arab in slaves and ivory. $\mathrm{He}$ is the merchant who brought the suit of silk dresses and carpets in which the king appeared on Saturday, and which he sold to his majesty for fifty slaves. 'I hese have not all been paid, but when that has been done, another suit, still in the possession of the merchant, will be purchased. The slaves are used at the same time as beasts of burden, loaded with ivory, and marched to Katshina, Kano, or Bornu; in this way tons of ivory are yearly carried away from the banks of the Binue, and the country is depopulated by the slave-dealing Filanis. Sometimes the ivory and slaves find their way to the west of the Kowara, and thence to the coast. Two routes to Yola from Ilamaruwa were given us by Ibrahim; the one of fourteen stages, of nearly a day's journey each, round the Fumbina mountains, eircuitous but safe, being occupied by, or under the influence of the Filanis, and the other very short, of only four day's journey along the left side of the Binue, but so dangerous, that a part of the journey must be performed in the night. The part of the country where the natives are hostile to the Filani traveller, is called \%ena, and its inlabitants are said to possess many horses. The other unsubdued native tribes who are so mueh dreaded, 
are the Batshama, Bula, and Dampsa. We have been many times warned to take care of ourselves when we come in contact with them; for they are sure, we are told, to attack us, none of them being able to speak the Haussa or Filani languages, so that we shall not be able to communicate with them. On the back of Muri range, behind the town of Hamaruwa, are tribes of Pagans, called Wuruku and Zangale, who are said to be cannibals, and go about naked, some of whom have been conquered, and are now subject to the Filanis. Ibrahim was very proud of giving us the names of the principal states under Filani governors, who communicate direct with the sultan of Sokoto. They will be mentioned with the route to Yola in a subsequent page.

September 25: A great number of people visited the ship to bargain for clothes, in which they are very deficient: for their knives, spears, bows and arrows, rings, swords, wood, salt, \&c., they asked for cloth, and very little for other things in comparison. When they were thus engaged, it was very difficult to direct their attention to other things, every one being desirous to get what he could. Some rich Haussa traders brought swords, tobes, \&c., from Katshina and Kano to be sold on board; the swords are said to be made by the Gadamawa, whom I could not otherwise make out than as the Moors of Gadamis. The red silky wool is said to be brought by the same people in its dyed state, and sold in the Haussa country. In the evening, Mr. Guthrie arrived alone, 
having left Dr. Hutchinson at Wuzu waiting for Dr. Baikie, who had not then arrived.

September 26: About noon, Drs. Baikie and Hutchinson arrived. Dr. Baikie travelled yesterday alone, without a guide, and no horse. He missed his way, and was benighted in the bush, so that he was obliged to climb a tree, and pass the night in it. During the night, he heard the cry of leopards not far from him. The situation was a very dangerous one in a country so infested with beasts of prey; and we were all very thankful that nothing worse had happened, as God has thus far prospered us in our journey.

September 27: As there was no prospect of getting wood, and the season was advancing, it was decided that the steamer should proceed no further, but Dr. Baikie and Mr. May took boat for three day's sail higher up the river, leaving the mate in charge of the "Pleiad" till their return on Saturday. The other boat was sent to Wuzu, to kill two bullocks which the king had given to Dr. Baikie, for they were too wild to be brought to the ship in the little boat. Both boats being away, we could not communicate with the village till nearly the evening; when the mate went on shore, and came back, with a report that the river was falling. The apparent fall, however, was merely the cessation of the rapid flow, occasioned by a sudden copious supply from heavy rain, and, in fact, the river had not yet arrived at its height.

September 28: Early this morning the mate went on shore again, and reported that the rive 
had fallen two feet, and that he had been informed that it would not rise higher this year. Those interested about the ship advised her dropping down at once. I did not like leaving the two Government officers behind, among a strange people in an unknown country. If anything should happen to them, how were we to know of it at Zhibu, a distance of upwards of one hundred miles down the river, where it was proposed we should wait for them, trading meanwhile with the natives? The result proved, that the "Pleiad" might have stopped a fortnight longer off Gurowa; but under the circumstances, it was thought better to weigh anchor, and the ship began to drop. While the steam was being got up, the boat was sent for all hands from shore, and thus I was disappointed of my purpose, to spend some time on shore to ascertain the religious rites of the people, and by quiet conversation to collect as much information from them as I could. On Tuesday night, a buffalo, a leopard, a crocodile, and some ground pigs killed by some hunters, were brought to the village of Gurowa. No sooner had the hunters arrived with their prey, than shoutings, loud cries, and shrieks were heard in the village, in praise of the gods who had thus given them success in their expedition, and a great part of the night was spent in singing and drumming. The heads of the animals were cut off, and dedicated to the gods as their portion, being placed in the front of the gods' house. All Wednesday was spent in the same manner, shrieking and crying the praises of the 
gods. The head of the crocodile being a fine specimen, Mr. Dalton persuaded the hunters to sell it, but he had to pay a good round sum before the gods could be deprived of their rights. Although the village comprised no more than thirty or forty huts, yet it had two or three grods' houses. I asked a Haussa man resident in the place, whethes none of the Djuku, who are Filani slaves in this village, ever embrace Mohamedanism? He said, No, never. I asked why they were not taught to worship as the Filanis do? IIe replied, Are they not slaves? There is some improvement among them, however; and their females have substituted cloth for the leaves observed at Tshomo and other places.

With little steam the "Pleiad" ran down the river like a shot; in nine hours we made between sixty and seventy miles from Gurowa. All the high banks were completely covered, the river must have risen seven or eight feet since we went up about ten days ago. The country was flooded, on an average two miles inland, to the foot of highland on both sides of the river; creeks and large collections of lakes were visible to a great extent on both sides, and this, in part, may account for the absence of towns and villages immediately on the river's banks in this part of the country.

September 29: $\Lambda$ s there was no wood, we kedged down the river, which was difficult, on account of the number of islands, and the ship would not answer well to her lielm without steam, though the fan was unshipped. Unfortunately, about four p.xr., she drifted abreast of an island, and stuck fast in 
the mud, with a strong current on her starboard broadside; attempts were made, but she could not be hove off this evening.-

September 30 : Last night a terrific tornado blew, with copious rain, thunder, and lightning; the ship was dashed against the bank with great violence by the strong wind and current, and driven more on to the bank. I felt less for our own situation than for those whom we left higher up in an open boat; however, they were resigned to the care of that kind Providence by whom we have been preserved to the present time. Efforts were resumed to get the ship afloat; every combustible material that could be spared, such as empty boxes, casks, useless paddles, \&c., were split for fuel to get up steam to assist manual force, but, unfortunately it was discovered that the bilge injection was blocked up with the mud, so the engine would not work. The little steam was, therefore, blown off, and the only chance of getting afloat now, depended upon our personal exertions; but nothing was effected to-day. From the rains of last night the river rose very perceptibly, and this gave a good hope of success, though some began to entertain doubts of it, and to talk of her probable abandonment. Three canoes were seen on the other side of the river, but they would not come near us.

October 1: Sunday. The labour of getting the ship afloat, was resumed early this morning; the Krumen worked hard, but repeated failures after many laborious attempts discouraged them much. The fear that she might liave to be abandoned 
was still entertained by some. I felt still more uncomfortable on account of Dr. Baikie and Mr. May who were left behind, and was very anxious for their return in safety. At noon, when we were at lunch, the Krumen, who likewise had been anxiously looking out for the return of their countrymen with the boat, gave loud cheers when they saw it coming at a great distance. We were all instantly on deck, and were glad to see the whole party safely on board. They had made a voyage of thirty miles higher up the river from Gurowa; and reached the following villages:-Tshomo, a mile from Gurowa on the right side; Lau, higher up on the left, Bandawa, Djin, Abiti, and Dulti. The people call themselves Baibai, the same as the Djuku, or inhabitants of Kororofa. Batshama on the right, and Dampsi on the left, are independent of the Filanis, the other places are more or less under their control. They remain in their wild and uncivilized state; at Dulti they live like amphibious creatures in their flooded village. Their propensity to pilfer became manifest from their rude familiarity, handling every thing about the gentlemen more than was pleasant, and an attempt to stop the boat, was a sufficient warning for the explorers to get out of the midst of this people with all speed; while they were making their way out of the grassy creek, the natives pursued them in the canoes, if possible, to seize and detain the boat, with a view no doubt to plunder them; nor did they return from pursuing them, till the boat had fairly got into the open river. Our party returned to Gurowa on Saturday morning, and were quite disappointed 
at not finding the "Pleiad" there; but they received notes informing them of the cause, and apprising them of our intention to drop down to Zhibu. They weathered the heavy tornado of Frialay night in the open river, exposed to the inclemency of the weather, rain, thunder, and lightning. On Saturday, they attempted a new passage through a creek which they supposed would lead them to the main river a short distance below, but instead of this, they were led to an extensive lake formed by an immense spread of water over a large space of ground on the left side of the river, and here they were obliged to pass the night, not reaching the open river till about half-past eight A.Mr. to-day. After not much more than three hours' pull, they saw the "Pleiad" at a distance, which they suspected was aground. We had much cause for thankfulness to God for bringing them back safely, after passing four nights in an open boat. All efforts to get the ship afloat to-day were fruitless; in consequence of this, we could have no service. At lialf-past seven P.Mr., I read the Evening Prayers in the saloon, but only some of the officers could attend. 


\section{CHAPTER IV.}

RETTRN OF THE EXPEDITION-DEPOPULATED STATE OF THE COUNTRY-ITS TRADE, RELIGION, AND LANGUAGE-ZHIBUATTEMPT TO VISIT WUKARI-SIUFFLING CONDUCT OF THE KING-GOODWILL OF THE CHIEFS AND PEOPLE-PROGRESS TO ANYIEII-FAVOURABLE INTERVIEW WITH AGBO AND THE NEIGHBOURING CHIEFS-VISIT TO ANUFO-OPPRESSION OF THE FILANIS-HUMILIATING POSITION OF THE CONQUERED CHIEFS - INTERVIEW WITH THE CHIEF OF ROGANJKOTO-REPORT OF THE MESSENGER FROM KEANA CONCERNING THE TWO WHITE TRAVELLERS-EKEREKU-RAPACIOUS CONDECT OF THE FILANIS - ABATSHO-MOHAMMA CHIEF OF PANDA-AMARAN MARKET-REPUBLIC OF YMIMAHA-KINDLY RECEPIION TIERE-DESTRUCTION OF PANDA BY THE FILANIS - WILLINGNESS OF THE PANDA PEOPLE TO TIRAE AXD RECEIVE MISSIONARIES-RETURN TO THE CONFLURACE.

October 2. The labour of getting the ship afloat, was resumed with the united efforts and assistance of Mr. May and Dr. Baikie; and to the joy of us all, our object was effected about three P.x.; the continued rising of the water greatly assisting us. At noon, a canoe was seen pulling up, and stopping among the grass to look at us; she was hailed alongside: she came from Zhibu, about twenty miles below us, and had on board as passengers, two Haussa traders, men of Bautshi, who were returning from Zhibu with two slaves and some ivory which they had purchased. The 
ivory was bought from them in exchange for cowries and some goods; the slaves sat in the canoe unshacklcd, as there was no chance of their escape when travelling on the river, but they had on board the irons to secure them, two pairs of which were purchased by Dr. Baikie. The canoe had to pass the night among the bushes, because there were no villages near the water-side for them to put in. I asked about the population of this part of the country, and was told that from Zhibu to the Akam, or Kankundi river, and five day's journey inland from Zhibu, no human habitation is to be found. I asked, what had become of the inhabitants? They replied, they had all been carried away captives to Sokoto. I asked of what nation were the slaves they had on board; and they said they were Baibai, of the town of Gomkoi, a tribe of the inhabitants of Kororofa, who had retreated into the interior, and there maintained their independenco in some lilly localities secure against the inroads of the Filanis. They said travellers must sleep five days in the bush before they reach Gomkoi. I asked whether the people of Gomkoi had horses; they replied, that horses are taken across that way from Bautshi, and exchanged, five slaves for one horse. I showed them pieces of iron, called "Kantai," which I got from Hamaruwa, the use of which, I had not the opportunity of learning at the time. They said, they were used as currency, one hundred such pieces, being the average price of a slave. I asked whether the inhabitants of Gomkoi were Pagans or Mohamedans; and was informed, that they were 
all Pagans; that the males wore some sort of cloth around their loins, but the females, only a few green leaves. On asking whether they were cannibals; I was answered in the negative. I then inquired the name of the country on the right side of the river. They said, Bautshi, and told me that we were nearly opposite the village of Dali, the smoke from which was visible; from Dali one goes to Dampara, and then to Wazai, and on to Yakoba. I asked what language was spoken at Bautshi, and they said, the Haussa and Filani, but that Haussa is the prevailing language, though the country belongs to the Filanis, and that Mohamedanism is the prevailing religion.

On their departure, I requested them to use the poor slaves kindly, the only help I could render to the poor unfortunate sufferers. When the traders were on board, a canoe was perceived issuing from the bush with five or six men in it; on looking at it with the glass, the people were observed busy making some strange gesticulations towards the ship, as if they were performing some incantations, whether for her detention or departure, or invocation to her as a deity, we could not learn. The men were marked with white chalk in long streaks on their bodies, as worshippers of the gods are distinguished at the time of their devotion. They had been in sight about an hour, when the canoe from Zhibu came up to them, and I believe spoke to them. In a few moments they left the spot, and followed the track of the traders up the river, and both were soon lost sight of. 
October 3: Started at eight A.M., to drop down, and anchored off Zhibu at seven P.M.; at eight o'clock, a gun was fired to announce our arrival, the town being about a mile from the river. The high banks we left about three weeks ago were completely covered, and the flat ground overflowed a considerable distance; the corn-fields, where the people stood to sell their articles, and the chief rode about among them to keep them in order, and where our Krumen cut wood for fuel, were now navigable for boats and canoes to the very foot of the hill where the town of Zhibu stands.

October 4: Early this morning we dropped a little lower down, for the convenience of wooding. Dr. Baikie, not feeling quite well, requested me to communicate with the chief, and to tell him of our intention to visit Wukari through him, and to ask him to supply us with loorses and messengers to take us thither; a velvet shirt was given me for him at the same time. Having ascertained the possibility of visiting Wukari from this place, especially as messengers from the king of Wukari were herc, I returned on board to inform Dr. Baikic, and that the final arrangements for the journey required his presence.

October 5: Went to the town on the subject of our journcy to Wukari; everything secmed fair and promising, but the difficulty was about getting horses; owners were not willing to hire out their horses for the journcy, under an excuse that there was so much water on the road, and that if their horses made the journey, they would die on their 
return. It took us some time to reason the chief out of this pretence; he then said, they had not more than five horses in the town, which we positively denied to be true: he then said, we should have three horses to take us to $\mathrm{Zu}$, half-way between here and Wukari, where we must stop overnight, while the messenger goes to Wukari to fetch horses to meet us. $\mathrm{Zu}$ is a market-place, where peoplo from Zhibu and Wukari meet for trading and return, but it is not inhabited. I asked him whether it was kind in him to let strangers from a far country sleep in the bush for want of a conveyance, when the journey could be made in a day without such exposure? He had been coveting another sword from Dr. Baikie, under the false pretence, that the one which was given him three weeks ago was broken, and sent to the blacksmith for repair. We asked to see the broken sword, but it was never shown; and thinking this a favourable opportunity to satisfy his covetousness, he asked for three swords if the horses were to take us to Wukari. He was told of the unreasonableness of his demands, and we asked, if he, alone, were to receive four swords, what we were to give to others? However, the Doctor was willing to sacrifice another sword to his avarice, and to pay him in addition 20,000 cowries, to which he agreed, and the messengers were particularly requested to be ready with the horses early next morning, so that nothing might delay us. Having completed our arrangements, we returned to the ship, but with some doubt whether we should get the horses. Wo have made up our minds, however, in case of disappointment to 
perform the journey on foot, if we could procure a guide.

October 6 : Early this morning we left the ship according to promise, and went to the king's house. We found him sitting in the outer entrance talking with one of his headmen, and with a furrowed countenance, indicating sourness of temper and feelings of dissatisfaction. We saluted him, but our salutation was coolly returned. We then told him we were ready to start for Wukari, according to the arrangements of yesterday. He wanted to know why we did not go first to the Galadima, his chief officer, and come with him? We began to apprehend difficulty; however, a messenger was sent to call the Galadima, who came without delay: the chief then asked why we did not pay first, before we had the horscs? We asked him whether he thought we were liars, or that we had come from our country thus far to deceive? After many vain and groundless excuses, it was proposed that the sword and cowries should be sent for from the ship, and the cowrics measured before him, to show we had no intention to deceive. Dr. Hutchinson returned to the ship and brought them; but no sooner did the chief see the sword, than lie said, the sword he wanted for himself, but cowries were of no use to him, and that he must have cloth in their stead. This was sufficient eridence that he was deceiving us; and we would lave performed the journey on foot with the messengers from Wukari, but they were under his control. They said they were not ready, having to prepare their food for the journey; we offered to feed them 
from our own provision, but they still shuffled, till at length, seeing plainly that the king was befooling us, Dr. Baikie deternined to show his independence, and told him that when the vessel next returns to the river, it will go to Hamaruwa, and report his treatment of us to his master; reminding him that we were not his boys to be treated in a manner so unbecoming a king. We then took our cowries, and sword, and luggage, and returned to the ship. Before we got into the boat, a messenger was sent to call us back, but as we had been so much deceived, we would not listen to him, but told him that if the king had anything to say, he should send properly to us on board. About an hour after, a canoe was sent with a message from the Graladima, to call us back, intimating that he had been blaming the king since we had left, for his bad conduct to us. The messenger was sent back with many thanks to the Galadima for his kind interference, and to tell him the object of our visit to this country, and assure him that our intention in visiting Wukari, was more for their advantage than for our own. In proof of this, I showed him a tumbler, a carving-knife, some biscuit, bread, and salt meat, and asked him whether they were not superior to their calabashes, Indian corn, and the roughmade knives wo bought from them for inere curiosity? I told him, noreover, that by hindering our visit to Wukari, the king only acted against the interest of the country in gencral, and that when he had once deceived us, we could not believe him any longer. A short time after, the Galadima himself 
eame off with the king's messenger and his own, to mediate in person between us and the king. He said that the king had done very wrong, and had been blamed for it by him, and that he would guarantee for our visit to Wukari, whether we wished to start to-day, or to-morrow morning. Considering the effort this generous-hearted man was making on our behalf, after showing him the great interest we took in the country, and explaining to him that the conduct of the king was ealculated to turn it into another ehannel (as he evidently saw and acknowledged), we promised to eonsicler the matter till the afternoon, and then we would let him know our intention. Ile begged of us not to disappoint him, and desired us when we went to the town, to go to his house, that he might aecompany us to the king and reconcile us, and then make arrangements for our journey to Wukari to-morrow morning. He then left the ship, with the promise of a visit from us in the afternoon. The people were quite chispleased with the king's conduct towards us, and were at the same time afraid to eome on board to trade, as we had left the town this morning in displeasure; but the Galadima was told that our matter with the king neel not prevent the people's coming to trade, and that they had no cause to fear. According to jromise, after four o'clock, I started for the town. Mr. Richards aecompanied me, and we went to the Galadima's loouse. He was absent from loone, beeause a man was being installed this day as Sariti $n$ doki, i. e. the king of the horsemen, or head of the cavalry. There was drumming and war dances, 
with horns blowing, and soldiers parading the town with as much excitement as if they were going to storm a city. The Galadima was told that we were come, and the whole train followed him to lis gate. The warriors armed with bows and arrows, and spears, moved towards us in partics of six or ten with speed, and then made a sudden stop, shaking their weapons towards us with an air of great selfimportance. The women stood by the fence shrieking their cry in praise of the Sariki $n$ doki, who was riding a fine young steed belonging to the Galadima. The horse was led by a man with a cord in his hand, to prevent accidents among the crowd, as well as to save the Sariki $n$ doki the trouble of watching his carrier, as to-day was to him a day of pleasure and ease. I had expected to see the people in their holiday vest, to-day being also Friday, the Alitshima of the Mussulmans, in which they partially abstain from their ordinary pursuits. I was disappointed, however, for with but few exceptions, they were as dirty and ragged as at other times. The procession passed on, and we entered with the Galadima into his inner yard, and he seated us in his praying ground, a space of about twelve fect square enclosed by four sticks, to discuss the subject of our visit to Wukari. He gave me many thanks for coming according to promise, and said that he had blamed the king much for his unfair dealing, that he only retains the title of king, but that he, the Galadima, was the chief manager of public business, that we might make ready for the journey to-morrow morning, and that we should 
give the sword, which the king desired for payment, with three measures of cowries $(30,000)$, or, if we liked, three red shirts instead of the cowries. Our stock of red shirts was nearly exhausted, I, therefore, agreed to pay cowries instead. I then asked how many horses we were to have; he said he was sure of lis own, and one from the king, but the owner of the third had not yet been asked, and it was not certain whether he would let it or not, but that the king would ask him, and pay for the horse. I wanted to know the certainty of obtaining the third horse, and whether the king would take the cowries he had refused this morning, and I suggested that it would be better to go and decide the matter finally before his majesty. He was in the shed, performing his devotions when we got there; and while we were waiting in the hall by a faint fire of two or three sticks, which gave more smoke than light-a specimen of a Filani lamp-the Galadima performed his devotions also; it was then about sunset. About ten minutes after, the king returned, and he and the Galadima harl a long talk in Filani. He then thanked me for coming and made many frivolous excuses, laying all the blame upon the messengers, who were not willing to go, because they were not first paid. I asked what payment he wanterl now? He said he wanted the sword, but not cowries, and if the cloth we would pay him was good, he would take it. I asked how many horses we were to have? He said, he was sure of his own and the Galadima's, and that he would try to speak to the owner of the third this 
evening; that we might hear the result when we came in the morning. I told him we had spent three days already in talking about going to Wukari, and had been disappointed; if I were to go to the ship, and tell the gentlemen to make ready for the journey, and the horses could not be procured, or the quality of the cloth for payment were to be disputed, what were we to do? And meantime, the sun would be as high as it was this morning, which was one of the objections made by the messengers. However, without further bargaining, I told him, I would report what he had said to my Sariki, and he would decide for himself. By the time we passed the gate of the fortification, about seven P.M., it was being fastened with sticks piled across the entrance; so that we had to climb up and jump outside. At this hour, none of the inhabitants were seen outside the town. As we were walking towards the town with the Galadima's messenger, he showed me the mark to which the fortification was to be removed, about 200 feet in advance of the present: and said the new sticks we saw at the water side were for it. This made me inquisitive as to the need they lad to fortify their town? He exclaimed in Haussa, " $A h$ Wukari halbi;" i. e., Als, Wukari shoot arrows! As I did not wish to lose a single word of what he was going to tell me about Wukari, I called Aliheli to me, that he might hear all perfectly. I asked him to proceed, but he was on lis guard; and said, when the first attack was made upon this place from Hamaruwa, the inhabitants of the towns, whom he called Zuntu and Garba, resisted for ten days before 
they were conquered, and since that time Zhibu had had four kings-two had died, and the third was too old to do business, and resigned the kingship to Zumbade, the reigning sovereign. In the mean time we entered the town, and the subject was dropped. The people of Gandiko had told us that they had had war with Wukari, and were not able to conquer it, but had remained there since. The chief of that place made the state of enmity between them an excuse for not letting us visit Wukari from their town. The great distance between Zlibu and Wukari keep them one from the other, though there is a neutral market at $\mathrm{Zu}$, where they meet at times for trade and barter. Though they exchange messengers one with another, yet the fact that the space of a whole day's journey is without inhabitants, shows plainly that their professed friendship is a hollow one. I returned to the ship and reported the results of my visit to the Doctur; and the way not being clear for our proceeding to Wukari, the attempt to reach it from this place was given up.

October 7: Mr. Richards was sent to thank the Galadima, and to tell him, that having lost three days' already, we could not visit Wukari from Zhibu at this time, as the water was falling. The Galadima was very sorry, and went with lim to the king to report the message from Dr. Baikie. Mr. Richards sail, the king, as a cunning rogue would do, attempted to charge us with duplicity; saying, that we had charged him with a breach of faith yesterday morning, but now we liad acted the same part. Why did we now refuse to go to Wukari, 
when he was ready? Perhaps it was because 30,000 cowries were asked. Truly, he would have been glad to have got the sword, but the king of Wukari would now suspect him of hindering the white men from paying lim a visit. In this and many other ways he tried to clear himself from blame.

October 8: Sunday. Had service at ten A.M., and read the second part of the second "Homily on the Misery of Man, \&c." All hands rested, and it was the most quiet Sabbath we have enjoyed since entering the Tshadda. After six days' hard labour, the body as well as mind need rest on the seventll. God saw the benefit of it to man, as well the honour he claims to himself in separating that day as his own.

October 9. Having got sufficient fuel to take us to another wooding-place on our way down, at ten A.M. we started from Zhibu. The inhabitants who were busy enlarging their town by removing the fortification, stood gazing at us till we glided out of sight. When the present fortification is finished, Zhibu will be about four miles in circumference. About one P.M., we anchored off Gandiko, when Ama, the chief, immediately sent to salute us, and sent some Guinea corn as a present to Dr. Baikie, and the ship's company. This we returnerd by a few yards of calico. The face of the country about Gandiko was entirely changed by the overflowing of the Binue to the very foot of the high ground upon which the town is built.

October 10. Having given the people oppor- 
tunity to sell what they had, we got under weigh

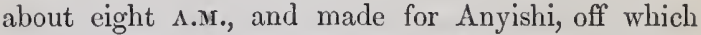
place we anchored about two P.M. Here we had the misfortune of losing our best anchor and cable in seven fathoms of water; the whole chain having slipped from its fastening. It was a serious loss, as we had now but one anchor and a kedge left, two kedges having been lost before. Agbo, the chief of Anyishi, immediately sent to salute us with a present of two fowls and some eggs; and we promised to go on shore and pay him a visit, which we fulfilled after dinner. Anyishi is a small village, situated on a hill rising on the west side of Mount Herbert, and separated from it by a valley. The town is rudely fortified by low inud walls and a ditch, all of which greatly need repairs. The huts, about forty in number, are scattered about upon the liill, and the spaces between them are planted with corn and other vegetables, in a very irregular manner. We met the chief outside the group of his huts, sitting upon buffalo and leopard skins. We at first attempted to communicate with him through Haussa and Djuku interpreters; but the Djuku interpreters not being expert enough, the chief himself addressed us in the warmth of his heart in the Haussa language. On I)r. Baikie's mentioning that he was sent to enquire after the welfare of the country, and to see if there is any prospect of opening trade with them, the chief gave thanks ten times over, for ho could not express himself enough in words to convey the feelings of his heart. When he was told of our 
various attempts to visit the king of IVukari, and our disappointment, he was very sorry, knowing how very glad the king would have been to see us. He said that his people were mueh oppressed by the Filanis, and the Berebere of Zaria, and Lafia, who came aeross two years ago, and drove them away fiom their old town, Sundube, from whenee they took refuge at this plaee; that when they lived undisturbed in their homes, they hunted elephants; that at one time he had plenty of tusks, which he plaeed in a row in his hut like sticks, and spread his mat on them for his bed; that some of them were seeured in his flight, others were earried away by the enemy, and the rest were burnt in the hut; and that they had lost many of their people, wives, and eliildren. He pointed out one man from the five messengers, sent by the elief of Anufo, the neighbouring village, as a person who had been eaught by the Filanis of Gandiko, whom they eall Katshala, and who had lately effeeted his escape. He said that it was simply owing to such disturbance from those who were stronger than they, that they had beeome poor and lave nothing. We asked the distanee from Anyishi to Wukari, and he gave it as three good days' journey, namely, from Anyishi to Akwona about ten hours; from thence to Arufu or Afiayi, two neighbouring towns, twelve hours; from Arufu, or Afiayi, to Wukari, twelve hours. As the chief told us that he had sent to the chiefs of the neighbouring villages, who he hoped would eome to see us to-morrow, we postponed leaving a message for the king of Wukari till then. Large lumps of lead- 
ore just landed from a canoe were seen in the town: it was dug at Arufu, one of the halting places to Wukari, where there is a mine, from whence it is conveyed to Keana, in Doma, for sale. Dr. Baikie purchased several large lumps, of from ten to eighteen pounds weight, for specimens.

October 11: After breakfast we went on shore, to trade, as the canoes could not come alongside on account of the strong current-they liad made several attempts, but were in danger of being upset. We took our seat under shady trees, when we were immediately surrounded by a large number of people. Trading was going on, on the one hand, while on the other, I was watching every opportunity of engaging the attention of some one in friendly conversation. Among the people around us, were some respectable-looking men, whom we recognised to be Mitshis, by the peculiar marks on their foreheads. One of them had a pipe which attracted my attention, and which I bargained for, and soon purchased with a razor. I asked where it was made, and was answered in the Mutshi country-for so they call themselves, while their neighbours called them Mitshi. I asked whether any Mitshi people were living in this place, when one of them introduced limself to me as the chief of a Mitshi village not far off; and several other Mitshi people were pointed out among the spectators. I engaged the attention of Njoro, the Mitshi chief, whose town is Iwom, not very far fron Anyishi. Njoro spoke Haussa fluently, and as I had no interpreter, I tried to make myself understood as well as I could. When I told him 
that our Queen had sent this ship to see if the country was at peace, that she might think of opening trade with its people; he interrupted me by asking, "What is the name of your king?" (for Queen) I told him 'Victoria,' which he made several attempts to pronounce after me, and said, "Your king is a true king; your king is a true king." When I told him that good people in our country always felt very sorry when they heard that people in this country fight and catch one another for slaves, which thing depopulates the country, and lays the land waste without inhabitants; he burst out with enthusiastic rapture, shaking me by the hand, and asked for the name of our king again, as he had forgotten it, and said, your king is a true king; and then with inexpressible emotion he addressed the Mitshi people who were there, in his own language, which of course I did not understand. $\mathrm{He}$ said they all belong to the king of Wukari, whom they were sorry we were not able to visit; that the king would have been very glad to see us, but that all they have heard would be reported throughout the country, which he said was very extensive inland. I wanted to know the boundary between the Mitshi country, and that of Kororofa, but he said, by inserting his ten fingers between each other, that they were thus mixed together as one people-here is a Djuku town, there is a Mitshi village for many days' journey inland. I asked whether they all speak one language? when he answered in the negative. The Djuku language is quite different from that of the Mitshis I then requested him to give me the 
numerals up to twenty in Mitshi, which he did, and I pencilled them down in my note-book, to the astonishment of the bystanders. 'To cement our friendship, I produced a red cap from my bag, and placed it on Njoro's head, when all around shouted as a sign of approbation, for the honour done to the Mitshi chief. Here again I must acknowledge the kindness of Lady Buxton, by whom I was furnished with this useful article, as well as many others. Dr. Baikie returned on board, as Mr. May was coming on shore to take some observations, so he gave me a message and present for the chief of Anufo, the neighbouring village, whose messenger had just come to lead us thither. Dr. Hutchinson and myself then started for Anufo. The path lay between hills and valleys on the back of Mount Herbert, very close to which we passed, the soil is rocky and poor on the hills, but black and rich in the valleys, where Guinea corn flourished greatly. Just before we entered the town, we observed a small portion of land sown with beni, a very useful produce for commerce, which might be extensively cultivated here, as might cotton also, if the inhabitants were permitted to be at rest, and a market were opened for the produce of the country. The town of Anufo, situated on a small hill on the east side of Mount Herbert, about two miles from Anyishi, is a neat village, clean and airy, fortified with walls and ditches around it. We were seated under a shady tree, waiting for Mr. May, who, we expected would come after us when he had finished his observations, and had been there about an hour, when 
Abiki, the ehief, sent for us. He was quite a young man, sitting on buffalo and leopard skins under a shady tree outside the group of his huts. After the usual salutation, we took our seat and commenced business. The chief's Galadima, or next headman, acted for him. The eonversation was carried on in Haussa, interpreted into Djuku, although I believe he understood IIaussa as well. In the meantime, Dr. Baikie sent me a note by Mr. Dalton, with a message to the king of Wukari, expressing his regret at not being able to visit the king this time, and a hope, if the ship eame out again, that he might be able to fulfil his wish next year. This message I delivered, stating the objects of our intended visit under two distinct heads, for the easicr digestion of his majesty: first, I saic, we wished to know whether he was truly desirous that a treaty of legal trade should be made between him and England: and secondly, whether he would not like, at the same time, that his people should be taught tọ learn God's book, and worship God as we teacli people of otlier countries? To both of these questions, the Galadima, and a man from the king of Wukari, who was shortly to return thither, gave separate answers, as conveying the wishes and feclings of their king; but promised that the message would be faitlffully delivered. They hoped God would keep them in safety till the ship returns 11ext year, for they are always in doube when they have passed one season without molestition, whether anotlier will be as favourable, and said that in all probability we might not meet them 
here next year. I encouraged them to look up to God for protection, and told them, that many good people in our country pray for their preservation, and that war and the slave-trade may cease from the face of the earth. I gave the presents from Dr. Baikie, for which we received a kid in return. Njoro, my Mitshi friend, had returned from the ship, to which he was taken by Dr. Baikie, and followed us to Anufo. We asked whether horses could be got here, to make the journey to Wukari, should the gentlemen return next year, and wish to do so. Njoro replied, that ten horses could be got, if we wanted as many. $\mathrm{He}$ was anxious that we should visit lis village, but it was too late, being nearly four o'clock. Since we entered this river, this is the first time we have come direct among the oppressed inhabitants without being immediately under the watchful eye of their Filani oppressors; hence they were free to lay their griefs open before us, and to desire the friendship of the white men, as the friends and well-wishers of all mankind. Though Anju, the king of Wukari, pays tribute to Bautshi, yet being a Djuku by birth, he sought the protection of his people, and they in return have an affection for him as their lawful sovereign.

At Zhibu and Gandiko all the Djuku people, though under the Filani as slaves, were very anxious for us to visit Wukari. They dared not say it openly before their masters, but they were open and free enough when they came on board. The man from whom I collected a few Djuku words 
to compare them with Koëlle's specimens, whose name is Anju, the same as the king's, was rcady to accompany us to Wukari if we sliould detcrmine to make the journey. Zumbade or Bohari, the king of the Zhibu district, Ama the chief of Gandiko, and Garike of Gankera, are all of Djuku race, but have by usage become so amalgamated with the Filanis, by embracing their religion, and to secure their fidelity to the interest of their masters, that they are placed in posts of honour to govern the mixed population of Djuku, and those who are half Filanis by birth, whom they lead out to battle for their own interest, and for the interest of their Sultan. They all go by the name of Filani, but in reality they are not so by birth, but by conquest and adoption of the customs, language, and religion, of the conquerors. Wc had not secn a real Filani, till we came to the neighbourhood of Hamaruwa. 'This will be a sufficient explanation of the hollow friendship between the inhabitants of the Zhibu district, and that of Wukari; they are in fact the same pcoplc, but the former liave become instruments in the liands of the Filanis to oppress their brethren, whose welfarc and safcty the king of the latter has at heart. Sliould another experition be sent out, and a visit to Wukari be thought desirable, though the way from Anyishi is long, yet if horses can be got, it appcars to mc to be the lucst point from which to make the journcy, from among the subjects of the king who takc intcrest in the visit. An opportunity would also be given of making accurate olsservation 
in the lead mine in Arufu, and the country and people would be better known. Then again, as soon as the people of Gandiko and Zhibu see that another way has been found to Wukari independent of them, they will lay aside their vain and selfish excuses, and the nearest road-waythat from Gandiko is only about seven or eight hours' journey-will be laid open for future visits. Another inducement to the chiefs of these latter places, will be the advantage of the ship laying off their town for a much longer time, which they would lose by declining to promote such a visit to the interior.

October 12. Steam was got up as soon as possible, and for about an hour and a half, an attempt was made to fish up the anchor and cable, but in vain. It required steam to be kept up in full power to stem the current, which ran four and a half knots between Mount Herbert and Mount Adams, and we were obliged to give the anchor up for lost, and take our departure downward with the stream. In about four hours we made Rogan-koto, a distance which occupied us a day and a half in going up. We anchored off Rogan-koto according to promise, to give the people opportunity of trading, and also that we might get wood for fuel. We paid a visit to Jada, the chief, who was very glad to see us, and earnestly asked after our welfare. He said, that they were very - much alarmed about us, because it was rumoured down the river that we had been attacked by the people higher up, and had had a dreadful battle. We told him on 
the contrary, that we were welcomed in every place we had reached, the great king of distant Hamaruwa not excepted, at which he was not a little surprised. Here we met Onuse, Ojogo's sister; she was the first to come on board, and give us an affectionate salutation. She told us that Zuri, our messenger, had returned from Keana, and was at Ojogo; the nature of the communication he brought from the king of Keana she could not tell, but no white man had come with him.

October 13. A great many people came on board to trade in provisions, and various curious articles, and plenty of wood, so necessary for the navigation of the ship, was bought up. How different the people of Rogan-koto from those of Ojogo! The latter could not be moved to bring a few pieces during the whole of the twelve days we spent with them, whereas the former were all readiness to supply us, men, women, and children, turning out to bring wood; and all consequently reaped the price of their industry. In the afternoon I walked to the neighbouring newlybuilt village of Kondoko, which has been removed hither since we went up, the people being driven out of their old village by the rise of the river. On my return from Kondoko, I fell in with two Mitshi men at Rogan-koto, from whom I added a few words to my collection, and gave each of them a handkerchief. $\Lambda$ mong many other things brought on board, was some rough beaten iron in the shape of hoes. As I perceived they could not have been intended for tillage, being entirely different from 
hoes used for that purpose, and unfit for it, I was inquisitive to know their use. I was told that it is the currency of this part of the country, from Doma to Katshina, at which latter place it appears they are manufactured for trading purposes. Thirtysix of them is the average price of a slave, as one hundred Kantai are in Hamaruwa. This singular currency is called Akika, in Doma and Kororofa; Ibia, by the Mitshis; and Agelema, by the Haussas. I have purchased a few specimens which I shall send to England as curiosities.

October 14. Got under weigh at eight A.M., and anchored off Ojogo about nine, to take on board Zuri, who was our messenger to Keana, to enquire after Dr. Barth. The intelligence Zuri brought was, that the two white men, with their two servants, were said to liave left Keana for Doma, and from Doma liave gone to Toto, and thence to Abazhi, about forty-sevell days previous to his arrival. How far this information may be correct, we cannot say; but we may liave an opportunity of verifying it at the Confluence by enquiry from those who come down the river from Egga, or the neighbourhood of Rabba. We left Ojogo about twelve A.M., and anchored off Akpoko about three P.x., and landed to visit Magaji, the old chief, who received us with a hearty welcome, and was surprised to liear the distance we had made since we left him. The rumour that we had been attacked, and several of us killed on the upper parts of the river, had also reached Ojogo and Akpoko, and they were all thankful to see us return in safety. 
October 15 : Sunday. Got under weigh at six 4.M., and anchored off Dagbo about eight o'clock, where we stayed the remainder of the day, intending to wood here to-morrow. But the whole of the farms, with all the houses, were under water; and the inhabitants had quitted the spot for their old town on the baek of the creek, that being now secure against the Filanis, whom the water kept at a distance. Had service at half-past ten, and read the third Homily on the "Salvation of Man," \&c.

October 16. Some wood was collected from the water, and cut ready for use. In the afternoon we dropped down below Dagbo, opposite the villages of Eruko, in the Bassa country, to which Dagbo is subject. These villages had been visited and burnt down by the Filanis a few months before, and some of the inhabitants had escaped to the left side of the river, while others fell into the hands of their pursuers. The remnant liave returned and rebuilt their houses, and planted their lands; but one half of the buildings are falling into ruins, beeanse the owners are destroyed. As the king of Bassa had returned from his flight to a small village a short distance fiom the river, we purposed to pay him a visit the next morning.

October 17: Started early this morning in company with Dr. Iutchinson, Mr. May, and Mr. Richards, after the rain, on a visit to the king of Ikereku. There liad been rain all night till the morning, which made the road clean, and the walk pleasant and agreeable. Two and a-half miles 
brought us to the two small villages which at present go by the name of Ikereku, the capital, or residence of the king, the old Ikereku being about fifteen miles inland. It is said to have been more populous than Igbebe at the Confluence, and to be at a distance of four days' journey from Panda, and ten from Doma. Adama the king, is a middle-aged man, whose title is Agabi, the name of their old country Gabi, whence the Bassa pcople migrated to this part of the country; lence the title Agabi is taken by all Bassa kings. They were at one time the dread of their neighbours, to whom the Agatus, a tribe of Doma, were once tributary. Ikereku had been trice attacked before by the Filanis, but they were repulsed. But the Agatus, their dependents, were taken away from them at the conquest of Doma, by the Filanis. The late destruction of the Bassa and Panda countries, was brought upon them by Adama limself, according to their own statements. Usha, also called Afo and Ekpe, a part of the Bassas refused to pay tribute to Adama the king, and to punish them, he invited Ama Dogo, a war chief of the Filanis from Zaria, to attack them; an opportunity which was readily embraced by the lattcr. After the capture of the Ushas, according to the wishes of the ling, Ama Dogo picked a quarrel with Scnani the king's brother, who governed some portion of the Bassa country westward; and contrary to the king's wishes, they destroyed Akpatta, the town of Senani, and its dependencies; and as their avarice knew no bounds, Ihereku itself, the capital of Bassa, shared the same 
fate; and thus the country was overrun, till Panda was destroyed also. These particulars being related by the Galadima, the next in influence to the king, at the king's request, I could not help telling Adama that it would have been better for him to have lost the tribute of a few of his subjects than to seek their punishment by the hand of their common oppressors, and thus bring so much troutble upon himself, lis people, and neighbours; - that when a thief is employed to carry away a neighbour's goods, he will naturally seek opportunity to carry away those of his employer also; and that when an incendiary is engaged to set fire to a neighbour's house, we are not sure that our own will escape the conflagration. He felt the force of these parabolical expressions, and said nothing; but his subjects nodded assent to my remarks, and I doubt not, he regretted the foolish steps he had taken. The cireumstance of the king of Bassa inviting the Filanis to destroy Usha, which was the cause of the misfortune of Panda, explains the complaint of the Igbira or Panda people, that the Bassas had called the Filanis to destroy their country. Mr. May delivered the present from Dr. Baikie to the king, for which he gave a goat in return, and pleaded poverty.

We returned to the ship about ten $\Lambda$. .r., and immediately steam was ordered to be got up. $\Lambda$ t twelve A.M., we weighed for $\Lambda$ batsho; the place to which a remnant from Panda liad made their escape about eight months ago, according to thicir own reckoning. We arrived there in about two hours, 
and landed to visit Mahamma the chief, who we heard was out of health. Besides the village on the water-side, there was another about a mile inland where the chief resided, to which a most pleasant walk through beautiful plantations of Guinea corn led us. The extent to which the plantations had grown in so sliort a time, told the industrious habits of the Igbira or Panda people. It is very much to be regretted, that such a people who are ready to turn everything to account, and who, if called upon to raise produce for foreign markets, would turn their whole attention to supply it, should be at the mercy of those who will not labour with their own hands, and are bent on enslaving those who do. Although the chief was not well, and rose from his mat with great pain, yet he did so to offer us his bed for a seat, and shook us heartily by the hand with inexpressible joy at our safe returnfor news had reached this place also, that we had had a fearful battle with Filani warriors, and that there was great loss on botli sides. He and his people were glad to liear that the reverse was the truth. He offered us eatables, and Guinea corn, beer to drink, and yams for a present. Since we hare come among the Bassas and Igbiras, though they are oppressed, and driven to and fro by the Filanis, we may truly say we are among friends, and in the land of plenty. The country on the lack of the river where Abatsho is situated, is dry; and the soil contains some clay with which some of the huts are built. Some parcels of cotton were purchased by Dr. Baikie and Dr. Hutchinson 
for specimens, from the industrious women who employ their time in picking out the seeds, and spinning the wool into thread, to be sold to native weavers.

October 18: Started early this morning, and about eight A.M., anchored off Amaran, on the left side of the river, near Mount Pleasant. This village was not visited on our ascent. It also is inhabited by refugees from Panda. A regular market is kept liere every five days, and to-day being the market, we met a large concourse of people, both from the Confluence and upper parts of the Tsliadda. The arrival of the 'Pleiad,' of course, interrupted their market, and in a short time the ship was full of people. Here we learnt, with no small joy, that Mr. Crawford and his party were well, in the canoe at the Confluence. Aba, the chief, immediately came on board, and he and Dr. Baikie exchanged presents. We landed, and purchased wood, of which they had plenty, and many curiosities, which no doubt gave a profitable return to their owners. The busy scene before us was indescribably amusing. $\Lambda$ fter about two hours spent here, we weighed and visited the village of Oketta, on the right side a few miles below: liere we met the sister of Oyigu, the late king of Panda, who was killed by the Filanis. The island on which the people of Oketta liad taken refuge on our going up was completely overflowed, and the liuts thrown down or washed away. Their old villages, on a long strip of bauk between the river and a swamp, presented one complete scene of ruin and desola- 
tion; yet within the ruins the weaver was quietly pursuing his occupation, and the platter of mats his work. As the Filanis still hang about the country, it appears the ruins will be deserted altogether, and the inhabitants join their neighbours at Amaran, near Mount Pleasant. The poor old chief gave us some beer for a present. Starting from Oketta, we dropped anchor for a short time at Kende, where we made some stay at our ascent; a short visit was paid them, and we then weighed for Yimmaha, where we dropped anchor about three P.M. The island on which the people had taken refuge when we passed in August, was almost entirely covered, and they had returned to their town; the high grass and swollen waters not being favorable to the expeditions of the Filanis; the inhabitants thus enjoying a temporary security from these natural defences. The once, deserted shore of Yimmaha, where but four or five timid men were watching the movements of the Filanis, was to-day, lined by an immense crowd of men, women, and children. The hearty welcome with which we were received, could hardly be exceeded by that of our most intimate friends in a civilized country. We visited Ogara, the brother of the late unfortunate king of Panda, who is now elected in his room, and is at present residing at Yimmaha. Rumour had also disturbed this place from Rogankoto, with news of our fabled battle with the Filanis, at which they were not a little concerned. The statement of Ogara, the king of Panda corroborated that of Adama, the king of Bassa, respect- 
ing the invitation of the Filanis by Adama, to destroy Usha, which brought desolation upon them all. He said, the Filanis were now at war with Toto, that many of his people had only returned from that place yesterday, who went to ransom their children and relatives, and that some of the captives had effected their escape at the same time. As they had some ivory, the king requested us to return on board, that the people might sell it off.

October 19: After breakfast we paid a visit to the king, and entered more circumstantially into the affair of the destruction of Panda, and the state of things between him and the Filanis at present. He confirmed the statement that Panda was destroyed by treachery, and said, that Oyigu, the king, had entertained them as strangers or traders who had come to his eountry, but when a sufficient foree had got into the town, in the morning they commeneed eatching the people and plundering the houses. Three of the elders who had been eaught, but have sinee been ransomed, and who were sitting by Ogara, were pointed out to us. Madaki, an elder war elief, who owned some horses, was dreadfully wounded in several places, in the act of defending them, and three large gashes now on his liand and back must have been severe. Oyigu, the clief, was killed, and the inhabitants taken prisoners before they were aware that any hostility was intended against them; henee, all the dependent towns and villages were deserted, and the people fled for refuge to the island in the Tshadda, and to the other side of the river. Ama 
Dogo, the Filani war chief, offered the condition of paying one hundred slaves as an annual tribute; and the king said he feigned compliance with these terms, till he had recovered as many of his people from them as they were able to ransom; and that he would never go to Panda again, but when the dry season comes will remove to the other side of the river, and only inhabit Yimmaha in the rainy season, when it is difficult for the Filanis to get at them. He said, if they complied and paid one hundred slaves one year, in the next they would require two hundred, and where were they to get them? and that they detested war, trade being their chief employment. I asked him whcther, in case trade should be established with this country, he would like his people to bc taught God's book, and how to worship God as we do in the white man's country; for it was these two things together, which made England great, and that they would bring peace and prosperity to any country who received and embraced them. I told him that the same thing was proposed to the chiefs of Aboh, to the Atta of Igara, their sovereign, and to Mohamma, king of Hamaruwa, respecting the Baibai or Djuku people, and that they were all willing to trade, and that their people should be taught God's book: I wanted, therefore, to know what he would say to it also. He replicd that trade was their chief employment, and that he was very desirous that war should cease, that his people might trade, and be tanght God's book : he wished us many blessings and long life from the God whom we worship. He 
said that he was a trader himself, and had been to Hamaruwa, and that Mohamma, the present sultan, was his friend; he had been to Zhibu, and knew Bohari, the king, of whom he had a very low opinion, but spoke very highly of the Galadima, whose name he told us was Zumade, and that he was a worthy character. We confirmed his testimony from personal knowledge and experienee. Dr. Baikie asked what portion of the eaptives was now in the hands of the Filanis; he said, by far the larger portion, and that as long as the army kept togetler, and there was any prospeet of the eaptives being ransomed by their relatives, the Filanis would not sell them to others; but that would not be the ease when the army dispersed, and earried their eaptives to their different homes. Dr. Baikie enquired as to what might be the priee they paid for the ransom of each of their people; he replied, 80,000 eowries, whereupon the Doctor offered the king that amount to assist lim in the ransom of one person, for which the king did not know how to express gratitude enough in worls. He remembered Mr. Laird's visit to Panda, and asked whether he was still alive, when he was told that the same gentleman sent this ship to the river again. Having taken leave of the king, and got under weigh, about one P.Mr., we anchored, and visited the village of Ogba, on the top of Frenehwood cliff, which had been also deserted, but is now re-inha bited. We landed, and elimbed up the cliff. Kpanaki, the ehief, was not at lome, but we saw his sister, a woman of some eonsequenee, who is head 
of the village. As her brother, Kpanaki, was living in the village Okpangana, on the opposite side of the river, a messenger was sent to inform him of our arrival, and he returned with the chief's brother, with a message, that he regretted that he was not able to come to the ship, because one of his wives died last night. Some presents were sent to him by Dr. Baikie, with words of sympathy: and after about an hour's stay, we started from this place for the Confluence, and reached the east point of Duck Island about half-past six P.M., when the water began to shoal to two and a-half fathoms. Fearing we might run a-ground, or upon rocks now under water at the juncture, we dropped anchor for the night. 


\section{CHAPTER V.}

SICKNESS OF TWO OF THE PARTY LEFT AT THE CONFLUENCEEXCELLENT HEALTH OF THE EUROPEANS IN THE PLEIADDISSATISFACTION OF AMA-ABOKKO-DESIGN OF AMA AND DASABA TO BUILD A TOWN ON THE LAND PURCHASED BY THE BRITISH OOVERNMENT IN 1841-ZURI'S MISCONDUCT REPORTED TO AMA-FRIENDLINESS OF TILE NATIVES AND THEIR DESIRE FOR THE RE-ESTABLISHMENT OF THE MODEL FARM, AND TO BE TAUGHT OOD'S WORD-SYMBOLIC LETTER TO A NUPE IN SIERRA LEONE-WISH FOR TIE RETURN OF THE SIERRA LEONE PEOPLE TO THEIR COUNTRY-GROWINO POWER OF ABOKKO'S PARTY-IDDA-IISTORT OF THE RISE OF THE ATTAS-FEIENDLY RECEPTION AT ASABA-SUITABLENESS OF THAT PLACE AND OF ONITSHA FOR MISSIONARY STATIONSFANCY CLOTHS, \&C. AT ONITSHA MARKET-OSSAMARE-ABOH -INTERVIEW WITII AJE-HOSI'TTABLE TIEATMENT RRCEIVED BY SIMION JONAS-DESCRIPTION OF TIIE TOWN-CALL UPON THE CHURCI TO PREACH THE GOSPEL TIIERE-AGHEKUN'S VISIT TO THE TSHUKU-INTEIVIEW WITH TIIE CHIEF OF AOIAMA-RECROSSING THE BAR-ARRIVAL AT FEINANDO PO.

October 20: Started early and anchored off the town of Igbebe about seven A.M., in safety, where we were weleomed by the erew of the canoe which had left us nearly seren weeks ago. Their anchorage was very close to shore, and eonsequently, exposed to the filth and stagnant water in some pits, which rendered the place very unfarourable to health. From this or other eauses, Mr. Crawford was very unwell, and Mr. Gower, the second engineer, in a very precarious state of health, but all the natives were well. All the Europeans in 
the 'Pleiad' enjoyed what may be called excellent health in Africa, and I may, perhaps, say more so than is enjoyed for a length of time together on the coast. Since we commenced the ascent of the Tshadda, no one who had any thing to do on shore had been idle, either in communicating with the native chiefs, trading, or in prosecuting scientific researches; journeys were made, for instance, to Hamaruwa, a distance of fourteen miles inland, by a very bad road, and without conveyance, exposed to every inconvenience, without suffering in the least from these exertions. Our Krumen and the native crew from Sierra Leone have suffered from sickness up the Tshadda, but the cause could not be assigned to the climate; it was from want of proper food, and over exertion. Their blood, consequently, from want of adequate nourishment degenerated, and they began to swell from their feet, with pain and weakness in the joints; but no sooner was their diet changed, than they regained strength. It is a liundred and one days to-day since we entered the river, and no death has taken place in the Expedition. Not unto us, but unto God, we give praise and glory. At noon we landed to visit Ama-Abokko, and to thank him for his kindness in giving us the messengers who accompanied us up the river; but from the tone of Ama, it appeared Zuri had told him how kind Dr. Baikie had been to the king of Panda, though he had rendered us no service, and yet the Doctor gave him so many cowries; while Ama, who did everything in his power to 
aid us, was not half so well treated. Zuri had also falsely asserted, that we had paid the messengers one measure of cowries only. We explained the matter to the king, and promised to see him to-morrow with Zuri, that we might expose his bad conduct, which we would otherwise not have mentioned.

October 21: On our arrival here on Friday, I made enquiry after Dasaba, who was driven out of Lade, and about the state of the country in general. I was then privately informed that the Yoruba of Ibadan, in our station near Abbeokuta, were bringing Dasaba back to Lade; that the town was being put in order before Dasaba's entrance; that Ama-Abokko and Dasaba were friends; and that Dasaba had intimated to Ama-Abokko his wishes to come down the river, and establish a town on the land purchased by Government from the Atta in 1841, a portion of which was let for the Model Farm, from which place he would assist AnaAlokko against his enemies. I told Dr. Baikie what I laad heard, and suggested the expediency of reminding the king that the place is Government property, and that he is bound to take care of it for them, without alluding to what we lad heard. There was another matter comnected with Zuri, the messenger, for which we wanted an interview with the king. On our arrival at Ojogo, the ship anchored for a time to take him and Mahamma his companion on board, but it required no little patience and forbearance, as well as threats, to get him off: either some one was in 
his debt, or he owed something which he wanted to settle before he went on board. We threatened to leave him behind, and take Mahamma alone to the Confluence, in which case he would have to account for himself to Ama-Abokko, whenever he chose to return to him. In the hurry and confusion of getting them on board, as the ship had got under weigh, he brought his two sons, Musa and Bawalla, with him, and another little boy besides. He wanted four women, who he said had come from the king of Keana, to come on board and sell their rice, but we would not allow it, so the canoe was let go, and they returned to Ojogo. We knew Musa and little Bawalla to be his children, but the other little boy was quite a stranger to us, so we asked who he was, when he replied that he was a home-born slave belonging to Bawalla's mother, and as she had left lim to live with another husband, he took his son Bawalla away, and this little boy was his companion. IIad it been otherwise, Dr. Baikic would immediately have ransomed the slave boy; and as the three little boys were so happy together, we believed the matter to be as it was related to us, but I continued to watch if I could discover any cheat in the case. $\Lambda$ few days after this, Aliheli pressed Zuri to speak the truth as to whether the boy was really a slave intended to be sold away. The truth was thus elicited that he was purchased by Zuri for sale. Mahamma came to tell me the matter, and said, as we liad wished to ransom the boy, Zuri would let us have him. $\Lambda$ s they did this igno- 
rantly, I told Dr. Baikie of the fact, and the bargain was struek for the boy's ransom for 50,000 eowries. Among many other things, Zuri told AmaAbokko that he had purehased the little boy for him, and that Mahamma had taken the boy from him, and sold him to us. Early this morning Zuri eame on board to entice him away, but he was turned out of the ship, and told that he was fortunate not to be put in irons. After breakfast we went on shore, to have an interview with AmaAbokko on these various subjeets. I need not enter at length into the whole story; suffice it to say, that Zuri's miseonduet was related to the king, and Ama was given to understand that we bore with him for the king's sake, and henee alone he had not been dealt with as he deserved. The barefaced lie, that he and Mahamma had been paid only one measure of cowrics each, was alleged as an instance of his ill-behaviour; and he was forecd to confess before the king, that we had paid two measures to each of them. Zuri thought, by reporting the payment of one measure, he would keep the other entirely to himself, while the king would divide the reported one with him. I then told the king, that when a man was guilty of such duplieity to his own chief, he might believc that he would tell other falsehoods. I asked Zuri if he had ever mentioned to us that he had purchased the little boy for the king, and he confessed he had not. Dr. Baikie said he would keep his word, and ransom the boy; but instead of paying Zuri, he would pay the amount to the king 
himself. He was therefore liberated for 50,000 cowries, and is now very happy with us on board. Zuri had been very serviceable to us, but his character was sadly stained by his addiction to lying and covetousness. I took the Blue Book containing the papers of the Niger Expedition of 1841 with me when we went to the king. Ama was reminded of the visit of the four slips, and of the purcliase of the land for the Model Farm, together with the cause of its abandonment. He was then informed that Government had not forgotten the place; that we liad been to see it, and found it all right, and we requested, as he was close by, that he would keep an eye to it, and see that nobody touch the land, giving him to understand, that we should report at our return the condition in which we found it. Ama-Abokko replied, that he was now the owner of that place, and that it must be bought from him. I replied, that it was not customary to pay twice for one tobe (holding at the same time the tobe of Daganna his Galadima), upon which he smiled. Dr. Baikie told him that he would go over the ground, and put up a flag there before we returned to the sea, to indicate that the land is still a British possession. I pointed out to Dr. Baikie the necessity of taking such steps to keep Dasaba from occupying it, for once established there, he would do immense mischief to the poor defenceless refugees on the left side of the Niger, at the fall of the river. Moreover, if portions of land were once built upon, and the best localities spoiled by their irregular towns 
and villages, it would not be easy to clear it when the place should be wanted for better purposes. I regret that the Model Farm was broken up, though it could not have been otherwise under the circumstances on account of which it was abandoned. The natives are still looking forward to its re-establishment, more particularly for the purpose of traffic.

October 22: Sunday. Held service at halfpast ten A. M., and preached from 1 Sam. vii. 9-12. Truly we have much cause for raising our Ebenezer to God. All hands rested from labour, and no trade was allowed to be carried on with the ship, so the day wore the aspect of a Sabbath.

October 23, 24: The ship was full of people trading with all kinds of articles: ivory, country cloths, tobes, mats, shea butter, palm oil, yams, sheep, goats, fowls, \&c. Anything in demand, either for curiosity or for use, was readily brought for sale, for cowries, or in exchange for European articles. The scene showed the disposition of the people to trade, and that a trading establishment at the Confluence would prove beneficial to the country in general. The languages spoken here are Igara, Igbira, Nupe, Kakanda, Haussa, and Yoruba. The Yorubas find their way to the Confluence by way of Lade or Rabba, from Ilorin. People speaking Doma and Djuku, the language of Kororofa, also visit the markct at Igbebe at the Confluence, and the Ibo traders come up as far as this from the Delta. Among the things purchased as curiosities, was a kind of fancy clotl, said to be 
manufactured by the people of Igbo, south of Idda, near the Ibo country, who they said were like the Opú or Ibo, and their language nearly similar. Hence my attention was drawn to find out who the Igbos were.

October 25 : To-day being fixed for our departure from Igbebe, we went on shore to take leave of Ama-Abokko, and thank him for his kindness to us during our stay with him. The site of the Model Farm was particularly put under his care by Dr. Baikie, till steps be taken in due time to do something. I asked Ama-Abokko whether he would afford protection to any Nupe, Igbira, Kakanda, or Bassa people, who might be disposed to come over with the next Expedition, with the intention of settling in the country? He said there was plenty of room at Igbebe, and he would be glad to receive as many as were disposed to come; the only thing which caused him uneasiness was the unfriendliness between him and the Kakandas on the back of the town. We told him that we hoped when another ship came, and trade is opened, that those Kakandas would be spoken to, and that they would be friendly again. Ama-Abokko is quite willing that his people should be taught to read and pray to God, as we teach people of other countries. We shook hands with him, and parted with good feelings. Daganna, Ama-Abokko's Galadima, a Nupe by birth, is a worthy character. He professes Mohamedanism; and all the time the canoe was off the town, he paid every attention to it and its crew, that nothing might go wrong during our ab- 
sence up the Tshadda. Since our arrival, not. a day passed when we went on shore, that he did not invite us to his house, and entertain us with Guinea-corn beer, which he many times poured out of the pitcher for us with his own hands, though he would not drink it, being prohibited by his religion, nor, except for us, would he have touched it. This and other things, as kola nuts, he would set before us, or anything else he thought acceptable. He sent on board daily bowls of pounded yams, and a pot of good sauce, whic's was very much enjoyed by the ship's company. He was a business-like man, and very orderly in his manners, and obliging in his disposition. Ile was the last on board, and when sent on shore in the ship's boat, as we were getting under weigh, this young and affectionate man was seen shedding tears at parting with us, as if we had been old and intimate friends. All the people stood on shore, and followed the Pleiad with their eyes till she was out of sight. Onc of the sailors was the bearer of a symbolical letter to a Nupe relative in Sierra Leone. This letter consisted of a red parrot tail tied to a white cotton thread at one end, with a small picce of hard wood, burnt black at one extremity fastened to the other end of the thread, four cowrics being attached to the middlc of the thread, two facing each other, with the small ends upward, and the other two in like manner with the small ends downwards. 'This may be interpreted as follows:- the picce of hard wood burnt at one end may mean, we are well and strong, but 
have been mourning for your loss, and our hearts are as black as coal fire. The parrot tail may mean, we are all in good circumstanccs, and are expecting your return as soon as possible with the speed of a parrot. The pair of cowries with the small ends upward, facing each other, may mean, we wish to see you face to face. The inverted cowries may allude to the disorderly state of the country, as if all things have been upside down. These facts prove the willingness of the people for the return of their people, and their desire to enter into trade with the English; and with them before us, I hope some steps will be taken to aid the return of the natives of the Niger to their countries, as a beginning of future operations to improve the people. We anchored off the town of Agbedanma, situated on a hill, with Oko Odogbo below it on the left, and Otuturu on the right, on an island. Okeyin had removed his camp from English island to this place, on Abokko's people quitting the town of Idda, since we went up.

October 26: Dr. Hutchinson landed early this morning at $\Lambda$ gbclauma, where he met our old friend Ehemodina from Idda, and brought him on board; he said he had come there thirteen days ago on a visit to Okeyin, who was his relative, and he could not forget him though involved in a dispute witl a party, whom it appeared the $\Lambda$ tta favoured. He was invited to breakfast, but he would not eat before his people, or at lcast till he had performed some religious ceremony which he called washing; but although he was taken to the 
saloon where he might be by himself, yet he would not toueh anything. However, to oblige Dr. Baikie, after he laad touehed the wine in the glass with his finger, and rubbed it on his head and hands, he drank that:- the meat and bread intended for his breakfast he requested to be allowed to take home, and it was aeeordingly wrapped up for him in brown paper. His religious observanees gave opportunity for eonversation on the religion of white men, in whieh he engaged with mueh interest. Okeyin and his eom anions, who had also come on board, took breakfast in the saloon which they very mueh enjoyed. Okeyin being a brother of Ama- $\Lambda$ bokko, I related to him all that had been proposed about the return of the Igara, Igbira, Nupe, and Kakanda people, from Sierra Leone to this country, and he also promised, that if they eame, they should meet with a hearty weleome and full proteetion. Dr. Baikie then made them several presents, for whieh they were thankful. Abokko's people are a powerful party, as I have observed already under date of August 1.* They are becoming independent of the $\Lambda$ tta, and I believe in a short time, if the present disprite between them and Agabidoko is not soon settled, they will slake off his yoke. They eommand the market from $\Lambda$ boh to the Confluenee. Aje of $\Lambda$ boh seems to be in favour of Okeyin, and as they are commereial in their disposition, $\Lambda$ bol would go to trade with Abokko's people as far as the Confluence, were they to remove so far 11p

* Vide, page 27. 
the river. In eonsequenee of this, the old Ikiri market, (the Bocqua of the Lander's) is at present suspended, or rather removed partly to Igbebe, where Ama- $\Lambda$ bokko is now, and partly to Otuturu where Okeyin is eneamped. Aboh traders attend both markets, the latter espeeially, while the people from the npper parts of the river, stop either at Igbebe or Otuturu as they please; but Agabidoko's party dare not go up to either of them, nor disturb Aboh traders when passing Idda for Otuturu. It appeared from all aeeounts, that these two eontending parties are engaged in preparations for a confliet next month when the river falls. Time was allowed for the people to trade with us, and about noon we weighed for Idda, where we anehored in the afternoon, two guns being fired to announee our arrival. $\Lambda \mathrm{fter}$ five, we landed and walked along the edge of the cliff', but there is very little to interest a stranger. Many of the inhabitants having left the town, the houses were for the most part, empty; and long grass was growing between groups of huts whieh at one time were thiekly populated. It threatened a tornado and rain, but we managed to have a few minntes conversation with the brother of a chief before we hastened back to the ship, just as it was getting dark.

October 27: Early this moruing two messengers were sent to the $\Lambda$ tha to annonnce onr arrival, and to say that the whole day would be given to trade. No one felt any inclination to pay his majesty a second visit, on account of the diffieulty and waste of time, which made the task umplea- 
sant. The day was employed to better advantage on board, where people from different parts came together, and plenty of information could be collected. Our messengers did not make their appearance till late in the afternoon, when the Atta saw them, and promised the bullock offered on our ascent; but it was to be shot that evening lest he should get away by the morning. This made us doubt the sincerity of the $\Lambda$ tta, because the bullock could easily liave been secured till the morning. Since Abokko's people left Idda, there has been little or no trade in this place. The Atta however, wanted the ship to stop five days, to which we could not consent. The coals left near the water side by his permission and under his care three morths ago, were found safe, just as they lad been packed up by the engineer.

October 28: A man was early sent to the Atta on private business, and the bullock, still alive, was delivered to him to be taken on board, but without any assistance being given him. The animal made towards the man, and he at once let him go to escape being gored; and thus the Atta's present was lost-a loss which did not concern us much, as it was not given with a willing heart. We landed early, as steam was being got up, on a visit to a chief who was on board yesterday, and had a long conversation with him on different subjects. As far as he could recollect, he enumerated twenty Attas who reigned in Igara, and said that the present, who is the twentieth, is now in the twentieth year of his reign. He gave a brief 
account of the origin of the Atta, which is as follows:-The part of the country now known as Igara, was formerly Akpoto country, our informant being himself on the mother's side related to the Akpoto. The name of the original king was Igara; the first Atta came from the opposite shore from the interior, and belonged to a tribe named Ado, but called Idu by the people of Abol. His calling was that of a hunter, and whenever lie killed an elephant, or any otlicr beast, he never took any part for his own use, but delivered the whole to Igara the king. Igara at first suspected the proceedings of the Atta, but as lie did no misclief, and liad very little power; not muclı notice was taken of him. In the mean time, more people came orer from Ado and joined the Atta; and when he found limself sufficicutly powerful, lie refused to give Igara any more gane. Thereupon Igara demanded the leason of this; and the Attir gave an impertinent answer, that lie liad given lim enough already. A quarrel forthwith arose, and the Atta drove Igara into the interior, and became king of the Igara country. The $\Lambda$ kipotos we were informed, are now subject to the Atta, and their languagn is the same. The chief said, moreover, that the kings of Nupe and Abolı also sprung fiom $\Lambda$ do, as dicl the Atta of Igara. IIe also gave us information lespecting the natives towards the Ibo commtry, especially the Igbo, whom lie identified with the $\mathrm{O}_{\mathrm{pu}}$ or 1 1bo, which shall bo mentioned if the account be colroborited as we go down the river. Ile was rery glad to hear ne 
mention the intention of God's people to send their countrymen back from Sierra Leone to settle among them, and establish trade, and to teach them the worship of the true God as they have been taught in the white man's country. I spoke with him for a considerable time about God, and the folly of idolatry; and all I said was listened to by him, and all present, with much attention. We returned on board, and about halfpast eight A.Mr. left Idda, and anchored off Adamugu in the afternoon, where we landed. This was a town of some consequence at one time, where Abokko lived, and where Mr. Laird buried thirteen of the crew of the Quorra, and two of the Alburka. It has declined since the death of Abokko, and nothing but the association of its name with that man, and with Laird and Oldfield's expedition gives it any interest. On our approach, the few inhabitants armed themselves with muskets, ready for self-defence, and looked upon our landing with great suspicion; but there was a Haussa slave there with whom we spoke, and he quieted their fears. Dr. Hutchinson asked for the graves of the white men buried there some years ago, but it appeared no one there had any recollection of the circumstance. There was one man who said he remembered the visit of the white men, but he was a little boy at that time, so he could give us no account of it. Their chief they said had been dead sometime, and his son lad committed murder and ran away. Two among them were pointed out to us as their present chiefs, to whom Dr. 
Baikie gave some presents. The first town was flooded, and the stench of decayed vegetables was sensibly perceived. We wanted to get to their other town, but they told us we should have to wade before we reached it, so we gave up our intention. Dry-fire wood was asked for and readily brought; and thus a little trade was carried on with them. Some people had just come in their canoes from some inarkets on the opposite shore, with mats, said to be made by the people of Ado. This mat is of the same pattern used by the Yoruba, and the Ijebu near Benin, from which I think the district of Ado can be at no great distance. They gave us some account of the Igbo people, who they said were near the Opu or Ibo country, and very much like them.

October 29: Sunday. Held divine service at half-past ten, and preached from Heb. ii. 1-3. Some canoes came alongside to trade, but they were sent away, and told thit no business is done on this day, which is our Sabbath. 'There was a market to-day, in a place called Utò, about a mile below Adamigu, on the right side of the river. This market is said to be attended by the people of Ado, about a day's journcy from the interior; and Ara market, which is held at another time a few miles below, is attended by the same people. Both Utò and Ara markets were established by Abokko, when he resiled at Adanıugu, bnt he gave Ara market to Agabicko to reap the advantage of it for himself; hence Ara market belonged to old $A$ gabidoko, whose party is now residing partly at Idda, and partly in 
the neighbourhood of Adamugu, and is at enmity with Abokko's people.

October 30: As soon as steam was up, we weighed from $\Lambda$ damugu, and anchored off Asaba, on the right side, where we landed; the people as at other places, were frightened at first, and held themselves in readiness for self-defence, but a few words of friendship and peace soon subdued their fears. The town of Asaba is situated on a gradual elevation, and the road to the top from the water-side is kept in good order. Immediately before entering the town, a spacious road, which could not have been less than thirty feet wide, led into the place, and from this road others branched right and left under shady trees to private dwellings, in groups of family louses. The town is by no means regularly laid out, but this is more to its advantage, as the houses are at great distances one from the other, which makes it airy. The soil is a red mould, with which they build their mud walls, and the streets are covered with sand and loose earth. We were led to the house of Ezobogo, their head chief, for there are many. The reception we met with here was beyond expectation, especially as they bore a very bad name among their $\Lambda$ boh neighbours, for they are Ibos. Without entering into particulars of their willingness to trade, and to allow their people to be taught the religion of the true God, of which I spoke with them for a long time-the dryness, and probable salubriousness of this place, which opens to the Niger, and is the best port to the Ado country, which seems to border 
on Benin and Ijebu, make it the best ealeulated for a settlement of any I have yet seen between Aboli and Idda. The fine hilly eountry on the baek of Asaba, is called Oria, and belongs to Ado. There are two small towns between the hill and the river, whose market-places are Utò and Ara. The natives speak Ado, Ibo, and Igara. Some people from Ossamare reside at Oria, and are known there by the name of Akpram. There are some villages called Ugboru and Akpram, or Akpram Ugboru on the right side, belonging to Asaba; they paid tribute to the Atta formerly, but are now independent of him. Inam and Onitsha on the left side, and Asaba, used to be troublesome to $\Lambda$ bolı traders on the way to Igara, but could not prevent their going, beeause Inam is the only plaee which possesses eanoes large enough to make effectual opposition. There is also a small Ibo tribe on the left side, ealled Isugbe, before tributary to Obi, but now independent. A town called Asabutshi on the right, above Asaba, was first inhabited by a man who had murdered a man and woman, and fled thither for refuge. None of these places are visible from the river, but were pointed out to us near Walker Island, or the group of islands thereabouts. 'Their respeetive localities may be more aecurately determined hereafter. Among other places mentioned is the Igbuso distriet, at the back of Asaba, having two towns, Ogbori and Ogbobi. Uzugbe, Onitshi, and Utu on the left, belong to Idda. 'These are the names of different places between Adamugu and Onitsha, given to us by our interpreter. 
We weighed from Asaba, and anchored off Onitsha market, where we had seen about five hundred people in the market, on our ascent. Today was market-day, but we came too late, as it was just broken up. However, we met a few people, among whom was Odiri, the son of the king, or Obi Akazua, of Onitsha town, which was some miles from the market-place on the left side. Here we made enquiry for the Igbo tribe, who make the fancy country cloths, upon which Odiri at once pointed to himself, and said, "We are the people who make it." He told us, that the people of Idda, and higher up the river, not knowing the difference, call them all Igbo, which is the name of a small town named Igbo Inam; that their country is called Igbo, but in fact, they are all Elugu of Igbo, or Ibo, and that this is the market attended by the Elugu people from the interior. He then gave me the following names of towns in Elugu, which attend Onitsha market, held every five days : -Obotshi, Umu, Oja, Nkpò, Obba, Abadja Ezongauran, where the fancy cloths are made, Aloadja Obba, Akuku, Ukè, Oto, Nnewu, Ozhi-Owere, Obu, Ofu Abadja, Nkuere Nzlibe, Nteja. The names of the different fancy cloths are Owowo, Anaba Obiri, because made in Obiri, and Nwega. I asked Odiri, how they would like to see their countrymen now in white man's country, come back and reside among them, and teach them what they have learned during their sojourn in that country? He said, that as long as the white men have it in their mind to introduce trade, whoin- 
soever they propose to send, would be welcomed, and no injury would be done to any of their countrymen who might come to dwell among them. He asserted that they never sold one another, but such slaves only as are brought to them from the upper part of the country. He was very anxious that we should see his father; but we could not, as the town was some distance off, and we were desirous of getting to Akra-Atani that evening. Here we were told, that the tribe of Isuama make Ossamare their market-place on the river side. We left Onitsha market with the intention of anchoring off AkraAtani, where we missed Aje on our way up; but through the negligence of the interpreter, we passed the place before we were aware of it; we, therefore made for Ossamare, but could not reach it that evening, so we anchored off a placc called Osutshi, not visible from the river. I should have mentioned that the country at the back of Onitsha is dry, with rising ground, and this is said to be the character of the country far into the interior, with no water on the way. Asaba and Onitsha on the opposite shores present the two most promising localities to be inspected by those whose lot it may be to commence missionary operations among the Ibos. In questioning Aliheli, our interpreter, as to the dryness of the country in the interior, and whether the Elugu and Isuama have canoes; he answered, "They cannot swim :" meaning, they are not watermen, like the people of Ossamare, some of whose canocs are so sinall, that they sit across them, and strctch both their feet in the water, with 
which they propel the canoe, as if a duck were swimming in a pond.

October 31: Weighing early from Osutshi, we anchored off Ossamare, only a short distance from it, and went on shore. I was quite disappointed in this place, for it was a complete swamp. Although the river had fallen four feet, ard the town was partly drained, the spaces between the houses, and the squares within them were all mud, and the heavy rain of last night made it worse. Between the houses immediately facing the river, and the king's house, was a puddle or swamp, with about four feet of water, over which were thrown some pieces of broken canoes, and some sticks tied together in the shape of a bridge to cross to the king's housc. His square was more like a pigsty than the habitation of man; but the verandalis and rooms being raised above the level of the water were dry. We managed to get into the house of Nzedegu the king. After Dr. Baikic had told lim the object of his visit to the river, I was introduced to him as one having something different to propose. I told Nzedcgu the wishes and intention of good people in our country, to scnd their libcrated Ibo countrymen back to their country, to teach them what they had been taught in the white man's country, cspecially the knowledge of the true God whom we worship; that this proposal had been made to the chiefs of $\Lambda$ boh, the Atta of Igara, and other kings in the upper part of the country; and that they all agreed to receive their returning countrymen, and to permit their people to be 
taught by them the worship of the true God. He replied, that whatever the chiefs of Aboh, and the Atta of Igara, had consented to do, he would do also; besides this, that white men were their masters, and whatsoever they propose to them must be done. He said, the Isuama people attend Ossamare market, and that the country extends in the interior for many day's journey. After leaving the chief's house, I walked over the town, and looked into many of the houses, and found them all of the same character. When the water is high, canoes must be used in moving from one part of the town to another. Having seen the place, and heard the wishes of the chief, we returned to the ship, and weighed for Aboh, off which we anchored in the afternoon. I went on shore immediately in the same boat with Captain Taylor, Dr. Hutchinson, and Mr. Richards. We landed Aliheli, the Haussa interpreter, here. Aboh was found in the same state as Ossamare. Although the river had fallell four feet, our boat pulled within six yards of Aje's house, to which we had about five minutes' walk from the creek at our first landing, July 22. Large trading canoes were afloat opposite the houses in the cross streets; and as the water falls, the mud and puddle is left to be waded through by the people as they pass to and fro in the town. We managed, partly by skipping or tiptoeing over the mud to get into Aje's house, but some of the gentlemen had to be carried on neen's shoulders. Aje's house being built upon a mound above the level of the water, was compara- 
tively dry; but the square was very damp, and green algge covered some parts of it. Aje received us with much joy; and that we might enjoy our interview, unmolested by the crowd in the open but muddy inner square, he invited us into his private chamber, which had two or three pigeon holes as windows, to admit air and light. $\mathrm{He}$ desired us to sit down either on the mat he had spread for our accommodation, or, those who preferred it, on the chair and stool he lrought in. But this inner room was so dark that we could scarcely see one another's faces, and very close from so many sitting together, within so small a compass. We therefore preferred the noise in the open square to the smothering of the dark private closet; and went out again. I asked for Simon Jonas, who was then at Tshukuma's house, and he was inmediately sent for. After Captain Taylor and Dr. Hutchinson had done with trading business, I briefly introduced the subject of the contemplated missionary establishment among them, but deferred entering at length into particulars till I could see him and his brother Tsbukuma together. He said he knew all about it, and that all would be right. I then invited him on board to-morrow morning with his brother Tshukuma, according to the request of Dr. Baikic. We left Aje, and went on a risit to his younger brother Okoya, who, Simon Jonas said, was very kind to him, and expressed his wish many times to see me on my return from the Tshadda. IIe was very glad to see me, and entertained us with palm wine and kola nuts; 


\section{INTERVIEWS WITH AJE AND TTSHUKUMA.}

and I invited him with his brother on board tomorrow. Leaving Okoya, we paid a visit to Tshukuma who was very glad to see me again, and made anxious enquiries after the ship's crew. When I told him that we had all returned as we went, without losing a man, either by sickness or accident, he grasped me by the hand with repeated greeting, and said, "Your ship is a singular instance," and that we were more fortunate than all the vessels that ever visited this river. When I told him how far we had been, and that I had visited Hamaruwa, and spoken with the Filani king upon the subject of the white man's religion, and that he consented to let his people be taught,-Tshukuma was surprised, and looked upon me as if I had been to the end of the world. He asked, Did you see and speak with the king of the Filanis? I said, yes; and that Dr. Baikie had visited and spoken with him too, though it took us three days to go to lim from the water-side and back to the ship. Tshulsuma pointed to three little boys standing by, and said, the Filanis sold all these. I told him that he offered to present Dr. Baikie with two slaves, but they were refused, and he was told it was sinful to possess slaves. Tslıukuma could say no more, but listened to my brief relation of our visit to the countries up the river with perfect astonishment. Some traders had seen us at Rogankoto in September, and reported at Aboh that we had gone to the black waters, the country occupied by the Filanis, the disturbers of the world; hence their fear and apprehension for our safety. I invited him 
on board with Aje his brother, according to the request of Dr. Baikic. We left Aliheli on shore, and took Simon Jonas on board with us. Tshukuma requested that a boat should be sent for him to-morrow, which request I promised to make to Dr. Baikie.

November 1: After breakfast, the gig was sent for Tshukuma and Aje according to promise. The former came in the gig, but Aje came in state in his own large canoe, paddled by thirty pullaboys, with about thirty others, including eight or ten of their wives who accompanied their husbands on board. Tshukuma was dressed in plain white Turkey trousers, and a white English shirt and jacket, as when he visited the ship three months ago; but Aje appeared in superfine searlet Turkey trousers, and a scarlet serjeant's coat with a string of large pipe corals thrown over the collar. Both had red hats on their heads. Aje reminded me of his father, whom he resembled much both in dress and gait, and in his keenness as a trader.

After the usual salutations, Dr. Baikie had a long talk with them, after which I introduced the sulject of resident Clristian teachers. Tshukuma and Aje had consulted together on the matter previous to our arrival, and said that they were quite willing to receive them, but that the fault rested with us, for we had deceived them before in raising their expectation when their father was alive; and now they hesitated to believe till they see us fulfil our promise. I then explained the eause of the delay, but expressed my hope that it would not be 
long before our purpose was effeeted; telling them that it was on that account I had left Simon Jonas with them, that they might have time to think sufficiently on the matter. They said, Simon Jonas could bear testimony to their willingness, but the rest remains witl us.

During the three months Simon Jonas remained at Aboh, he was treated with a degree of lindness and respect, by Tshukuma and Aje, which quite exceeded our utmost expectations. He was taken ill two weeks after we left, and continued ill a weck. He was then in Tshukuma's house; he says that the eare and attention received fiom lim, was like that of a father. He was scut for by different chicfs in the town, for conversation, and to ascertain whetler what was said respecting our intention to form an establishment at $A$ boll, was likely to be earricd out. IIc often spoke to them about their superstitious praetices as being foolish, and onc of them, that of chewing a stick to clean the tecth, and then spitting before their country fishion, to invoke a blessing upon those who desired their good, imprecating lis anger upon those who desire their lnut, was given up by some upon lis representing to them the folly of so doing. Me found them teachable, inquisitive, and attentive to what was told them, and if proper attention were paid to them, much good might be done.

Simon Jonas mored about among them as a person of influence, from lis superior knowledge, and travelled a day's joumey inland to Okom Mla. $\Lambda$ this place he was asked by the chief, why we 
were going to remain at Aboh, and not with them also in Oko-Ala? Jonas could only tell him, that no place would be left unvisited in due time. He returned from Oko-Ala the third day fearing that the steamer might arrive in his absence. He then went to Asaba and Onitsha inarkets by water. These places are about the limit of the Aboh territory. He also visited Akra-Atani, Ossamare, Ogume, and Omu-Osai: in all which places he was well received. At Aboll, one little boy could say all the letters of the alphabet, others have learned some letters. Tshukuma had shown Simon Jonas a place near lis own abode, where he thouglit a house might be built for us, if I thought it suitable on my returu. He had examined the entire place according to my direction, and now left it to me to judge of the different localities for myself.

November 2: After breakfast I went on shore with Captain Taylor, and Dr. Hutchinson. Mr. Richards accompanied me, and we went first to Aje's house. While sitting in a private room, about 10 feet by 5 , which received light through six pigeonhole windows, as we were remarking about the length and breadth of the rooms, a petition came from two prisoners, through Simon Jollas, that we should intercede with Aje on their behalf. Being requested to mediate, I called the chiefs attention to the subject. I first proved the justice of rewarding the good, and punishing the evil; saying, that it was so in all parts of the world. After leaving the matter to work an impression upon his mind, I interceded for the prisoners, that they 
might be released for our sake. Aje was struck, he paused a little, spolse to one of his attendants, and then requested us to come to the square, where the prisoners had been bound, neck and feet, with chains, for the last twenty days. There he seated us, and requested me to repeat what $I$ had said to him in his private chamber. This I did in the hearing of those present, and of the prisoners themselves. Aje replied, in the presence of his people, that we were true people, that he would not refuse any thing we wished him to do; that if he was about to execute a person, and we were to tell him to forbear, he would do so; that if he was about to sell a person, and we should forbid it, he would desist, and that he would act now according to our request. He then immediately ordered the two prisoners to be set at liberty. As I had landed purposely to go through the town, I took Simon Jonas with me, and left Captain Taylor and Dr. Hutchinson with the clief, to talk about trading. I visited Tshukuma, had some conversation witl lim, and told lim that $I$ was going to walk through the whole of Abol. He said he apprehended some difficulty in doing so, on account of the mud and water in the cross streets, but I told him that I had come for the purpose and was determined to go through it. Tshukuma was very much in want of a chest to keep his clothes in. When Simon Jonas was here in 1841, he gave him one of lis,

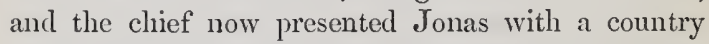
cloth, for whiçh he wanted a box in return; Simon could not spare the only one he had, and when I 
eame in, Tshukuma told me of Simon's refusal to aceept his present. Simon then explained the matter, and the chief pressed upon him the eloth or linen, which I told him to aecept. I wrote Tslıukuma's want of a box in my note book, and requested him to be patient till next year, when I hoped he would receive one. He offered to make me a present of a ram, which I requested him to keep till next year, please God, for the entertainment of my friends who might eome; and we took our leave. I next paid a visit to Isaba, an old man, whom I may eall the King's Counsellor. He is the keeper of the suits and other articles used when the ling goes through the eeremonial of being acknowledger as the sorereign of the nation. Since the death of the late Obi Osai, no one has been eleeted king in his stead, and Isaba has been aeting as the president of Aboh. All important matters are therefore referred to him for deeision, though Aje assumes the air of royalty, on account of lis wealth, influence, and power; and being an aetive and intelligent man, he is feared by the people. Isaba was very glad to see me, and asked whether Tshukuma had not mentioned his name to me; as he had not done so, I informed Isaba that Tshukuma had promised to tell all the head ehiefs what I had said to him, and observed that I did not doubt but that he, Isaba, was the prineipal person intended. The thought that he was not slighted pleased him; I then told Isaba that I harl heard of his great name, and eame to apprise him of our intention to send some Ibo teachers to Aboh, to reside there and teach the 
people God's book, and white man's fashion. He expressed his joy at the idea, and said that he had a female relation in Sierra Leone, whom he would be very glad to see at Aboh. This relative I afterwards understood to be the wife of J. Grant, one of the Ibo interpreters, who had visited Isaba the evening before. He entertained us with kola nuts. Leaving Isaba's house, I commenced my inspection of the town, from N.E. to S.W. it is fully a mile in length, and about 200 yards in breadth, lying parallel with the creek, with a wide opening along side the creek, the cross streets running nearly east and west. The greatest disadvantage to Aboh is the creeks formed up their streets at the rising of the river. The people themselves help much towards it, by digging clay in the streets, and in the front of their houses; and the holes admit water at every rise of the river. Thus what was before regular streets, are now notling but so many small creeks through the town. Moreover, they widen and deepen the streets, that canoes may be brought nearer their houses at ligh water. From these causes, the state of the long and cross streets was such that I should have had greater facility in my inspection had we been a week earlier, for I could have gone over the whole in a canoe paddled from house to house, but the river having fallen four feet already, nothing but mud remained, except where the water was deep enough for a canoe; and I had to wade through the streets. The sites of the houses, and the huge cotton-trees are undermined by the encroaching stream, though they still maintain their hold. But 
the fall of a tree would carry with it the ruin of many houses, and risk the life of their inmates. Other spots, sheltered by sacred groves and bushes, are not suffered to be cleansed, but left untouched, to be the receptacle of filth. This state of things served to show the real height of Aboh above the level of the water, before it was spoiled through the foolishness of the people. The south-west end of the town being but recently inhabited, has not yet suffered so much as the north-east; but the same plan of digging pits in the strects, and from the water's edge, is followed there also. At this end of the town, towards the entrance of the creek, within a short distance of the vessel's anchorage, in the main river, I have fixed upon a spot of land for a contemplated Mission establishment, and given Aje a strict charge not to suffer any of his people to meddle with the place, or allow the near neighbours to dig away the soil (which is in a great measure sandy), that no water may encroach and spoil that part also. Aje said, the land was his, and he would take care of it for us. I have taken this step to secure the spot at once, as bcing the best I could at the time discover. It will be left to those who may have to commence Missionary operations here, to use their own discretion when upon the spot. But after all that can be done, the place can only be occupied by native teachcrs. I cannot rccommend it for the residence of European Missionaries, though thcy may occasionally visit it from the upper and healthicr parts of the country.

Having proved the good-will of the chiefs and 
people, the respect they have for their countrymen who have enjoyed greater advantages than themselves, their willingness to be taught, and their anxious expectation to see us fulfil the promise long made to their late king in this respect-I cannot but conclude my report of Aboh by saying, I assuredly gather that the Lord hath called the Church to preach the Grospel to them.

In the evening, we shifted from our anchorage, and dropped a mile below Aboh into the open stream.

November 3: Weighed early this morning, and anchored off Agberi, the first Oru village below the Aboh district. Here we purchased fuel, of which the people had a large quantity for their own use, as they keep fires almost always burning in their houses, to dry them, and counteract the damp which proves so injurious to the inhabitants of the Delta. There were two headmen in the village, one an old man, called Igbemà, and the other a much younger person, called Agbekun. The latter visited our ship when aground above Truro island on the 18th of July. Since that time Agbekun has been absent at Arò, the capital of a district of that name near Isuama, where the Tshuku, the great god of the Ibos, resides. Agbekun, being childless, went thither to inquire of the god. While there, he went through many ceremonies, and performed many sacrifices; and had just returned with a favourable answer from Tshuku, whom, however, he himself did not see, because all communication with him must be carried on through the priests. He brought back some representations of guardian gods from Tshuku, three of which he 
showed us as a proof that he had truly been in the place of Tshuku. This is always reported to be at a distance of about three months' journey, though Agbekun performed it and back, with the performance of all the ceremonies, within that period. This gave me the opportunity of speaking to him about the true God, to whom I endeavoured to turn his attention to look for blessings, both temporal and spiritual. He wanted to know how to pray to the Great God, whom he knew to be greater than Tshuku. I told him to do so, just as a little child would ask his father for what he is in need of. Agbekun was very shy in speaking much about the Tshuku of the Ibos, as a great mystery is connected even with the place of his residence. Since his return, he has been going through some ceremonies, and cannot be seen or spoken to much in public, till the time allotted to them has expired, which will be in about two days. In consequence of this, he did not attend market; but he was told, that as we were from white man's country, his ceremony could not be spoiled by his conversation with us. He replied, "There is no hatred in white man's country as in black man's country." I told him to look at me, a Yoruba by birth; Simon Jonas, an Ibo; and Dr. Baikie, an Englishman; though of different nations, we live together as brethren, and so our God teaches all men to love one another. I expressed my hope that we should sonn be able to teach them this love, which he was glad to hear. When comparing Oru and Brass, or Itebu words together, his attention was called off to settle some mistake made about the pur- 
chase of wood outside. Dr. Baikie pointed out to me an Arò man, Okori by name, a blacksmith, who had lately come to Agberi with his son, with whom we had some conversation. He told us the names of some places of importance on the way to Arò, by the Bonny river, above $A b o h$; he knew the town of Simon Jonas, in Isuama, not far from Arò. At noon we weighed from Agberi, and anchored at the lower end of the branch explored by the Wilberforee, a mile or two above Angiama.*

November 4: We dropped down to Angiama to visit the ehief, as well as to purchase some wood. This place was completely swanped; how the people could live there I really could not eonceive. We were seated in an unfinished house, when Ndawa, the clief, made his appearance. He was the same person who requested that the ship should stop and trade on our aseent. Dr. Baikie gave lim a present of some red eloth as a kind of inducement to get lis people to sell wood, of which they had abundance, owned by the women, piled up in large heaps under their store liouses. These houses are ereeted upon sticks about four feet high from the ground, to avoid damp and moisture, and separate from their group of dwellings, to avoid fire, which may break out anong them. In a very short time, plenty of dry wood was bought for scissors, needles, snuff-boxes, and brass ferret-bells, with which they were exceedingly delighted. 'The chief invited Dr. Baikie on shore to lhis house, and presented him with a sheep, yams, and cocon-nuts. The Doetor impressed upon him the necessity of

* Sce Schön and Crowther's Journal, p. 38. 
maintaining friendship with white men, that trade might be carried on with him as well as with other chiefs in the interior and on the river. He then gave the chief a red serge cloak, which was very acceptable; and he promised to see that no molestation was offered to any boat or canoe belonging to us, which may go up or down the river. It will be re.membered that this was the place where MIr. Lander was mortally wounded. Having completed our business at Angiama, we weighed about nine A.Mr., and were once more in sight of the salt water at a quarter-past two P.M., dropping anchor about an hour after-just sixteen weeks, this very day, since leaving the spot.

Here again we have cause to raise our Ebenezer to God, wlio has led us out, and brought us in, in safety, both Europeans and Natives, without losing a single person either from sickness or accident.

November 5, Sunday: We lay at anchor, and preparations were made for crossing the bar on Monday. Mr. May, accompanied by Mr. Richards, left the ship early in the morning on a visit to Brass River, by the creek. They returned a little before sunset, but brought no news of any importance, neither letter nor newspaper. I held Divine service at half-past ten, and preached from Joshua xiv. 6 and 7. All the officers on board manifested an eamest desire to return thanks to the Lord, who has so mercifully dealt with us during our voyage up the river.

November 6: Steam was got up before daylight, and as soon as we could see sufficiently, taking advantage of high water, by seven o'clock, the 'Pleiad,' piloted by Mr. Richards, crossed the bar in smooth 
water, as if she was sailing in Clarence Cove. Here are again additional mercies, for which we cannot be thankful enough. About noon, the schooner 'Mary,' Captain Robertson, from Bonny, hove in sight. We came up to her, when Mr. Robertson boarded us, and brought a newspaper as late as August 19. He also gave us some news about the coast, and said that the mail steamer 'Ethiope' had left only about two days before. It was cheering, after four months' absence in the river, without communication with our friends, to hear news again of the civilized world.

November 7: Fernando Po was in sight this morning; and about five P.M. we dropped anchor in Clarence Cove, having been boarded by Mr. Mackenzie a short time before. We soon landed, and were received by Governor Lynslager, Rev. Mr. Diboll, the Baptist Missionary, and all the native settlers, with heartfelt gratitude that we all have been spared to return from the river in good health and spirits.

May this singular instance of God's favour and protection drive us nearer to the throne of grace, to humble ourselves before our God, whose instruments we are, and who can continue or dispense with our services, as it seems good to His unerring wisdom.

SAMUEL CROWTHER. 
APPENDIX. 



\section{APPENDIX I.}

'THE COUNTRIES ON THE BANKS OF THE NIGER AND BINUE,

\section{Abbeokuta, Jan. 1855.}

\section{Rev. AND DEAR Sir,}

I could not complete my notices of the comtries and languages on the banks of the Niger and Binue, in Central Africa, by the time I left the 'Bacchante,' which sailed for England last month, so I hope at this time to put you in possession of those notices, trusting they will be helpful in some respects in future researches in those countries.

You will be aware that the people we passed in our ascent are the Oru and $\Lambda$ bo in the Delta, the Igarra on the left of the Niger, the Kakanda at the Confluence of the Kowara and Tshadla, the Igbira, Bassa, Doma, Mitshi, and Djuku, otherwise called Apa, or Akpa, or Baibai, the language of Kororofa, and the Fulah on the Binuc.

1. The Oru, or Ijo, or Udṣo of Koelle are identical with Brass, at the mouth of the Nun, on the coast, otherwise called Itebu or Nempe, by their Ibo neighbours. This langrage is spoken to the extent of 100 miles from the mouth of the Nun, to the boundary of Abo territory: how far inland towards Benin, on the right and towards the Ibo country; on the left of the Niger, is yet nuknown.

2. The Abo is a dialect of the Jbo langnage, 
commencing from about the Benin branch of the Niger, and extending to Asaba (Onia market of Trotter). It comprises a district of about 50 or 60 miles along the banks of the Niger, and is very extensively spoken in its various dialects in the countries inland, on the left bank of the Niger, as far as we could ascertain, from the information we collected, to Cross River, on the back of Old Calabar; the Calabar or Efik and Bonny trade with the Ibo in the interior,-Isoama seems to be the leading or popular dialect of this language; all Ibo people who meet together in Sierra Leone, whether of the Abo, Elugu, Aro, or Abadja tribe, speak Isoama, and it has been recommended as the best to be used in the translations into the Ibo language: the Rev. J. F. Schön translated his vocabulary in this dialect. The Bonny or Okoloma, and New Calabar langiage is different from the Ibo, and from the fact that Bonny is principally peopled by Ibo slaves, and their continued intercourse with the Ibo of the interior, it may be inferred that in course of time, the Ibo language will gain advantage over the Bonny, which is very limited on the coast, when books are published in the Ibo language.

3. The next country after the Ibo, on the banks of the Niger is Igarra, the language of Igarra is the same as the Akpotto and is spoken from Adainugu to the Confluence of the Kowara and Tshadda, to the extent of 110 miles on the banks of the Niger. It is also extensively spoken inland on the left bank of the Niger, to the Mitshi country, on the left bank of the Binue-about the longitude of Ojogo. This 
language appears to be a mixture of Yoruba and the original Akpotto; its comparison with the Yoruba in the accompanying table will at onee shew their relationship.

4. The Kakanda is the next country on the banks of the Niger, and the language is a dialect of Yoruba. This people have been so mueh driven about, that the limits of their country are very diffcult to aseertain; they inhalited the mountains on the right side of the Kowara and border on Nupe : at present they inhabit chiefly the left banks of the Niger, below the Confluenee, since they were expelled from their mountain holds, by Dasaba, King of Nupe.

5. The next eountry after the Kakanda is Nupc, very much unsettled about the time of our visit. It has not therefore been explored.

6. From the Confluence on the right side of the Tshadda, is the Igbira country, called Koto by the Haussa, and Kotokori by the Yoruba; sinee their country has been overrun by the Felatas, they have removed to the left side of the river, in the eountry of Akpotto. Thcir language is different from Igarra. There is also a tribc of this peoplc called Igbira Hima, on the right side of the Niger between Idda and the Confluencc.

7. The next country after Igbira, on the right side of the Tshadda is Bassa, whose languagc appcars to be a distant dialect of the Nupc. 'Their country has also been ovcrun by the Felatas, and they were obliged to seek refuge in Akpotto land, after the example of their neighbours the Igbira. 
8. The next country on the right side of the Tshadda, is Doma, also called Arago, a tribe of which is called Agatu, inhabiting Akpotto land on the left side of the Tshadda, to which they had been driven by the Felani. I shall annex a comparative table of the language, as it also appears to me to be of the Yoruba class, if not Yoruba in its origin.

9. The next country on the left side of the Tshadda, is the Mitshi, whose language is very little known and very peculiar to itself. The Mitshi country commences as it appears opposite Ojogo, and is mixed with the Akpotto and with Kororofa from which it is difficult to distinguish the boundaries. They are chiefly independent, but some portion of them pay tribute to Wukari, King of Kororofa.

10. The next country after the Mitshi, is extensive,-Kororofa having, Wukari for its capital, and the language spoken is Djuku, commonly called Akpa, but they call themselves Baibai. The language is spoken as far as Hamaruwa, now under the government of Mohamma, the Felani Sultan of that country.

11. The next language we met with on the Binue, is the Felani.

12. The most important of all is the Haussa, the commercial language of Central Africa.*

From the above enumeration of languages, it will be seen that twelve distinct translations will be necessary to diffuse Christianity right and left on the banks of the Niger and Tshadda, and into

* For the extent of each country on the banks of the river, see the Map at the commencement of the volume. 
the interior as far as these languages are spoken; the same will be applicable in commercial intercourse with those nations: but there is a fact which has not been sufficiently noticed, that is, the facility whicl is given in communicating with these different nations on the banks of the Kowara and Binue, through the medium of the Haussa language, which is extensively spoken by the different tribes, with whom we had communication.

From Oru in the Delta, we already commenced meeting with solitary opportunities of communicating with the people, through Haussa slaves. From Abo we engaged an Haussa interpreter who was very serviceable to us throughout the Expedition. At Idda we found that the Haussa language was becoming more generally spoken by the inhabitants. Salutations in that language generally sounded in our ears. At Igbegbe near the Confluence, the Haussa is one of the prevailing languages spoken by the mixed population of that market town, and it is the chief medium of communication in commercial transactions, though Igbira is the language of the place.

At Yimaha in the Igbira country, at Oruko in the Bassa country, at Doma, also among the hitherto unknown Mitshis, among the inhabitants of extensive Kororofa, and with the Filanis of IIamaruwa, the Haussa language was the chief medium of communication, both with the cliefs and the people whom we visited during the late Expedition, and I was told that the knowledge of Haussa will bring any one to Mecca. From Igarra and upwards, though each language 
must ultimately be learnt, and translations be made into it, yet it appears to me, that a good translation into the Haussa language, for general use for travelling Missionaries among the nations above mentioned, will not fail to be of an invaluable advantage; this language seems to me, destined by God to be the general medium of imparting the knowledge of Christianity, to a very great extent among the nations by whom it is spoken, when we take the Haussa themselves of Kano, Katshina, Zanfara, and other tribes speaking that language as their own, into consideration: all the Mahommedans understand and speak the Haussa language, and through it the Koran is explained and interpreted in their mosques throughout Yoruba. So that from Lagos, Badagry, and Porto Novo, and upwards to the Niger, where Mahommedans are found, the Haussa language is spoken by them. Now, if we glance on the map, it will be at once seen to what extent this language is spoken, and its general usefulness in every respect.

From this circumstance, I may suggest that the reduction of the Haussa language is of very great importance, especially if there is any probability of an annual visit to the Niger and Binue by steam-vessels, for the purpose of commerce; and even if no attempt can yet be made to commence Missionary operations about the Confluence of the Kowara and Tshadda, such translations will be of general use among whatever tribes the travellers go. Schön's Vocabulary needs to be revised and improved. I shall be ready to contribute what I have now 
in possession towards such improrement when required.

Here I am led to remark the usefulness of Koelle's Polyglotta Africana. The languages above enumerated, except the Doma and Mitshi, ${ }^{*}$ were found among his specimens; and in those cases no time was wasted in attempting to correct lim, for these reasons-1st. It was sufficient to know he has got specimens of the language, constituting a good guide, and time would be lost in going over the same ground again. 2nd. The correction attempted might be useless, because one tribe may pronounce the same thing one way, and another another way, by changing letters; for instance-

$\begin{array}{ccc}\text { English. } & \text { Oru. } & \text { Brass or Itebu. } \\ \text { Water } & \text { Megi } & \text { Migi } \\ \text { Fire } & \text { Feni } & \text { Fendi }\end{array}$

among the Oru, and Brass, or Nempe. But additional words or phrases contributed to his few specimens, would tend to make the language better known. $3 \mathrm{rl}$. The time was too short to do it properly.

In looking over Mr. Koelle's collections, I could not help regretting that he has sometimes spent enormous labour in repeating, as many as twelve specimens, as under the head of Aku, what are merely variations in dialect and not of language; the seeming difference being no greater than that each tribe would pronounce the same word according to his peculiar tone or accent. The word would be commonly understood, it being no other language, - though sometimes different words are given; but

* See note, p. 234. 
these are not many. I could increase the dialects of the Yoruba tongue to twice that number, and yet two translations are not necessary among them. The same remark is applicable to Mr. Koelle's two specimens, under Haussa of Kano, and Katshina; and his five specimens of Ibo, under Isoama,-the change of $r$ for $l$, or for $n, s$ for $s h$, is very common, and constitutes in many cases the chief difference of a tribe. The people from different tribes meeting to transact their usual business do not take much notice of their difference in this respect, so long as they can understand one another; therefore, their being written as specimens, beyond enumeration of the tribes under a certain head, seems to be unnecessary. But the work is a valuable production, and of great utility to a great distance in Western Central Africa.*

There are three places which go by the name of Ado about this part of the country. One is south of Otta, twenty miles north of Badagry; one is not far from Isehin, in the Yoruba country; one is between Benin and Abo, inland, on the right side of the Niger, opposite Adamugu. This last Ado appears to be not far from Ijesa country, near Ife, and among the following group of tribes of Yoruba dialects ; viz.: Ijamọ, 'Éfọ, Ondo, Idoko, Igbomna, Ife, Ijẹsa, Ado. This last is the Ado mistaken for the one near Badagry by Mr. Koelle, consequently the position of his Ijeșa in that place is wrong; the situation of Ijeșa near Ifẹ, north of Ijẹbu, will be more correct.

* The Map accompanying this volume will correct, in some measure, Mr. Koclle's positions of those countries visited by the Expedition. 
Isoama, in the Ibo country, is on the left side of the Niger, north of Aro, and not on the right, as Mr. Koelle was informed, but an accurate knowledge of these places can only be obtained by further researches.

I cannot bring these notices to a close without again pressing the necessity of immediate steps being taken, when another Expedition ascends the river, to locate some persons of the Ibo nation in the town of Abo, and, if possible, also sorne Christian teachers at the Confluence of the Kowara and Tshadda; the latter is a nucleus of trade between the natives of the interior, and the situation most important. When two or three yearly visits in succession are made by steam-ships, there will be mutual understanding between England and the inhabitants of the Delta, the river will be opencd for our boats and canoes, as the Ogun is at present with us in Abbcokuta. It is my belief, and I do not express it from a momentary excitement, that the Niger Mission may yearly be visited by prudent and experienced Missionaries from the Yoruba country. It only requires that seasonable opportunity be seized to open the way, and keep a chain of communication between this and the Nigcr, so that in case there is no opportunity of visiting it by steam from the sea, the Mission will not be neglected, when it can be visited by the land route. 


\section{APPENDIX II.}

\section{COMPARISON OF LANGUAGES.}

\section{English.}

A large thing

A small thing

White book

Black book

Black man

This thing is good

A bad person

Old cloth

Old man

A young man

I am sick

I am well

It is hot

I am cold

The cloth is wet

My cloth is dry
Thisperson is greedy Enni pari A stupid person

A rich person

A poor person

A straight stick

A crooked stick

Énni dàda

Enni ale
Igarra.*

Nhun yi nanna

Nhun yi yan

Takarda funfun

Takarda dudu

Enia dudu

Nhun yi yọ̀n

$\left\{\begin{array}{c}\text { Enni ibi (evil } \\ \text { of Yoruba) }\end{array}\right.$

Igbo ìpo

Onia anagbo

Onia kolobia

Oggá mu mii

Ogá mi tan

$\left\{\begin{array}{l}\text { Emi jo (jo, to bum, } \\ \text { is used) }\end{array}\right\}$

Afun apa mi

'Ipo yi ț̣omi

'Ipo mi gbe

Enni etșe nulıun
Yoruba.

Ohun yi nila

Ohun yi kere

Takarda funfun

Takarda dudu

Enia dudu

Ohun yi dara

\} Enia or Enni buburu

Aṣo gbigho

Enia arugbo

Ommo kọnri enia

Arọn mu mi

Aron mi tan

Omi gbona

Otutu mu mi

Aș̣ yi tutu

Așo mi gbe

Enni yi lawọn

Enia gigọ̀

$\{$ Enni ti o șolohun,

$\left\{\begin{array}{c}\text { or olowo } \\ \text { En }\end{array}\right.$

Ẹni oluponju

$\left\{\begin{array}{c}\text { Ori ki bò̀ro, Nle } \\ \text { yanja }\end{array}\right\}$ Iggi titọ

* See my remarks on this language in my Journal of the Expedition, 1854, p. 355 . 
English.

Governor of a province, entitled King

Medicine

Face

Nose

Ear

Mouth

Tooth
Igarra. Yoruba.

Olu

Ogun

Iwaju

Imo

Eti

Ennu

Eyin or Ehin

But other words are entirely distinct, as in

Blood

Small Pox
Ebia

Oyasuma
Eje

Sanpanna, \&c.
English.

Ear-ring

Fire

Axe

Sun

Dry scason

Thread, cotton

Rope

Tree

Walking-stick

Yam
Doma.

Oruka

$\left\{\begin{array}{c}\text { Olá, from Yoruba, } \\ \text { lá, to lick }\end{array}\right\}$ Ina

Akeke

Eno

Ono

Owu

Ongua

Akeke or Ã ke

Orùn

Erùn

Owu

Okun

Yoruba.

$\left\{\begin{array}{r}\text { Olpa, Opa, Yoruba } \\ \text { word for a stick }\end{array}\right\}$ Iggi

Okute, Okaje, from

$\left\{\begin{array}{l}\text { Yoruba, Elcute, } \\ \text { post }\end{array}\right\}$ Opa

Iṣi

Isu 
English.

Onion

Horse

Milk

Egg

Musquito

House

Leopard

Chameleon

Frog

White man

Young
Doma.

Alibosa

Alubọsa

Yoruba.

$\left\{\begin{array}{l}\text { Oyan, from Yoruba } \\ \text { Yan, to neigh, to } \\ \text { gape }\end{array}\right\}$ Essin

Omu

Ayi

$\{$ Emia, from Yoruba

Eyin

Ille Ole

$\left\{\begin{array}{l}\text { E.je, from Toruba } J e,, \\ \text { to eat }\end{array}\right\}$ Ekùn

$\left\{\right.$ Oyan yan, from $\mathrm{Yo}_{-}^{-}$?

$\left\{\begin{array}{l}\text { ruba, Yan, to walls } \\ \text { leisurely }\end{array}\right\}$ Agẹmo

$\left\{\begin{array}{c}\text { Okiritu, from Yoruba, } \\ \text { Kirifo, a leaping, } \\ \text { roving about }\end{array}\right\}$ Opollọ

Oyibo

Opepe
Oyibo

Opepe, a young person

2. PERSONAL PRONOUNS.

I

\section{Thou}

$\mathrm{He}$, she, it

$\mathrm{We}$

You

They

Ami, Na, Ni, Nga, M. N. Emi, Mo, Mọ, Ng Awọ, $\mathrm{O}$

Anu

Awa

À ni

Alọ
Iwo, 0

On

Awa

Enyin

Awọn 
English.

Doma.

Yoruba.

We three sit down Awa sẹtta awa Awa mẹtta awa joko ayaje

You three sit down Ani sẹtta ani ayaje Enyin mẹtta enyin joko

'They three sit down Alo setta alo ayaje Awọ mẹtta awon joko

3. REFLECTIVE PRONOUNS.

I myself

Thou thyself

He himself

We ourselves

They themselves
Amu amu obohin Emiti karami

Oyi iwo ne Iwọti karare

Ase ni abohinu Onti kararẹ̀

Awo bokiwo

Awati karawa

Alọ bọkigalo

Awọnti karawọn

Some words are borrowed from the Haussa.

\section{English.}

Book

Ink

Rice

Ram

Lead

Chain for neek

Drum
Doma.

Takarda

$\left\{\begin{array}{c}\text { Orubutu,from } R u- \\ \text { butu, to write }\end{array}\right\}$ Tadawà

Sinkafa

Rago

Aderema

Așirika

Okanga
Haussa.

Takarda

Sinkafa

Rago

Darima

Sarakà

Ganga

From the above eomparison, it will be seen that the Doma appears to be a kindred language to the Yoruba, botlı from the formative prefix, construction of sentences, and by a eareful trace of many of its words, which seem to have Yoruba roots and ideas for its origin: when the language is properly reduced, it will not unlikely be found 
to partake of Yoruba, and other neighbouring languages, with which it has become mixed in course of time, like that of the Igarra and Akpotto.

4. COMPARISON OF THE LANGUAGES OF THE DELTA.

\begin{tabular}{llll} 
English. & \multicolumn{1}{c}{ Oru or Ijo. } & $\begin{array}{c}\text { Brass, Itẹbu } \\
\text { or Nempe. }\end{array}$ & \multicolumn{1}{c}{ Bonny. } \\
Water & Megi & Migi & Mingi \\
Fire & Fini & Fendi & Fene \\
Firewood & Fendia & Fingia & \\
Mat & Ute & Ute & Bile \\
House & Wale & Wale & Wari \\
Idol & Owu & Owu & Juju \\
God & Orișa & Orișa & Tamọnọ*
\end{tabular}

\section{TERMINOLOGY FROM KING PEPPEL.}

Bonny is called Okoloma by themselves,

" Okoloba, Obani, or Ibani, by the Ibos.

" Osiminiku by Abo tribe of Ibo.

New Calabar is called Bom by the Ibo.

King Peppel said that Bonny was chiefly peopled by Ibo slaves, though they speak the Okoloma or Bonny language, which is also the language of New Calabar.

I remain, Rev, and Dear Sir,

Your obedient humble servant, SAMuel Crowther.

* This name, Peppel king of Bonny, told me is applicable to the true God, others more to country fashion. 


\section{TRANSLATIONS.}

\begin{tabular}{|c|c|c|}
\hline English. & Doma or Arago. & Mitshi. \\
\hline One & Oye & Mom \\
\hline Two & Onpa & Hari \\
\hline Three & Metta & Tara \\
\hline Four & Mẹnni & Yin \\
\hline Five & Meho & 'Tan \\
\hline Six & Mihiri & Karmọ \\
\hline Seven & Mohapa & Karhari \\
\hline Eight & Mohata & Kartar \\
\hline Nine & Mohani & Karyin \\
\hline Ten & Iguo & Pue \\
\hline Eleven & Iguo-roye & Puẹ karmon \\
\hline Twelve & Iguo-epà & Pue karhari \\
\hline Thirteen & Iguo-ẹtta & Pue kartari \\
\hline Fourteen & Iguo-ẹnni & Pue karyin \\
\hline Fifteen & Iguo-eho & Puẹ kartan \\
\hline Sixteen & Iguo-ihiri & Pue tartan \\
\hline Seventeen & Iguo-apapa & Pue tankartan \\
\hline Eighteen & Iguo-ahatan & Pue yinyin \\
\hline Nineteen & Iguo-ahanni & Pue kartarkaryin \\
\hline Twenty & Iniye-gase & Kundu \\
\hline Man & Osẹ & Numguso \\
\hline Woman & Gboyin-ole & Kuasa \\
\hline Boy & & Wána \\
\hline Girl & & Guana \\
\hline Father & Ada & \\
\hline Mother & Enim & \\
\hline
\end{tabular}

* The Haussa being the medium of collection, $s h$ has been retained to avoid two different modes of spelling. 
English. Doma or Arago. Mitshi. Grandfather Osumoka

Grandmother Obohun

Son

Daughter

Oyimeme

Elder Brother Osum

Younger Brother Okinahin

Elder Sister Onume

Younger Sister Okinahin

Friend

Oya

Kará

Stranger

King

Oga

Male Slave

Osse

Female Slave

Ofie neyunro

Doctor

Medicine

Ofie niyan

Oboshi

Eshi

Head

Eyin

Hair

Eyin-ehuे

Face

Forehead

Nose

Eye

Ear

Mouth

Tooth

Tongue

Throat

Gullet

Neck

Shoulder

Arm

Ogú

Ogoyanma

Ewun

Iyepù

Apalıa

Okonu

Ahunnu

Enne

Ario-ogoyin

Worobanya

Ntshowo

Itshe

Ishigi

Itshuru

Shami

Eshie

Ato

Ijua

Ayin

Nomburo

'Olko

Atshobo

Abo

Arm, between

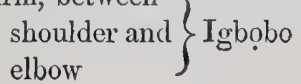


English.

Arm, between elbow) and wrist

\section{Leg}

Outer hand, or hand

Inner hand

Foot, or instep of the foot

Foot sole

Finger

Toe

Elbow

Rib

Chest

Female breast

Belly

Navel

Thigh

Knee

Heel

Nail of finger or toe

Skin

Bone

Vein

Blood

Itch

Small Pox

Hat

Cap

Shoe

Shirt

Trousers
Doma or Arago. Mitshi.

Mugabo

Ikpo

Abọn

Akpugabo

Ikpo

Ipugikpo

Abo

Okubikpo

Okekebobobo

Akoro

Otu

Ame

Ipu

Ondo

Atọku

Okukù

Ikpokitipi

Ekugabo

Okpakipie

Kpoku

Oyi

Ekke

Eleyanku

Akata

Otingira

Okpa

Togbo

Owirikí 
English. Doma or Arago. Nitshi.

Waistcloth Akiri, Zanua Kondo

Town (village) Oja, Oja yan ku

Market

House

Door

Doorway

Bed

Mat

Knife

Spoon

Ear-ring

Armlet, Bracelet ` Oje

Pot

Ẽi

Calabash, (large) Obatu

Calabash, (small) Ogo

Gun

Powder

Sword

Spear

Bow

Arrow

Quiver

War

God

Devil

Idol

Greegree

Sacrifice

Heaven (sky)

Hell
Kazua, kasua

Yobo

Thó

\{ Hima (Iron ring to draw the bow)

Kerifi

Tiage

Kapu

Burka

Ishomo

Iwanga

Ada

Bana

Gbanda

Tiaba

Wòndo 


\begin{tabular}{|c|c|c|}
\hline Fire ${ }^{\text {English. }}$ & $\begin{array}{l}\text { Doma, or Arago } \\
\text { Olá }\end{array}$ & $\begin{array}{l}\text { Mitshi. } \\
\text { Wusu }\end{array}$ \\
\hline Water & Eyin & Ngoromi \\
\hline Soup ' & Ibobo & \\
\hline $\begin{array}{c}\text { Meat (often } \\
\text { animal) }\end{array}$ & Ebẹ & \\
\hline Salt & Omua & \\
\hline Gold & Ozanaria & \\
\hline Iron & Oje, nofi & Akara \\
\hline Stone & Ego . & \\
\hline Hoe & Fnu & \\
\hline Axe & Akeke & \\
\hline Book & Takarda & \\
\hline Ink & Orubutu & \\
\hline Sun & Eno & \\
\hline Moon (full) & Ọa & \\
\hline New Moon & Oya fufe & \\
\hline Day & Eno & \\
\hline Night & Otu & \\
\hline Dry season & Onọ & \\
\hline Rainy season & Ogua & \\
\hline Rain & Oso, or uso & \\
\hline Dew & Omẹ & \\
\hline Coal & Ubi & \\
\hline Smoke & Iwola & \\
\hline Soap & Ukọ̀ & \\
\hline Sand & Oje & \\
\hline Canoe & Owu, & Igbanda \\
\hline Ship & Owugeibo & \\
\hline Bench, chair & Okka & \\
\hline Needle & Oyina & \\
\hline Thread & Owu & \\
\hline
\end{tabular}


English.

Rope

Chain, fetters for the feet and neck

Drum

Tree

Fire-wood

Walking-stick

Leaf

Root

Palm-tree

Palm-oil

Guinea-corn,
Doma.

Ongua

Ashirika, for the hand ; Eyeotikpo, for the feet

Okanga

Okpa

Efu-kola

Okute-okaje

Epu

Egba ko kposhi

Mitshi. 
APPENDIX II.

English.

Onion

Maize

Beans

Farm

Forest

Horse

Mare

Cow

Bull

Milk (fresh and) sour)

Butter (fresh and melted) $\}$

Sheep, ewe

Ram

Goat

Buck

Cat

Rat

Pig

Bat

Pigeon

Parrot

Fowl (hen)

Cock

Egg

Bird

Fish

Serpent

Scorpion
Doma.

Alibosa

Ibakpa

Eze

Eho

Okpá

Oyan

Oyan-leyan

Enna

Énna-neyinro
Mitshi.

Ame

Anangoyi

Adogbo

Rago, tukpo $\quad\left\{\begin{array}{l}\text { Lumu, or } \\ \text { Numu Yimgo }\end{array}\right.$

Ikpowu

Keme kusa

Bantshakù

Igú

Orushu

Ariga

Mandegu

Okò

Ogu, ugu

Obugu

Ayi-ogu

Igbanọ̣

Ebe

Eguwa

Enna 
220

English.

Musquito

Butterfly

Spider

Wasp

Bee

Honey

Lion

Leopard

Elephant

Ivory

Alligator

Monkey

Chameleon

Lizard(common) Apùwa

Iizard (large red-headed) $\}$ Oyinkpaku

Toad

Frog

Dog

Great, large

Little, small

White

Black

White man

Black man (negro)

Good

$\mathrm{Bad}$

Old (of things $\}$ Osẹke
Akirifù

Iwo

Yanko, yanku

Leke

Onehe

Nobi

Oyinẹe, oyibo

\} (se-nobi

Oshi, ososhi

Olabi
Mitshi.

Emia

Eho-ayikẹọ

Eho

'Idu

Eje

Adagba

Ahunnu

Ikù

'Eka

Oyanyan

Shie, ivory ring and persons) 


\begin{tabular}{ll}
$\quad$ English. & \multicolumn{1}{c}{ Domo. } \\
New (Young) & Opẹpe \\
Sick & Agbere \\
Well & Eshi \\
Hot & Akola \\
Cold & Soshia \\
Wet & Ngeyin \\
Dry & Oyinmọwe \\
Greedy & \\
Stupid & \\
Rich & \\
Poor & Oneta \\
Straight & Ntokoka \\
Crooked (bent) & Agahún \\
I go & Mu o we \\
I come & Na yin yàn \\
I run & Yinyan, ngan ikoyaje \\
I stop & Nga iyàje \\
I sit down & Ngbotá ngbore \\
I lie down & Na showu \\
I breathe & Na kọo \\
I cough & Na tashushu \\
I sneeze & Na aholá \\
I snore & Na ayeyẹ \\
I laugh & Ami shiku \\
I weep & Nga kwajè \\
I kneel & Nẹna \\
I dream & Agbolá \\
I slcep & Oge ku \\
I die & Ngo nu \\
I fall & Ni só \\
I rise &
\end{tabular}


English.

I speak

I hear

I beg

I bathe or wash myself

I see

I take

I buy

I sell

I love thee

$I$ give thee

I eat yam

I drink water

I cook meat

I kill a fowl

I cut a tree

I flog a child

I catch a fish

I break a stick

I call a slave

I cover a pot

I sew a shirt or cloth

I pray to God (beg God)

I play

I do not play $\left\{\begin{array}{c}\text { Nshiga nu, Onọ } \\ \text { ga-shiga }\end{array}\right.$

$I$ dance

I do not dance Yesterday
Doma.

Mpó

Giam

Ngaye

Mmá

Na ibise

Nga rosa, ni ma ni

Ni ira

$\mathrm{Na}$ doka ho

Ni zo ho

Na ri ishi

$\mathrm{Na}$ goyin

Ebe isola

Na mo oga

Nga she kposhi

$\mathrm{Na}$ go ize

Nga ngbebe

Lefi ki ngbo

Na yi oga ofie

$\mathrm{Na}$ le yi isola.

$\mathrm{Na}$ goza ; Na ga kiri

Na bu Oso

Nga shiga

Nga gige

Ngige na

Enne
Ma ke lá

Mitshi. 
English.

To-day

To-morrow

Cowry

Bowl

Lead

Brass

Stars

Bead

Shea-butter

Iron hoe, metal currency

Red

Bowl of a pipe

Pipe

Brass ring

Flint

Paddle

Post

Canoe men

Farmer

Fishermen

Trade

Trader

Judge

Poison for arrow Antidote topoisoned arrow

Hunter

My father
Doma.

Nkeni

Oki

Ekuri

Okpara

Aderema

Oje

Eyinyin-Ọwo

Eke

Anaza

Akika

Bẹ̀rẹtete

Tukunia

Turi

Miki

Ibia

Dodo (red cloth)

Etshu

Puẹni

Nnaha

Ikono

Mitshi.

Osene powa 
English.

My mother.

My grandfather

My grandmother

My stranger

My wife

Black shoe

Good morning

I hope you rise well ?

Do you hear?

I hear

Leave it

A woman spins cotton

Cock crows

Egg breaks

Bird flies

Fish swims

Snake bites

Honey is sweet

Bee stings

Lion roars

Ivory is heavy

Monkey skips

Dog barks

Sheep bleats

Goat runs

Pig squeaks

Rat burrows
Doma.

Oyam

Onkuọm

Amoyam

Ozoga

Otshim

Okpa lobi, Takalmi nobi

Ogà

$\{$ Gbeshi nĩ, or Gbe shi

gege nĩ ?

Opo nĩ?

Mpo we

Shabatá

$\left\{\begin{array}{l}\text { Oya jowu, or Gboyin ole } \\ \text { jowu }\end{array}\right.$

Ogu tọnu

Ayigu guitshia

Igbano yinso

Ebe tige iyowon

Ego (Eguwa) fohunnu

Eho loyan

Elọ isum

'Idu shiku

Ahìn gaba gbenu

-'Eka shobi

Ewo (Iwo) wonu

Adogbo degbà

Ipowu Oyinyon

Orushu deghama

Iyu yọ le 
English.

Alligator bites

I buy an ivory

A large cloth

A small cloth

White paper

Old house

New house

Hot water

Cold water

Small cloth is wet

Large cloth is wet

Small cloth is dry

A straight stick

A crooked stick

This slave

You call me

I call a boy

A boy calls me

A red cap

A very ligh tree

I fall badly

Very much

The tree is very large

The glass is very dazzling

This paper is very white This gun is very black The bird flies very high
Doma.

\{ Ikn fosahunnu, or fahunnu

Nahin gaba ni la

Ekpa yankó

Ekpa leke

Takarda onehe

Oda osonẹke

Ọle pepe

Iyọnlâ, akola

Eyin shoshia

Akiri ngeyin

Okpa ngeyin

Akiri oyimowe

Kposhi oneta

Kposhi ntokoka

Ofiè ni

Ami yo gurà

Oyi keke

Oya ku yọ igú

Tingira nọwa (yoyo)

\{ Kposhi nyanka goga,

Kposhi owiripo goga

Ngonu gburo

A goga, agngagnga

Kposhi o jaku goga

Ozomibe o mbe wàyawaya

Takarda ọsehe gbogbo

Bindiga o lobi wiri

Igbana o gizo gbogho 
English.

The water is very full The wind blows very strong to-day

The night is very dark

I eat in a bowl

I cut with a knife

I drink water

I am thirsty

I myself

Thou myself

He himself

We ourselves

You yourselves

They themselves

Who?

Whose?

Which?

What?

'This?

That?

What are you thinking of?
Doma.

Eyin lopajẹ gua yànyan

Ohu ta gogagoga nkeni

Otu nkeni ệbe dobugo gagoga

Nlone ebe okpara

Lokoshe ti kewà

Ngoyin

Egin aw om

Amu-amu obohin

Oyi íwo nẹ

Ase ni abohinnu

Awọ bo kiwo

Alọ bo kigalọ

Onò koni ?

Ọo kò gbo da ni ?

Onò ko anú?

Wu ka la ni ?

Onẽ ?

Olam nẽ?

Ozhi ni oyi nẹ nè? 
7. PERSONAL PRONOUNS.

English.

1. I

2. Thou

3. He, she, it

1. We

2. You

3. They

1. I eat

2. Thou eatest

3. He eats

1. We eat

2. You eat

3. They eat

We three sit down

You three sit down

They three set down
Doma.

Singular.

1. Ami, Na, Ni, Nga, contracted into M. N.

2. Awo, o

3. Anu

Plural.

1. Awa

2. Ani

3. Alo

Singular.

1. Ami ale

2. Awo ale

3. Anu ale

Plural.

1. Awa ale

2. Âni ale

3. Alo ale

Awa sẹtta awa ayaje Ani setta ani ayajẹ Alọ sẹtta alọ ayaje

\section{COMPARISONS OF ORU AND BRASS, OR ITEBU.}

English.

Water

Fire

Firewood

Mat

God
Oru.

Megi

Feni

Fendia

Ute

Orisha
Brass or Itebu.

Migi

Fendi

Fingia

Ute

Orisha 


\section{NOMENCLATURE OR TERMIINOLOGY.}

Eyọ or Yoruba is called Aku in Sierra Leone from salutation.

\begin{tabular}{|c|c|c|c|c|}
\hline$"$ & " & Ayaji & by the & Nupe \\
\hline$"$ & " & Yariba & & Haussa \\
\hline$"$ & $"$ & Anagonu & or Inago & " Рopọ \\
\hline$"$ & " & Ayọnu & by the & Dahomey \\
\hline
\end{tabular}

Nupe is called Tapa or Takpa by the Yoruba

Pọpo

Daliomey

" Egùn by the

Lgun by the "

" Dada "

Igbira and neighbouring ) countries is called

Kotokori

Koto

Kakanda

Bunu

Shabe

99

")

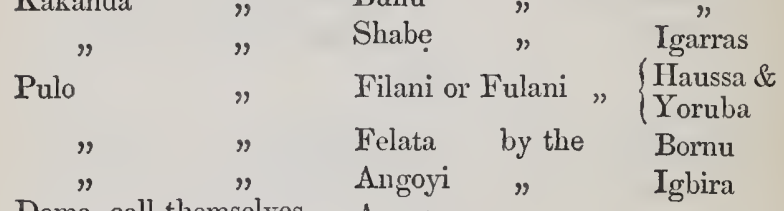

Doma, call themselves Arrgo

Djukù or Baibai of

Kororofa is called

\}Apa or Akpa by the Igarra

Djuku \& Mitshi are called Akpa or Apa ” Ibo

Zhibu or Filani, slaves

there are called

Katshara

Gannako

Gandiko

$"$

Muri or Hamaruwa ,

Oru

Abọ or Aboh ",

"

Bonny, properly Obani „, Okolobà

Brass, properly Nempe „Itebu

Calabar, properly Efik „ Kalaban

Kundi

Ijọ or Ojọ

Oru 
Shekiri are called Iwini by the Ibo. Ado Ido or Idu " $\mathrm{Opu}$ " Igarra and all the countries up the river.

Haussa is called Abakna by the Igbira, Doma, Kororofa, and other countries up the river.

10. The Time of the Day.

English. Haussa. Pulo. Yoruba.

$\left.\begin{array}{ll}\text { Cock-crowing } & \text { Asuba } \\ \text { Morning } & \text { Dasafe }\end{array}\right\}$ Fajiri $\quad\left\{\begin{array}{l}\text { Afẹmojumo } \\ \text { Kùtukutu }\end{array}\right.$

About 8. A.M. Anthin Luha, Woluha Owurò

"12. A.M. Rana sakka Najetshaka Ossangangan

" 2. P M. Azahar Zura Ayila

" 4. P.м. La Aser Alazara Așale

Sunset Almurù Magaribà Orunwc

About 8. P. M. Lisha Eshai Alle 


\section{APPENDIX III.}

1. Route to Yola from Hamaruwa.

Hamaruwa

1. Zhirù

2. Erima

3. Zongo nkawo

4. Akam

5. Zongo nkangi

6. Gangume

7. Zongo ndoka

8. Kogi mbaba

9. Zhan garigari 14. Yola

10. Kwantshà

'The first five stages belong to Hamaruwa territory.

The remaining nime belong to Adamawa. This route of 14. days' journey is made round the Fumbina mountains by traders from Bantshi, Kano, and Katshina from the Haussa country, who trade in slaves and ivory, the road being safe under the government of the Filaris.

2. Route to Yola by the course of the Binue.

Hamaruwa

1. Wurobeli

2. Gowoi

3. Zena.
4. Tahiri subject to Lawal.

5. Wuro Alahaji, only a short distance to Yola

The Zenas are independent, and hostile to the Filanis: travellers who venture by this route must pass Zena in the night to avoid the attack of the pagans by day. Wurobeli and Gowoi are subject to Hamaruwa.

From Gandiko to Yola 15 days' journey

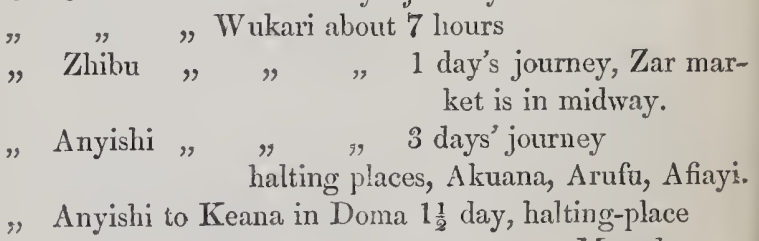
Magede. 
From Kwata on the left of the Binue to Wukari 2 days. "Zhibu to Gomkoi on the left of the Binue, 5 days. " " Nyindo " " 5 days.

The Filanis were about to attack this place this dry season, one of them applied to me for a charm to enable him to catch slaves at Nyindo.

The following places were given, as being between Zhibu and the Confluence of the Binte and Faro or Paro, Zliibu, Belal, Djandurode, Kafe (chief Erina), Hama or Hamaruwa, Batshama, Bula, Dampsa, Garin, Tambul, Kenmi, Adamawa, Bunda at the Confluence of Binue and Paro or Faro.

3. Route to Doma by Ojogo on the right of the Binue.

Ojogo, Tunga, (a small village), Keana (large town), Kunduku, and Kalashi, (both small), Giza (large), Kireyi (small), Kodoroko (large), Kowara (small), Doma (large).

\section{Route from Rabla or Lade to Albeoliuta.} Rabba, Gulufu, Saraji, Budo Alla Sariki.
Lade, Lafiaji, Sambufu, Budo Alla Sariki. Oke-Oyi, Ilori, Aimayọ̀, Ojoku, Inisà, 'Ikiron, Oșogbo, Eddẹ of 'Timi, Iwo-Isalle, Ijèhanna, 'Ibadan Ilugun, Oke Żoko, Abbẹokuta.

Though Maliamma, the Yoruba traveller who is at present residing at the Confluence of the Kowara and T'shadda, in pursuit of his charm making trade, has made eigliteen easy days' journey of this route, he said it could be aceomplished in twelve days' hard pusl, if no linderance took place on the way. 
5. Names of the Kowara and Tshadda.

The Kowara is called Fari nrua (the white water) in general. The Tshadda " Baiki nruwa (the black water) in general.

\begin{tabular}{|c|c|c|}
\hline$"$ & " & Niluu or Lihu by the Igbira. \\
\hline$"$ & " & $\mathrm{Nu} \quad, \quad$ Djuku. \\
\hline & $"$ & Binue $\quad$, Djuku and Filani. \\
\hline The Niger & " & $\begin{array}{l}\text { Osimirin by the Abo and the people } \\
\text { of the Delta. }\end{array}$ \\
\hline
\end{tabular}

6. States governed by the Filunis, according to Ibratim, our guide at Hamaruwa.

States.

1. Bagarmi

2. Adamawa

3. Hamaruwa

4. Gòmbe

5. Bornu

6. Shira

7. Katagu

8. Marma

9. Hadeji

10. Awoyò

11. Kano

12. Kasawurai

13. Dawura

14. Katshina

15. Zanfara
Names of Governor.

Sariki Bagarmi.

Lawal (Loèl of Dr. B.)

Mohamma.

Koiranga.

Sumanu.

Abduramanì.

Dankaowà.

Mahımma.

Bohari.

Sambò.

Sumanu.

Dembo.

Zuheirù.

Mohamma Bello.

Mamudu. 
16. Gobiri

17. Bautshi

18. Zozo (Zegzeg)

19. Dawudù

20. Nufe, or Nupe

21. Ilorin

22. Yawuri

23. Kiabi.
Ali.

Tbrahima.

Sidi.

Badja.

Dasaba.

Abdusalami.

Sariki n Yawuri.

Sariki n Kabi.

Sokoto, the seat of government, and Alihù Sariki n Musulmin, or the sovereign of the faithful. Of these states, some are very extensive, and others small. Among the extensive states may be classed Adamawa, as far, according to Ibrahima, as to Igarra, and he believes that the Atta pays tribute to Lawal of Yola, through some intermediate channel. The state of Hamaruwa comprises all the countries on the banks of the Binue from Bautshi, including a part of Kororofa, of which Wukari is the capital, which however, pays tribute to Bautshi.

Samuel Crowther. 


\section{NOTE BY DR. WILLIAM BLEEK.}

\section{(To page 205)}

It is a mistake of Mr. Samuel Crowther's that his Nitshi Vocabulary gives us a totally unknown language. At the first look upon Kölle's Polyglotta Africana, I saw that here the Tíwi (XII. E. 19) shows only very slight dialectical differences. And in Kölle's Introductory Remarks, he says :-Tíwi, called Mîdși, or Mbidși, by the Kurórofas and Haussas, and Gbâlon by the Agâyas, who speak the same language as the Tíwis. Herewith agrees Crowther's notice that the Djuku and Mitshi are called $\Lambda$ kpa or Apa by the Ibu. Likewise indeed the 1)jukù, or Barbai of Kororofa, are called Apa or Akpa by the Igbarra. Kölle's work is indeed an immense store of African knowledge, and its use would be still greater, if good indices were added of all the names of Languages, Nations, Countries, and places to be met with in his Introductory Remarks.

Still Mr. Crowther's Vocabularies are most important enlargements; as Vocabularies, \&c., made on the spot, are always preferable to such as are taken from individuals in places distant from their homes. 

18 




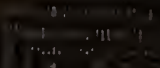

(1) 14 the

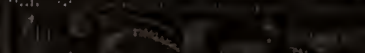

1.4. 4

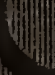

